Portland State University

PDXScholar

\title{
Utterly visionary and chimerical : A federal response to the depression : an examination of Civilian Conservation Corps construction on National Forest System lands in the Pacific Northwest
}

\author{
Elizabeth Gail Throop \\ Portland State University
}

Follow this and additional works at: https://pdxscholar.library.pdx.edu/open_access_etds

Part of the Labor History Commons, and the United States History Commons Let us know how access to this document benefits you.

\section{Recommended Citation}

Throop, Elizabeth Gail, "Utterly visionary and chimerical : A federal response to the depression : an examination of Civilian Conservation Corps construction on National Forest System lands in the Pacific Northwest" (1979). Dissertations and Theses. Paper 2935.

https://doi.org/10.15760/etd.2928

This Thesis is brought to you for free and open access. It has been accepted for inclusion in Dissertations and Theses by an authorized administrator of PDXScholar. Please contact us if we can make this document more accessible: pdxscholar@pdx.edu. 
AN ABSTRACT OF THE THESIS OF Elizabeth Gail Throop for the Master of Arts in History presented July 27, 1979.

Title: Utterly Visionary And Chimerical: A Federal Response To The Depression. An Examination of Civilian Conservation Corps Construction On National Forest System Lands In The Pacific Northwest.

APPROVED BY MEMBERS OF THE THESIS COMMITTEE:

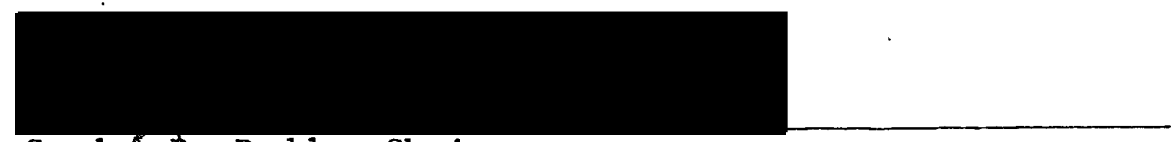
Gordof 3 . Dodds, Chairman

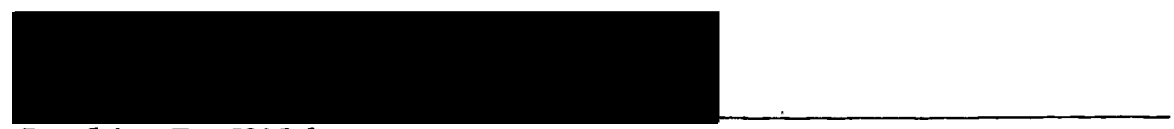

Leslie E. Wildesen

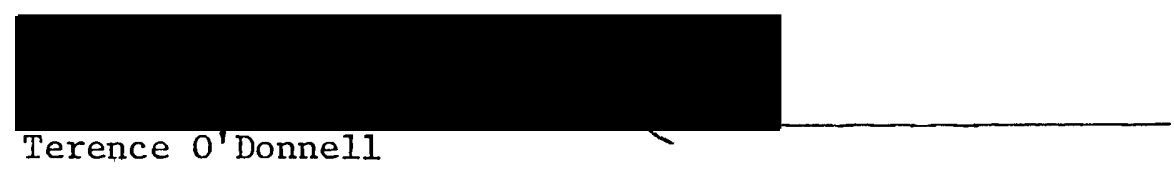

The federal response of President Franklin D. Roosevelt's administration to the economic crisis of the Depression was experimental and unprecedented. Depressions and financial panics were not new phenomena, but the Depression of the $1930^{\prime} \mathrm{s}$, compounded by international economic collapse and disastrous drought in the nation's major agricultural areas, permeated every component of American society, and failed to respond to traditional recovery measures. 
Emergency Conservation Work was the first significant New Deal relief measure, passed by Congress on March 31, 1933. This act created the Civilian Conservation Corps which, over the nine years of its existence, employed almost three million youths, local experienced men, veterans, Indians and territorials in useful conservation work nationally. - Under the supervision of the U. S. Forest Service, "C' $s$ " from all parts of the nation constructed or improved recreational sites and administrative facilities on National Forest lands.

In partial fulfillment of its responsibilities under Executive Order 11593, the Forest Service has undertaken an inventory of extant Depression era sites and structures, in Oregon and Washington as historical cultural resources. The purpose of the inventory was to 1ocate, identify, describe and record the physical entities produced by these historical human activities. Evaluation of their qualities of significance in history and architecture succeeded the inventory process. Assessment of the importance of the Depression-era properties involved the measurement of each against the criteria of the National Register of Historic Places.

Both inventory and evaluation were based on extensive research utilizing the surviving Forest records of that period, Handbooks, reports, directives and guidelines of the U. S. Forest Service, of both regional and Washington offices, as primary source materials. The use of secondary sources pertinent to the Depression era, the Roosevelt administration, the New Deal programs and the Civilian Conservation Corps provided the appropriate historical perspective. Photographic records, both historic and contemporary, were utilized to 
advantage in describing structures and in assessing their integrity. Personal on-site observation was necessary and of inestimable value. The inventory process, although not yet completed, has identified approximately one thousand sites and structures built by the Civilian Conservation Corps remaining on National Forest lands in Oregon and Washington. Architectural descriptions are contained in Appendix A; their geographical distribution is noted on maps in Appendix B. Sufficient numbers and categories have been recorded to establish a valid representative sample and to justify the conclusions of the evaluation process.

The activities of the Civilian Conservation Corps on these National Forest lands were of importance in Pacific Northwest history. The fire prevention and suppression and timber stand improvement projects assured a continuing source of timber supply for the major areal industry; the range improvement and soil conservation projects stabilized a vital forage resource for the stockraising industries; the construction of CCC camps and the forest improvement projects required incalculable quantities of milled lumber and wood products which bolstered the seriously depressed lumber industry. The Civilian Conservation Corps provided employment for many local men, both juniors and experienced craftsmen, and a measure of financial relief for their families. The rustic architecture of the Depression-era structures represents an uniquely American design philosophy. Its non-intrusive expression utilized natural and native materials, and, being labor-intensive, was ideally suited to the aims of the Civilian Conservation Corps. 
Most of the surviving Depression-era sites and structures meet the criteria of the National Register of Historic Places and as eligible properties will be nominated for inclusion. They will be appropriately maintained to conserve their historic integrity and to protect their identified values. Recommended management alternatives include continued like use, adaptive reuse and rehabilitation. Interpretation for public enjoyment is encouraged. 
UTTERLY VISIONARY AND CHIMERICAL: A

FEDERAL RESPONSE TO THE DEPRESSION

AN EXAMINATION OF CIVILIAN CONSERVATION CORPS CONSTRUCTION ON NATIONAL FOREST

SYSTEM LANDS IN THE PACIFIC NORTHWEST

by

ELIZABETH GAIL THROOP

A thesis submitted in partial fulfillment of the requirements for the degree of

MASTER OF ARTS

in

HISTORY

Portland State University

1979 
TO THE OFFICE OF GRADUATE STUDIES AND RESEARCH:

The members of the Committee approve the thesis of

Elizabeth Gail Throop presented July 27, 1979.

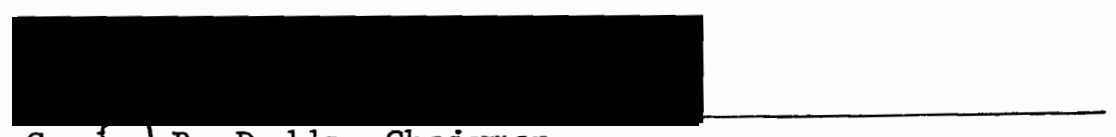

Gordon B. Dodds, Chairman

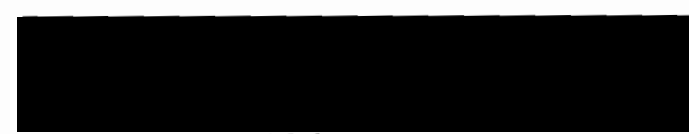

Leslie E. Wildesen

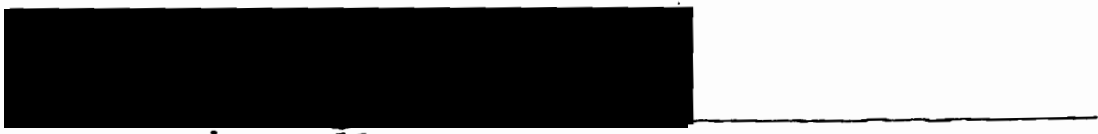

Terence 0'Donnell

APPROVED :

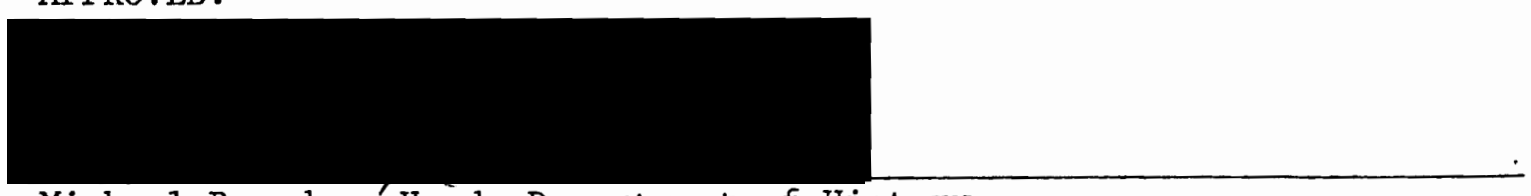

Michael Reardon, Head, Department of History

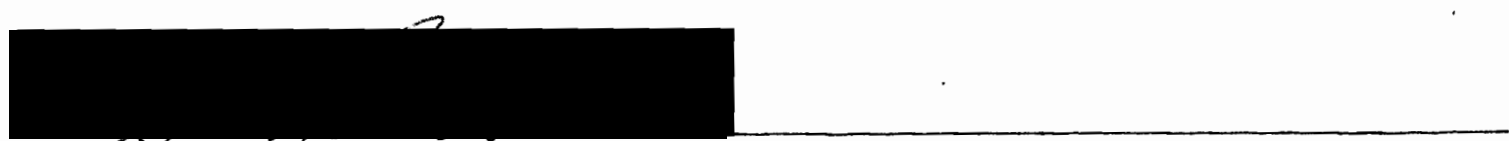

Stanley Rauch? Dean of Graduate Studies and Research 


\section{PREFACE AND - ACKNOWLEDGMENTS}

In fulfillment of the internship requirement of the Public History Program for the degree of Master of Arts in History, the author was employed as Historian, Division of Recreation, Regiona1 Office, U. S. Forest Service, Pacific Northwest Region, for the period of the 1978-79 academic year. The examination of the Civilian Conservation Corps construction in the Pacific Northwest was undertaken as a project in furtherance of the Cultural Resources Management Program, as mandated by the National Historic Preservation Act of 1966, and Executive Order 11593 (1971).

The principal purpose of this study was to discover what tangible evidence remains of the Civilian Conservation Corps construction projects undertaken on the National Forest System lands in the Pacific Northwest Region: to identify, locate, describe and evaluate these historic cultural resources and to ascribe some significance to them. It should be noted that all references to National Forests and to Ranger Districts are to current administrative jurisdictions, unless otherwise specified, for reasons of convenience.

To identify and locate the Depression-era sites and structures, the nineteen National Forests of Region Six (Oregon and Washington inclusive) were asked to submit informal inventories of their known properties. In compiling these lists, building maintenance and Forest improvement records were reviewed and knowledgeable Forest personnel 
were consulted. Maps locating the identified properties were requested. Eighteen National Forests responded to these requests, although not all Ranger Districts were included in the responses.

From this information, the scope of the resource base was determined. Classifications and categories of resources were devised and the density of each recorded. Maps indicating the approximate locations, the distribution and density of administrative and recreational sites and of community kitchens are found in Appendix B. Over 1,000 sites and structures constructed by the Civilian Conservation Corps in the Pacific Northwest remain as evidence of one New Deal response to the Depression, and as proof that the CCC was not the "utterly visionary and chimerical" concept that Hoover's Secretary of Agriculture Arthur M. Hyde derided.

Description of each site and structure was accomplished with the aid of current photographs taken by designated personnel on each responsive District of each Forest. Each structure was described in architectural terms of reference, with obvious structural and material alterations to the exterior noted. The building descriptions, together with the corroborative historical data obtained from the initial inventory comprise the quantitative data base from which the evaluations were drawn, and are found in Appendix A. Those sites and structures described represent the total photographic response as of July $1,1979$.

Personal on-site examination of the identified sites and structures, to the extent possible, and comparison of their present appearance with their appearance in contemporary photographs assisted in the 
evaluation process. Examination of historic handbooks, directives and guidelines revealed the extent of the planning process. Reports, regulations, and project work records defined the roles of the Forest Service and its component parts, and the roles of the project supervisors, the crew foremen, the technicians, the LEMs and the CCC enrollees, and established their relationships to the projects. Reference to other Forest records and reports and discussions with knowledgeable Forest personnel made possible the description of the various kinds of structures and sites--their intents and purposes and the rationale for their existence. It was imperative to discuss their values to the National Forest System and more particularly their import to the region and its residents. Finally, it was necessary to identify their place in the whole of federal response to the Depression. 'Documentary evidence specific to the Civilian Conservation Corps projects in the Pacific Northwest is dispersed and in many cases nonexistent. To satisfactorily exhaust all research possibilities would take much more time than that allotted to this project by the Forest Service. Therefore, it is a preliminary inventory only, and analysis and interpretation must be based on a representative sample, upon extrapolation. The representative sample was developed from the photographic response. When compared to the initial inventory, the number of actual sites and structures described and evaluated represents perhaps eighty-five per cent of the total, with characteristic examples of each classification and category included.

To make the inventory and evaluation of the Depression-era sites and structures of value to the Forest Service, beyond compliance with 
statutes and implementing regulations, an interim regional management plan is being developed. This will be integrated in more permanent form in the projected Integrated Facilities Management Plan for Region Six.

Completion of the study would not have been possible without the interest and cooperation of the Forest Supervisors and District Rangers who administer the National Forest System lands and their natural and cultural resources. Without the assistance of the Forest Cultural Resource Specialists and Cultural Resources coordinators, fulfillment of the project goals would not have been achieved. It would be gross ingratitude not to acknowledge the efforts of the secretaries and typists of the Division of Recreation, Regional Office: their help was invaluable.

Particular acknowledgment must be made of the generous insights and ideas of Edward T. Cobo, of the Rogue River National Forest. Under his tutelage and guidance, a clearer perception of Cultural Resources Management emerged. Special thanks is due to Leslie E. Wildesen, Gordon B. Dodds, and Terence O'Donnell for their considerate counsel and constructive criticism.

Especial appreciation is expressed to Gerald Joseph Throop whose support and encouragement made possible the pursuit of academic achievement and professional competence. His sustained enthusiasm and enduring patience made this extended study enjoyable and productive. 


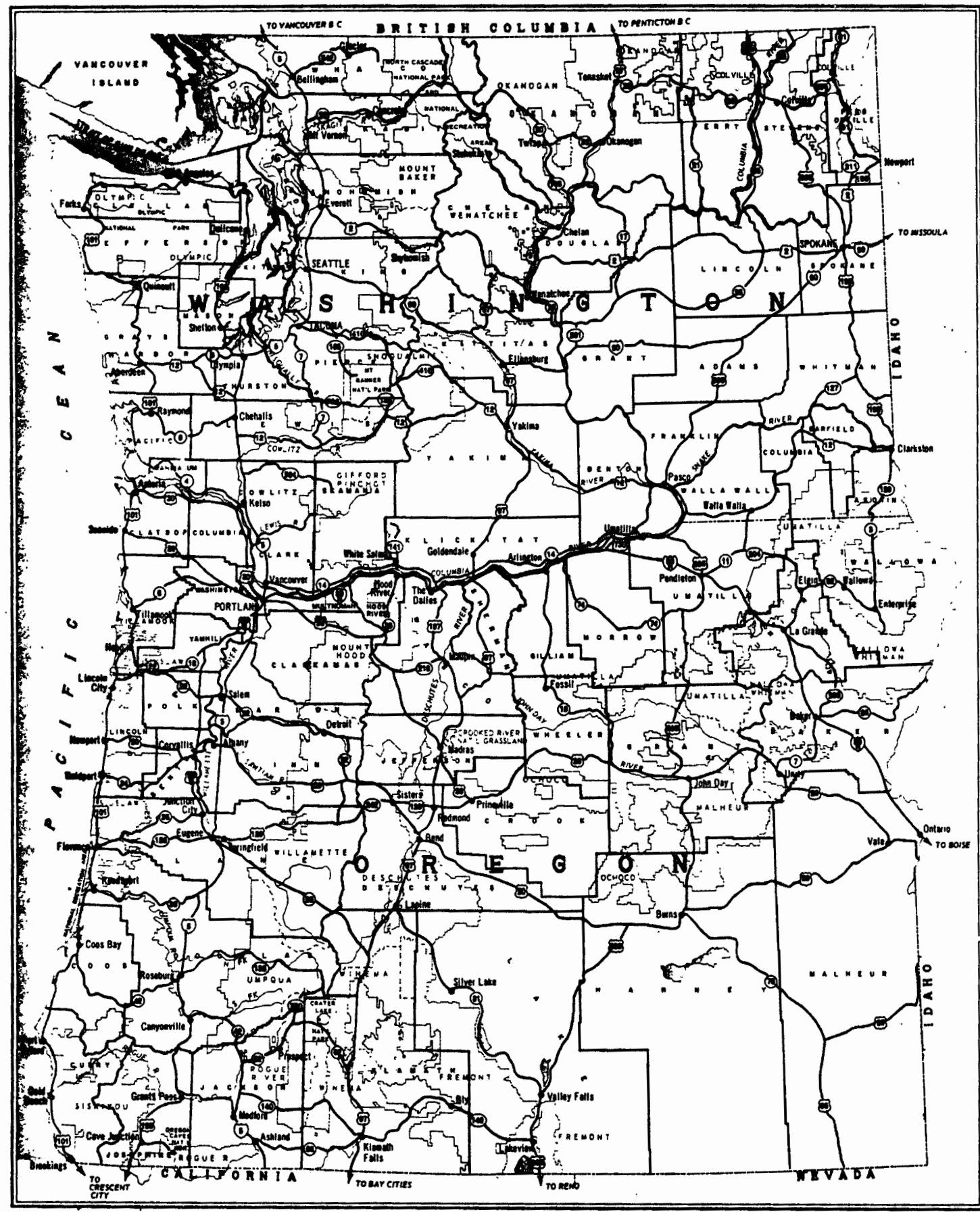

U.S. DEPARTMENT OF AGRICULTURE FOAEST SERVICE

NATIONAL FORESTS

OF THE
PACIFIC NORTHWEST REGION

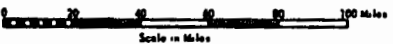

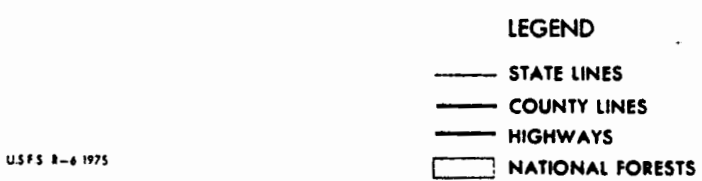


TABLE OF CONTENTS

PAGE

PREFACE AND ACKNOWLEDGMENTS . . . . . . . . . . . .

LIST OF FIGURES

CHAPTER

I INTRODUCTION THE GREAT DEPRESSION . . . . . . 1

II THE CIVILIAN CONSERVATION CORPS ........ . 6

Organization and operation ........ 10

Activities In The Pacific Northwest . . . . 21

III FOREST IMPROVEMENTS .............. . . 27

Administrative Sites and Structures . . . 29

Planning and Design

Site Locations

Site Development Plans

Landscape Planning

Administrative Rustic Architecture . . . .

Region Six Architectural Style

Recreation Sites and Structures ......

Planning and Design

Recreational Rustic Architecture . . . . . 54

IV EVALUATION ........................... 65

V MANAGEMENT ........................... 75

VI CONCLUSION ......................... 81 
PAGE

BIBLIOGRAPHY

APPENDIX A

APPENDIX B . . . . . . . . . . . . . . . . . . .

APPENDIX C . . . . . . . . . . . . . . . . . . . . 


\section{LIST OF FIGURES}

FIGURE

PAGE

1. National Forests of the Pacific Northwest Region

vii

2. Detail - Pine Tree Cut-out Specifications

3. Geographical Distribution of Depression-era Administrative Sites - Oregon

4. Geographical Distribution of Depression-era Administrative Sites - Washington

5. Geographical Distribution of Depression-era Recreation Sites - Oregon

6. Geographical Distribution of Depression-era Recreation Sites - Washington

7. Geographical Distribution of Depression-era Community Kitchens - Oregon

8. Geographical Distribution of Depression-era Community Kitchens - Washington

9. Three Room Office and Public Toilets, Plan No. 116

10. Machine Shop, Plan No. 701

11. Fire Equipment Warehouse, P1an No. 623

12. Gas and Oil Storage, Plan No. 543

13. Twelve Horse Barn, P1an No. 804

14. Eight Man Crew House, Plan No. 402

15. Seven Room Residence, Plan No. 228

16. Four Room Residence, Plan No. 328

17. Two Room Guard Cabin, Plan No. 312-A

18. Public Comfort Station, Plan No. 923 
19. Detail for Overlook Shelter, P1ate 12-G

20. Playground Facilities, Plate $19 \mathrm{H}$

21. Garbage Disposa1, Plate 5

22. Rustic Fences and Barricades, Plate $18 \mathrm{~A}$

23. Left Side Elevation, Gas and Oil Storage; Rager Ranger Station, Ochoco National Forest

24. Right Side Elevation, Gas and Oil Storage, Rager Ranger Station, Ochoco National Forest 
CHAPTER I

\section{INTRODUCTION}

\section{THE GREAT DEPRESSION}

October 29, 1929, "Black Thursday," marks the beginning of the Great Depression in the public mind. Although it did not cause the Depression, the stock market collapse did precipitate the economic crisis by "replacing the inflationary spiral with a deflationary one equally hard to stop."1

Economic depression was not a new phenomenon: financial panics, recessions and depressions dotted the historic economic landscape, occurring with almost cyclical regularity. Previous catastrophes had overtaken a predominantly agricultural society, relatively insulated from international complication by Its isolation; the Great Depression, compounded by international economic collapse, found a predominantly urban and industrialized society, with substantial blocks of its productive agricultural land withered and driven by drought and wind, or exhausted and eroded. Permeation of all facets of the economy was rapid and complete.

The causes of the Depression seemed less important to the people who became victims than its effects. The stock market crash had ruined

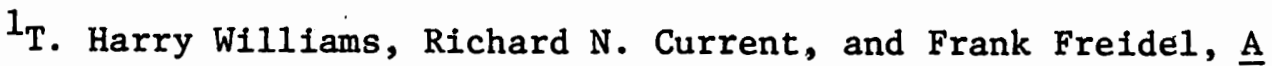
History of the United States (Since 1865). (New York: Alfred A. Knopf, 1960), p. 464 . 
many investors, and erased holding company and investment trust structures. It had destroyed an important source of long-term capital and sharply cut back consumer demand, and it had shattered business confidence. The ensuing failure of the banks utterly demolished public morale. ${ }^{2}$

Far more energetic and imaginative than any previous American president in trying to alleviate an economic crisis, Herbert Hoover determined that the Federal government should intervene positively but in a very limited way, seeking the voluntary cooperation of business and labor. The government would also fight deflation through a significant tax cut, liberal credit for business through the Federal Reserve, stabilized farm prices through the Farm Board, and increased public work appropriations. Beyond this, Hoover stood for a balanced budget and sound money. ${ }^{3}$

But the economy sank lower and lower. Security and commodity prices collapsed; bankruptcies and bank failures multiplied; unemployment soared. Finding that voluntary measures were insufficient to combat the depression, Hoover proposed direct governmental action of an unprecedented sort: (1) establishment of a federal loan agency like the War Finance Corporation; (2) additional credit for farmers faced with foreclosure; (3) reform of the banking system to safeguard deposits; (4) reform of bankruptcy laws to aid in the speedy reorganiza-

2William E. Leuchtenburg, The Perils of Prosperity, 1914-1932, (Chicago: University of Chicago Press, 1958), p. 247.

${ }^{3}$ Williams, Current, and Freidel, A History of the United States p. 465 . 
tion of business and the settlement of overwhelming debts; (5) the loan of $\$ 300$ million to states for direct relief; (6) further expansion of public works; (7) drastic economy in the Federal government. 4

Thousands of Americans were introduced to a new and humiliating way of life on the relief rolls. Unemployment respected no economic or social class. Millions who had never been unemployed were now jobless and unable to find work of any sort. old traditions of self-reliance and rugged individualism had to be abandoned: it was no longer true that opportunities were limitless if only one had the ambition and energy to take advantage of them. With the greatest reluctance, with savings gone, credit exhausted, work unobtainable, and with families to provide for, they had to subdue their pride and face reality. There were no alternatives. They had resisted as long as they could because anything was better than the dole, "a word invested with every ominous significance." 5

President Hoover was not unsympathetic, but his concept of government precluded direct federal relief. He strongly believed that if America meant anything, it meant the principles of individual and local responsibility and mutual self-help. "If we start appropriations of this character, we have not only impaired something infinitely valuable in the life of the American people but have struck at the

4ibid., p. 467.

${ }^{5}$ Arthur M. Schlesinger, Jr., The Age of Roosevelt, Vo1. 1: The Crisis of the 01d Order, 1919-1933, (Boston: Houghton Miffin Company, 1957), pp. 169, 179. 
roots of self-government." 6 For many years a popular American hero, Hoover became the scapegoat for the depression.

The very word "Hoover" became a disparaging prefix. "Hoovervilles" were towns of tar paper and tin, old packing boxes and old car bodies along railroad embankments, in the city dumps, anywhere unoccupied land could be found. There were also "Hoover blankets" (newspapers wrapped around for warmth), "Hoover wagons" (broken down automobiles hauled by mules), "Hoover flags" (empty pockets turned inside out), and "Hoover hogs" (jackrabbits). The bed of an abandoned reservoir in Central Park became "Hoover Valley". Latrines dug at the Bonus Expeditionary Force's encampment at Anacostia Flats were known as "Hoover Villas."

Yet despite the rancor and restlessness, the desperate want in the midst of overabundance, the predominant mood after the third winter of depression was less one of revolt than of apathy. In The Crisis of the O1d Order, 1919-1933, Arthur M. Schlesinger, Jr., aptly described the nation's disposition:

Too much had happened too quickly to too many for the implications to be fully absorbed. . People were sullen rather than violent. Instead of fuming with resentment and rushing to the barricades, they sat at home, rocked dispiritedly in their chairs, and blamed "conditions." 8

Nineteen-thirty-two was a presidential election year, and the Democrats chose as their candidate Franklin D. Roosevelt. Dynamic,

$$
\begin{aligned}
& { }^{6} \text { Ibid., p. } 170 . \\
& { }^{7} \text { Ibid., pp. } 245,250,259 . \\
& { }^{8} \text { Ibid., p. } 252 .
\end{aligned}
$$


vigorous and decisive, he campaigned with fervor on the issues confronting the nation. His basic policies did not really differ substantially from those of the Hoover administration nor did his fundamentally conservative approach to government, but his philosophy of leadership offered a striking contrast. Convincing the people that he would mobilize the power of the government to help them, Roosevelt made an impression which Hoover had never been able to create. By instilling hope and courage, he made one of the greatest contributions to the politics of the 1930 's. 9

In his first Inaugural Address, President Franklin D. Roosevelt asserted that he would go to Congress with a plan of action, but if Congress did not act and the emergency persisted:

I shall not evade the clear course of duty that will then confront me. I shall ask the Congress for the one remaining instrument to meet the crisis--broad Executive power to wage a war against the emergency, as great as the power that would be given to me if we were in fact invaded by a foreign foe. 10

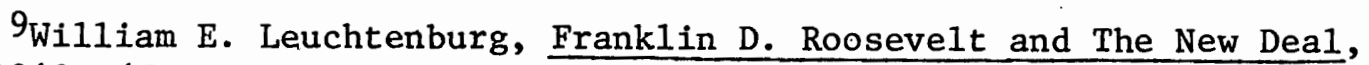
1932-1940, (New York: Harper and Row, Harper Colophon Edition, 1963), p. 42 .

10 Franklin D. Rooseve1t, First Inaugural Address, cited by Leuchtenburg, Franklin D. Roosevelt and The New Deal, 1932-1940 (New. York: Harper and Row, 1963), p. 41. 
CHAPTER II

THE CIVILIAN CONSERVATION CORPS

The Great Depression extended its grip to all sectors of the American population. Unable to find work in their home environments, almost two million men and women adopted a vagrant existence, with no fixed destination or appointed schedule. Among them were nearly 250,000 young people between the ages of fifteen and twenty-four. With nothing to do and little to hope for, they rode the rails, thumbed rides, or walked, "bewildered, sometimes angry, but more often hopeless and apathetic."11 Many more similarly jobless youths never left home. Untrained, unskilled, and unable to obtain the necessary experience, they were singularly unqualified for placement in a nonexistent job market.

At the same time, the nation faced the consequences of three generations of exploitation and ill-usage of its natural resources. Land-use ethics governed by economic self-interest had resulted in exhausted soil, denuded forests and over-grazed grasslands. The failure to replace the lost elements had resulted in increasing erosion by wind and water, and in the continuing threat to remaining resources.

11John A. Salmond, The Civilian Conservation Corps, 1933-1942: A New Deal Case Study, (Durham, North Carolina: Duke University Press, 1967), p. 4 . 
Secretary of Agriculture Henry A. Wallace graphically and succinctly described the state of the nation's natural resources:

Thoughtlessly we have destroyed or wounded a considerable part of our common wealth in this country. We have ripped open and to some extent devitalized more than half of all the land in the United States. We have slashed down forests and loosed floods upon ourselves. We have torn up grasslands and left the earth to blow away.

We have built great reservoirs and power plants and let them be crippled with silt and debris, long before they have been paid for. 12

John D. Salmond, in The Conservation Corps, 1933-1942, suggests a number of possible origins for the concept of the CCC, among them William James' 1912 essay, "The Moral Equivalent of War," programs of local relief work in the forests begun on a limited scale in various parts of the United States, and examples of conservation camps in many European countries, most particularly, in Germany. He observed, "Though one can indeed find a wide variety of possible sources for the idea of the CCC, it nevertheless remains true that more than any other New Deal agency it bore the personal stamp of President Roosevelt."13 In implementing New York's unemployment relief program in 1932 , then Governor Roosevelt had incorporated the reforestation of state lands, providing temporary employment for 10,000 people previously on the relief rolls.

of a family and social class steeped in the philosophy of the Hudson River School, and in the tenets propounded by Emerson and

12 Henry A. Wa1lace, 1940, as cited by J. J. McEntee, Federal Security Agency Final Report of the Director of the Civilian Conservation Corps, (typescript, copy, no date), p. 41.

${ }^{13}$ Salmond, The Civilian Conservation Corps, pp. 4-6. 
Thoreau, Franklin D. Roosevelt was inclined, from an early age, to espouse the spiritual and physical values inherent in Nature. At the same time, he was exposed to the doctrines of conservation, developing the long-held conviction that conservation of the nation's natural resources was essential to continued progress. The idea of the Civilian Conservation Corps embodied these two fundamental beliefs. The Corps would act as a catalyst, bringing together two wasting national assets, natural resources and idle young men, in an attempt to reclaim both.

The first suggestion of a national conservation plan emerged in Roosevelt's acceptance speech at the Democratic Convention in Chicago, July 2, 1932. He called for a "definite land policy" to fight "a future of soil erosion and timber famine." "In so doing, employment can be given to a million men. That is the kind of public work that is selfsustaining. Yes, I have a very definite program for providing employment by that means." Here in generalized form, was the idea of the Civilian Conservation Corps. 14

Although the reforestation - employment plan was attacked derisively by President Hoover's Secretary of Agriculture, Arthur M. Hyde, professional foresters and conservationists were initially enthusiastic. But without elaboration of the plan, or any clarification of its mechanics, many began to doubt the practicality and even the feasibility of such a large scale program. ${ }^{15}$

\footnotetext{
14 Ibid., p. 8. 15Ibid., p. 8 .
} 
Roosevelt did not directly approach the Forest Service until midNovember, 1932; at that time, the Chief Forester, Major Robert Y. Stuart, was instructed to develop plans for the employment of 25,000 men in the federally owned forests. Having recently completed a survey of urgently needed work, sufficient information was available to indicate where camps could most profitably be established, but much more was needed to develop a comprehensive plan that would include state forests. 16

Further development of the work relief scheme was not pursued until March 9, 1933, when Roosevelt outlined the details of his plan to a conference attended by the Secretaries of Agriculture, Henry Wallace, Interior, Harold L. Ickes, and War, George Dern, the Director of the Budget, Lewis W. Douglas, the Army Judge Advocate-General, Colonel Kyle Rucker, and the Solicitor of the Department of the Interior, Edward Finney. 17

On March 21, 1933, the President's message on the "Relief of Unemployment" went to Congress accompanied by identical bills for "The Relief of Unemployment Through the Performance of Useful Public Work and for Other Purposes" which, if enacted, would authorize the President to create a civilian conservation corps from the unemployed to be used on public works projects such as reforestation, prevention of soil erosion and of floods. An enrollment period of one year was provided

16Ibid., p. 9.

17 McEntee, Final Report, p. 1. 
for, with no discharge during this period without permission, and a $\$ 30$ per month pay limit. ${ }^{18}$

Although reservations were expressed regarding militarization of the work force under Army supervision and increasing tendency to concentrate power in the Executive, debate was primarily focused on labor and wage questions. However, given the emergency nature of the legislation, and the lack of feasible-alternatives, support was substantial and the measure passed on March 31, 1933, with only two significant amendments: (1) that conservation projects would extend to State lands; and (2) that no discrimination would be made on account of race, color or creed. The agency created by the Act was officially called Emergency Conservation Work (ECW), but the name Civilian Conservation Corps as used by the President in his March 21 message to Congress quickly supplanted the official title. 19

\section{ORGANIZATION AND OPERATION}

At a White House conference on April 3, Roosevelt formally defined the positions of the cooperating agencies and outlined the tasks of each. The Department of Labor was directed to select the men for enrollment; the War Department was to enroll the men, feed, clothe, house, and condition them, and transport them to the camps; the Department of Agriculture and Interior, through their various bureaus, were to

${ }^{18}$ Salmond, The Civilian Conservation Corps, pp. 12-13.

${ }^{19}$ Ibid., pp. 14-25, 26. Salmond notes that there was no statutory CCC until June 28, 1937, when it was created by the Act of Congress. 
Select work projects, to supervise the work, and to administer the camps. The Director of Emergency Conservation Work was to develop policy, issue . the basic operational directives and coordinate the work of the four Departments. This design of organization and delineation of functions remained almost unaltered until the Civilian Conservation Corps was terminated in 1942.20

Following the April 3 conference, the General Staff drafted complete regulations governing the Army's role in the establishment and maintenance of the Corps. The country was divided into nine Corps areas, and provisions were made for clothing, food, shelter, supervision, welfare and transportation.

The Department of Labor, responsible for the selection of the workforce and having no nationwide organization, determined to utilize existing state and local relief agencies through the United States Employment Service, directed by W. Frank Persons. State Directors of Selection were appointed to coordinate the agencies' activities. Selection of young unmarried men between the ages of seventeen and twenty-three, who were unemployed and in need of work, and whose families were on Relief Rolls, was to be made on a state quota basis in proportion to population. ${ }^{21}$

Based in part on the recently completed forest work survey, the Forest Service devised operating plans and work schedules. ${ }^{22}$ The

$$
\begin{aligned}
& 20 \text { Ibid., pp } 27-31 . \\
& 21_{\text {Ibid., p. } 27 .} \\
& 22 \text { U. S. Congress, Senate, A National Plan for American Forestry, }
\end{aligned}
$$
Sen. Doc. 12, 73 Cong. 1, March 13, 1933. ("The Copeland Report"). 
Secretary of Agriculture conferred with state authorities in order to implement the extension of the conservation program to' state-owned forest lands.

The National Park Service, in the Department of Interior, also drew up schedules for conservation work in the National Park System, and began work on a program that would include conservation work and construction of facilities in state parks.

The Administration sought a director to administer the Civilian Conservation Corps, eventually appointing Robert Fechner, a widely respected labor leader.

Executive Order 非101, issued by the President on April 5, 1933, established the official existence of the Civilian Conservation Corps, and confirmed Robert Fechner as Director of Emergency Conservation Work. In addition, the order outlined the broad relationship which was to exist between the various cooperating Departments and the office of the Director, authorized the expenditure of funds for necessary services, materials, and foodstuffs and provided for an Advisory Council to the Director of Emergency Conservation Work, to be constituted of appointed representatives of the Secretaries of War, Agriculture, Labor, and the Interior. 23

James J. McEntee of the International Association of Machinists and Charles H. Taylor were named Assistant Directors. ${ }^{24}$ Appointed to

${ }^{23}$ Ibid., p. 31.

${ }^{24}$ McEntee became Director of the Civilian Conservation Corps in 1939, following Robert Fechner's death. 
the Advisory Council as representatives of the varlous Departments were Colone1 Duncan K. Major, Jr., for the War Department; Major Robert Y. Stuart, soon succeeded by Ferdinand A. Silcox, successively Chief Foresters of the U. S. Forest Service, for the Department of Agriculture; Horace M. Albright, Director of the National Park Service for the Department of the Interior; and W. Frank Persons for the Department of Labor. C. W. Bailey was named as the CCC Representative for the Veterans' Administration. 25

Established as a relief agency, Emergency. Conservation Work was to provide employment "strictly limited to works which are not available for public works, "26 and vocational training for that sector of the population which "had' been left out of calculation by most relief agencies." 27

The new organization established to operate the program was unique in governmental administration because not one but several agencies and Departments participated in its operation and administration. By utilizing the personnel and services of established Departments, sound administration from the beginning was assured, and the expenditure of large sums for building a new supply unit and a large administrative staf.f was avoided.

25McEntee, Final Report, p. 6.

26 Memorandum To The President: The Secretaries of War, Interior, Agriculture, and Labor to Roosevelt. March 14, 1933. Edgar B. Nixon, ed. , Franklin D. Roosevelt and Conservation, 1911-1945, Vol. 1: 19111937 (Hyde Park, New York: 1957), p. 142.

27 Testimony of Secretary of Labor, Frances M. Perkins, Unemployment Relief, Joint Hearings, 1933 (p. 3), as cited by Salmond, p. 16. 
The program itself was without national precedent and so there were no guidelines on which to base the policies or operating schedules. To convert an idea into an operating agency required the concerted efforts of the Director and the cooperating Departments. Al1 branches of the Regular Army, the Army Corps Areas, the Field Offices of the various Departments and hundreds of State and local welfare organizations were involved.

The selection of men began on April 7 and the first camp was established in the George Washington National Forest near Luray, Virginia, on April 17. It was named Camp Roosevelt. However, mobilization proceeded more slowly than the President had hoped when he sent his initial message to Congress.

On May 12 the President ordered mobilization to be accelerated appreciably, directing that the entire unit of 250,000 juniors and 25,000 Local Experienced Men (LEMs) be selected and assigned to appropriate CCC camps by no later than July 1, and that 25,000 war veterans be selected and conditioned as rapidly as possible. ${ }^{28}$

The task assigned contemplated the reception by the War Department of an additional 222,000 men by June 7, 1933, at an average daily rate of $8,540 \mathrm{men}$, the complete organization and equipment, including the necessary motor transport, of approximately 1,200 additional company units by June 23, at the rate of 27 per day, and the establishment of approximately 1,300 work camps by July 1, at a rate of 25 per day. 29

Movement of men from point of enrollment to conditioning camps was made largely by regular and special trains. For local movements

$$
\begin{aligned}
& 28 \text { McEntee, Final Report, p. } 9 . \\
& { }^{29} \text { Ibid., p. } 10 .
\end{aligned}
$$


and short trips buses were sometimes used. Movement of work companies to forests was made almost entirely by rail. The greatest movement was from conditioning camps in the east and middle west to forest camps in the far west, particularly in the states of California, Oregon, Washington, Idaho, Montana, Wyoming, Utah and Nevada. The Quartermaster General's office in the War Department arranged for the use of 211 special trains in the transportation of 55,130 young men from eastern cities to the far west. 30

The entrance of veterans into the Civilian Conservation Corps was made possible through an Executive Order issued by the President on May 23 following conferences between CCC Director Robert Fechner and General Frank T. Hines of the Veterans' Administration. ${ }^{31}$

On the recommendation of the Office of Indian Affairs of the Department of the Interior, the President also authorized the enrollment of 10,000 Indians, this group to live and work on the Indian Reservations where they made their homes. Their work was to commence by July 1, 1933. Enrollment was open to any male 18 years and over who was able to perform ordinary labor without injury to himself. Cash allowance was thirty dollars per month, with an additional allowance for food and quarters. No marital restrictions were placed upon enrollees, nor were they required to live in barrack-type camps. These specific provisions applied only to the Indians, and because of the

$$
\begin{aligned}
& 30 \text { Ibid., p. } 10 . \\
& { }^{31} \text { Ibid., p. } 16 .
\end{aligned}
$$


nature of the arrangements, the Army was not involved in their enrollment, conditioning or in the administration of their facilities. ${ }^{32}$

Provisions without restrictions were also made for the enrollment of young men who were residents of the Territories of Alaska and Hawaii, and the insular possessions of Puerto Rico and the Virgin Islands.

The inclusion of war veterans, Indians, territorials, and local experienced men expanded the scope of the Civilian Conservation Corps program. It extended a measure of relief to increments of the population in real need and at the same time resolved certain political problems of considerable consequence.

War veterans had twice marched on Washington, hoping to alleviate their situations in a distressed economy and labor market by early receipt of their "bonus" payments. Their efforts had met with failure and frustration, but the government could not afford to overlook their plight indefinitely. Employment in the Civilian Conservation Corps provided one means of paying a debt of gratitude and an opportunity to utilize the skills, experience and discipline acquired in previous government service.

By employing local experienced men, the potential for localized discontent and criticism was minimized, and another means of local relief was established. In addition, the LEMs would be a mechanism through which the inexperienced junior enrollees could acquire the neèded vocational training.

32 Ibid., p. 17. 
Indians had never had any capital to speak of, only natural resources which could not be converted into cash or supplies in a time of depression. By 1933, their annual income was at the vanishing point because of the drought and other conditions. By making provision for local employment in the CCC, without age or marital restrictions, the government provided an alternative to the Indians that would mitigate their circumstances, without removing them from their own environment or exposing them to additional prejudice and other adverse experience.

The amendment to the original legislation prohibiting exclusion from enrollment by reason of race, color or creed was an attempt to answer the unemployment problems of the blacks. In chronic poverty, the black population experienced a much higher rate of unemployment than did white citizens. Traditionally holding only the most menial jobs, they were the first to be laid off, so that white men could be gainfully employed in their places. Denied any civil recourse, they were in great need. But problems arose in recruiting young black men for the Civilian Conservation Corps, particularly in the South. Avoidance strategies were evolved, and when pressure was brought to bear on local agencies and on the State Directors, compliance was frequently reluctant. Token enrollment ultimately ensued, but not without resistance. 33

It was never a policy to create a nationwide system of integrated camps. Whenever possible, camps were strictly segregated, and integration was permitted only when black enrollment was too slight to form an

${ }^{33}$ Salmond, The Civilian Conservation Corps, pp. 88-91. 
al1-black company. Too, black companies were restricted to their home states and were not allowed the latitude of travel permitted to white enrollees. 34

The placement of all-black camps was conditional upon acceptance by local communities. CCC Director Fechner observed that "there is hardly a locality in this country that looks favorably, or even with indifference, on the location of a Negro CCC Camp in their vicinity."35

Recruitment and placement policies as they were developed contravened both the spirit and the letter of the CCC legislation. Blatant discrimination in the establishment of selection quotas was evident, but it resolved in some degree the problems of placement. What the established policies did not resolve was the blacks' need for some measure of relief in proportion to their population and economic privation: only approximately 200,000 blacks were enrolled in the CCC during the nine years of its existence. 36 In this limited sense, it was a positive achievement; at least some of its obligations toward unemployed black youths were fulfilled. Those who were able to enroll were given better clothing, shelter, and nutrition than they had had previously, and they received valuable academic and vocational training. By July, 1933, the Army had constructed District and Company camps in designated suitable locations throughout the National Forest

${ }^{34}$ Ibid., p. 91.

35 Fechner to Rep. J. G. Polk (Dem., 0.) October 20, 1934 in Director Correspondence as cited in Salmond, p. 92.

${ }^{36}$ Salmond, p. 101. 
System lands. Many of them were in the forests of Oregon and Washington, which comprised the Ninth Corps Area. Existing stocks of bedding and tentage were used. When the enrollees arrived, they assisted in the construction of temporary side camps and "spike camps" from which individual crews worked on the various assigned projects. It was not until the fall of 1933 that arrangements were made for semi-permanent housing for the enrollees at base campsites and for administrative and support structures for the camps. These were constructed, whenever possible, by contracting with civilian construction firms. 37

The Civilian Conservation Corps rapidly achieved credibility as a relief agency, and maintained popular public support throughout its existence, although few citizens realized the extent of the CCC's work. Numerous magazine and newspaper articles publicized the Civilian Conservation Corps, but few revealed the true scope of its operation. Reforestation and such soil conservation projects as the "shelter belts" of the dust bowl areas of the Great Plains were identified in the public mind as the primary CCC activities. Most American citizens were unaware that erosion control extended to bank sloping for stream and lake bank protection; to the construction of check dams, both temporary and permanent, to treatment of erosion gullies; to seeding and sodding to prevent further sheet erosion; to terracing and terrace outletting; or to the quarrying, crushing and hauling of limestone for liming soil; to the placement of water spreaders, and the construction of contour furrows and ridges. Much of this work was done on marginal

37 War Department, Civilian Conservation Corps Regulations, (Washington, D. C.: Government Printing Office, 1937). 
or sub-marginal farm land, but much erosion was controlled on grazing lands as well.

Nor was the public really conscious of the other work done on forest lands. Forest stand improvement was carried out by the removal of the culls, giving the trees remaining more light and moisture. The materials removed went into fuel wood, poles, fence posts and charcoal.

The CCC's built or maintained many thousands of miles of fire roads and truck trails, making more rapid fire suppression possible through greater access. These roads also opened new areas for the use of timber and other resources, and for public recreation and enjoyment.

CCC crews checked or controlled tree and plant diseases such as blister rust by grubbing out and destroying the: host species. Pine and bark beetles, spruce sawfly, and tussock moth infestations were also checked or controlled.

Such activities as fire prevention and suppression and control of tree and plant diseases and insect pests were of paramount importance, especially in areas such as the Pacific Northwest where the areal economy was and is largely dependent upon its timber resources.

Grass or forage is another important natural resource in the West, and the CCC worked to improve overgrazed range lands on the National Forests, public domain and Indian reservations by improving water developments, by reseeding or resodding denuded areas, by pasture and range terracing and by building stock drive ways and drift fences. Three million unemployed and often underprivileged young men enrolled in the Civilian Conservation Corps over the nine and one-third 
years of its operation. By July 15, 1933, there were more than three hundred thousand youths and veterans at work on conservation and improvement projects: by September, 1935, there were more than five hundred thousand " $\mathrm{C}$ ' $\mathrm{s}$ " in camps in every state and in the territories of Alaska and Hawaii, and in the insular possessions of Puerto Rico and the Virgin Islands. 38

The young men came from many backgrounds and circumstances, from both rural and urban areas. Many had never seen a National Forest, much less had any outdoor experience in a forest or mountain environment. Others came from rural southern areas, sons of tenant farmers and sharecroppers, who had existed in depressed conditions with inadequate nutrition for many years. Some from urban centers, lacking job or recreational opportunities, had drifted toward delinquency. Many had limited education, some to the point of illiteracy. Once enrolled, each boy had the opportunity to remedy these collective deficiencies.

\section{ACTIVITIES IN THE PACIFIC NORTHWEST}

Transported to the Pacific Northwest, the enrollees of the Civilian Conservation Corps worked in the forests that blanket the Cascades, the Coast Mountains, the Olympics, the Siskiyous, the Wallowas and the Blue Mountains. They received shelter, medical care, and quantities of good food. Those enrolling after 1935 could avail themselves of the educational program instituted to provide basic reading and writing skills and other academic course work as well as voca-

38 McEntee, Final Report, p. 42. 
tional training and work experience. They also had the opportunity to engage in recreational pursuits organized after working hours, and to associate companionably with others of both similar and different backgrounds. A tremendous esprit de corps was developed in this way. Enthusiasm for the job and pride in their new-found skills extended beyond the eight-hour work day. A CCC company assigned to the Growden Camp on the Colville National Forest spontaneously volunteered to improve their own surroundings. Applying the skills in stone masonry and concrete work they had learned, they built a decorative and functional water fountain of native shale with a reflecting pool. The catch basin of the fountain was fashioned from an inverted galvanized garbage can lid. Other crews and companies similarly created visual amenities for their own enjoyment by landscaping their camps. Some devised swimming "pools;" others built baseball fields.

Twenty-three camps were approved for the winter period 1933-34 on National Forests in the state of Oregon, of which eight were newly established. Because the enrollees could not profitably be employed on the Forests at higher elevations during the winter months, the practice was to remove the companies to the coastal and southern Forests and then return them to the inland areas for five or six months during the summer field season. This practice is borne out in the locations of the approved camps: five camps were located at lower elevations on the Willamette National Forest, four were on the Siuslaw, three on the 
Umpqua, four on the Rogue River, five on the Siskiyou, and two on the Mt. Hood, one at Zigzag, the other at Estacada. ${ }^{39}$

Testimony to the diffuse origins of the enrollees is found in records of the Wallowa (now Wallowa-Whitman) National Forest. The first company assigned to the Forest was mainly comprised of local boys, with a considerable number of enrollees from Union County and none from outside the state. Leaving on October 17, 1933, the company was reassigned to the Willamette National Forest for winter work. On April 30, 1934, Company 非1624, composed of boys from Illinois, arrived at Enterprise to commence work. Moving from Camp Yachats on May 2-3, 1935, Company $\left.\right|_{1963}$ was a unit formed from Oregon state ro11s, with almost seventy-five per cent from Portland. The enrollees of Company \#2110 which reported for work on May 2, 1936, were from Massachusetts. On May 1, 1937, CCC Company $\$$ \$ 4775 arrived at Enterprise from Mary's Creek on the Willamette National Forest. There were one hundred-sixty enrollees in the company, most of whom were from Minnesota, and of Scandinavian descent. 40

There was no CCC camp on the Wallowa National Forest in 1938, because of reductions in recruitment and camps. However, a detached crew of fifteen enrollees from the Squaw Creek CCC Camp on the Umatilla Indian Reservation worked on the buildings at the Wallowa Ranger Station for a period of time. ${ }^{41}$

39Washington, D. C., National Archives and Records Service, General Services Administration, "CCC Camps Approved For Winter Period 1933-1934, State of Oregon"

40"The CCC Program 1933 to 1941, Wallowa National Forest," (Typescript, no date) pp. 197-207.

41 Ibid., p. 208. 
On May 2, 1939, the one hundred-thirty-five enrollees of Company \#282 from New York and New Jersey arrived to complete several projects under way, including the Wallowa Ranger Station. Company $\$ 282$ returned to Enterprise in 1ate June, 1940 from winter camp near Grant's Pass on the Umpqua National Forest with an enrolled strength of only sixty men. The disbanded remnant was incorporated with Company 非640 which had been recruited in Alabama and Georgia, arriving at Enterprise on July $27,1940.42$

Company 非440 was sent to Camp Rand, Galice, Oregon on the Siskiyou National Forest for winter camp, but returned to Enterprise in May, 1941. With more job opportunities becoming available in a recovering economy, the enrolled strength of the company dwindled from two hundredone to eighty-seven by August. The camp was disbanded at this point and the remaining enrollees dispersed to other companies. ${ }^{43}$

This pattern of nationwide as well as local recruitment, transportation, encampment, work and transfer was typical, repeated with every CCC Company on every National Forest.

Juniors were paid $\$ 30.00$ a month, of which $\$ 22.00$ was deducted for allotment to the enrollee's family or designated beneficiary. This provided an added measure of financial relief to families dependent on the state or county relief rolls, and in many cases, it was the sole source of income. 44

$$
\begin{aligned}
& { }^{42} \text { Ibid., p. } 208-209 . \\
& { }^{43} \text { Ibid., p. } 209-210 . \\
& 44 \text { McEntee, Final Report, p. } 20 .
\end{aligned}
$$


Few enrollees had any previous experience in carpentry, building or road construction, or in any of the skills necessary to conservation work, but supervised by foremen of wide experience and taught by the Local Experienced Men (LEMs), the enrollees learned. 45 The quality of their work bespeaks the effectiveness of this arrangement. The project supervisors and crew foremen were Forest Service employees. The Local Experienced Men were craftsmen in the building and stone masonry trades who were otherwise unemployed or in need of work, and who lived in the project locality. The employment of Local Experienced Men served two purposes: it supplied local economic relief, and it provided a necessary source of skill and experience to accomplish the scope of improvement work planned.

The immediate benefits of the Civilian Conservation Corps and other Depression-era programs and work projects to the Pacific Northwest were employment for individual local residents, both young men and experienced craftsmen, financial relief for families through this opportunity for useful work, and economic stimulae for communities through purchase of supplies and materials. Local businesses were also assisted by the trade of the CCC enrollees themselves.

Another collateral socio-economic advantage which came from the CCC program--particularly in its early days--was found in the impetus it produced in many industries due to its necessarily large expenditures. The lumber industry was among those floundering deepest in the deptins of the depression and was one which received very substantial 
assistance from the hundreds of millions of board feet of lumber required by the CCC to build its camps and carry on its work projects, most specifically the construction of Forest Service administrative and protective structures. The quantity of dimension lumber required to build a.single ranger station compound was immense, and the quality of that lumber may be, in part, responsible for the soundness of the surviving structures.

The long-term benefits to the region were the results of the reforestation projects, the forest stand improvement, the work of fire prevention and suppression, the control of tree diseases and insect pests, and the range land improvements on the National Forest System lands. Because timber is the primary resource in the areal economy and because water and forage are essential resources to the stock raising industries, the conservation activities of the CCC in relation to these resources assured a continuing growth of private industry based on these public resources, and support of the areal economy in terms of continuing supply and available employment. 


\section{CHAPTER III}

\section{FOREST IMPROVEMENTS}

A salient factor in the CCC program was that the work done was not "made work" but consisted of tasks that really needed doing. The need for forest improvements was great, as the work of the Forest Service had expanded from its earliest responsibilities.

Administration of the natural resources was implicit in the Organic Act of 1905. Although the term "multiple use" was not made explicit until 1960, wise use of many resources, including timber, forage, water and wildlife was a recognized operating principle. Recreation was likewise considered a legitimate use. 46 Forest improvements were not specifically enumerated as project areas in the Emergency Conservation Work Act, but were held to be within the defined sphere of "works which are not available as projects for public works." They were jobs done in accordance with good engineering and good commercial practice with proper supervision, tools, machinery, materials and supplies complementing the human labor required. The work, while labor intensive, was not accomplished by large groups of men equipped with picks and shovels when it was more appropriate to complete a task with relatively few men plus the right machines. 47

46 The Organic Act of 1897, (30 STAT. 34, as amended; 16 U.S.C. 473-478, 479-551).

47 McEntee, Final Report, p. 64. 
It is the forest improvements constructed by the Civilian Conservation Corps that are the most recognizable evidence of their service; districts, sites, buildings, structures, and objects that possess integrity of location, design, materials, workmanship, feeling and association, and that are associated with events that have made a significant contribution to the broad patterns of our history. 48

In accordance with responsibilities defined in Executive Order 11593 (President Richard M. Nixon, May 13, 1971) the Pacific Northwest Region of the U. S. Forest Service has undertaken to locate, identify, evaluate, protect and enhance the forest improvements constructed or improved by the Civilian Conservation Corps as historical cultural resources. Individually and collectively, the administrative, protective and recreational sites and structures reflect the comprehensive planning typical of the era, and represent a distinctive style of architecture. Durability of construction, attention to detail and quality . of workmanship are exemplified in the improvements of the Civilian Conservation Corps. But beyond this, an ethic of non-intrusiveness is embodied in the sites and structures. Whether rugged as typified by recreational facilities, or refined as found in the administrative structures and their support buildings, the improvements harmonize with their environment, becoming almost a part of it.

Prior to the Depression, the Forest Service building program was limited. Buildings were erected when and where they were needed, with little advance planning and minimal consideration for future needs or

4836 CFR 60.6. 
expansion of facilities. When confronted with the task of developing work projects and operating schedules for the proposed Civilian Conservation Corps, a concerted effort was made to include anticipated future needs as well as immediately required facilities in the planning process. Comprehensive planning with careful provision for possible expansion became a standard operating procedure and the great majority of administrative sites, ranger stations and service compounds reflect this. Thoughtful planning resulted in a properly balanced arrangement of buildings and grounds, and involved economical. development, harmony with surroundings and conformation with existing physiographic conditions.

Because the National Forests were not parks, exclusively recreational in character, but were intended to serve highly utilitarian purposes, it rapidly became apparent that it was necessary to provide buildings adequately to accommodate and house the personnel and equipment required to conduct properly the varied phases of Forest Service work. In accordance with the decentralized organization of the U. S. Forest Service, each component became responsible for specific elements of planning and implementation.

\section{ADMINISTRATIVE SITES AND STRUCTURES}

\section{Planning and Design}

The Washington office established standards and guidelines for construction and materials. In the Improvement Handbook, prepared by the Division of Engineering, preliminary planning for building developments was discussed, including material specifications. Construction 
schedules and work plans were outlined, so that Forest personnel in the field responsible for directing and supervising the projects would have a procedural model. Excavation, footings and foundations, wood preservation techniques, light building construction, heavy timber construction, scaffolds and towers, log construction, concrete, masonry and brick construction, roofing materials, interior finish, heating, plumbing and electrical service were defined, described and illustrated. No facet of preparation, construction or finish was omitted; preferred techniques were indicated as were preferred materials. 49

The standards promulgated by the Washington office and embodied in the Improvements Handbook were the basis of all construction in all Regions, being general specifications and instructions for any building procedure. Further, Forest Service policy relative to the use of wood was made explicit:

The Forest Service in its own construction work should use wood to the fullest practicable degree. The use of other materials in lieu of wood should be considered and authorized only when their suitability and durability clearly exceed that of wood, or where the use of such substitute materials is made necessary by the general type or design of the structure, or where the first cost plus maintenance cost of wood would so greatly exceed the first cost plus maintenance of other materials that it cannot be justified on any demonstrational or economical basis or where the use of lumber is at variance with City, County, and State building codes. 50

Each Regional Office was responsible for preparation of site plans, for design of individual structures, and for landscape plans.

${ }^{49}$ U. S. Department of Agriculture, Forest Service, Improvement Handbook, Division of Engineering (Washington, D. C.: Government Printing office, 1937), pp. i-xịv.

${ }^{50}$ Ibid., p. 71 . 
Each Forest was responsible for the selection of sites appropriate for proposed development plans; selection criteria included the convenience to utilities, transportation, schools, and development costs in relation to topography, soil, cover and exposure.

The predominating style of architecture found in Forest Service structures built during the Depression was "rustic." This uniquely American architectural style evolved slowly, a natural outgrowth of (late) nineteenth century romanticism about nature and the western frontier. As accessories of nature, these structures employed the use of native materials to blend with the environment and the use of early pioneer and regional building techniques; architecture was closely integrated with landscape.

The earliest articulation of the relationship between architecture and its environment is found in landscape architect Andrew Jackson Downing's book, Cottage Residences; published in 1842. Later, Frederick Law 0lmstead, Sr., a friend and student of Downing, significantly reinforced the connection between architecture and landscape architecture in his work. 51

In the San Francisco Bay area of California, a group of five architects including Bernard Maybeck, sought innovative ways to use natural materials. Ornamentation became unnecessary if a textura1 richness could be achieved by juxtaposing materials and shapes. 52

${ }^{51}$ William C. Tweed, Laura E. Soulliere, and Henry G. Law, National Park Service Rustic Architecture: 1916-1942, (San Francisco: National Park Service, Western Regional Office, Division of Cultural Resource Management, 1977), p. 3.

52 Ibid., p. 5 . 
Similar architectural theory was developed in the National Park Service as they attempted to develop non-intrusive architecture through sensitive use of native materials and architectural forms proportional to the surrounding environment. Park Service architects also experimented with new construction methods that visually imitated pioneer building techniques. By the late 1920's, eloquence in the style had been achieved, and the major public buildings erected in the National Parks during the Depression reflect that achievement. 53

Although the Forest Service had had no particular opportunity or reason to develop a similar building program prior to the Depression, the prevailing Park Service ethic of non-intrusive architecture was found to be appropriate and adopted. Each Forest Service Regional Office undertook to design structures appropriate to climate characteristics, vegetation and forest cover, utilizing the predominant native building materials. Some Regions were able to take advantage of their traditional or native architecture while others found it necessary to develop original designs based only in part on regional prototypes. There emerged from each Region an architectural style that was distinctive to both that Region: and to that period of time.

\section{Site Locations}

Region Six, then the North Pacific Region, now the Pacific Northẅest Region, included nineteen National Forests in Oregon and Washington, with widely varying topographies, disparate climatic characterist-

$$
53 \text { Ibid., p. } 47
$$


ics, diverse forest cover, and no identifiable native or traditional architectural style.

The problems of design for such diversity were complex, but were made manageable by the process of site selection and description. Each Forest in the Region had identified strategic areas for administrative and protective sites. Specific sites within the strategic areas were then selected based on practical criteria. Low ground lacking natural drainage, property located within an area subject to periodic inundation, mud flows or other erosive conditions, boggy ground, property having inadequate opportunities for sewage disposal or insufficient water supply, property having immediate subsurface rock, properties. in cold regions having northern exposures, properties inadequate for future expansion, properties which would require excessive cut and fill, terracing and grading were to be avoided if at all possible. 54

\section{Site Development Plans}

Having determined the location of the administrative or protective site, the Forest then submitted to the Regional office a development plan which included a landscape plan showing designs for the entrance, gate, fences, or walls as needed, based on a minimum planning period of fifteen years, a topographic map and a utilities plan showing the location of the main features such as wells, reservoir or water tank, septic tank and distribution field. The Forest also indicated

54 U. S. Department of Agriculture, Forest Service, Acceptable P1ans Forest Service Administrative Buildings, Division of Engineering, (Washington, D. C.: Government Printing Office, 1938), pp. A-4, A-5.' 
which "Standard Building Plans" were appropriate to the needs of the site, stating if the hand of the plan was to be reversed, and/or submitted pencil sketches of recommended structures when standard plans were not appropriate or did not exist. 55

The "Standard Building Plans" were floor and elevation plans of structures of general and uniform utility, (e.g. two, four or sixhorse stable, four-room office, six-room dwelling, or two-room cabin), which might have specific application to a particular topography or environment.

To avoid previous conditions of building congestion, promiscuous location or the erection of occasional structures at interrupted intervals which led to inefficient operation or lack of complete supervision and control, the Regional office attempted to plan comprehensively for serviceability and utility. With provision for possible future expansion, each compound was designed to take greatest advantage of available public utilities, water supply, sewage disposal, electric, telephone and radio services. Accessibility as represented by ingress and egress from the highway or other roads of approach was considered as fully as vehicular circulation within the property itself. Paramount was a design which allowed complete control, surveillance and supervision by direct observation to insure full knowledge of personnel performance and efficient operation at all times as well as separation of public, semi-public, and service portions of the compound to avoid

$55 \mathrm{U}$. S. Department of Agriculture, Forest Service, Technical Handbook Administrative Site Plans, North Pacific Region (Revised 6/20/52), 
interference or interruption of operations. Equally important was the functional or utilitarian arrangement of buildings for purposes of maximum efficiency and service. Finally, landscaping studies, including the general planting scheme, lawns, walks, walls and fences, were integrated into the comprehensive plan. ${ }^{56}$

When the comprehensive plan was established, the planning of the respective buildings was undertaken to fulfill their particular requirements. The most effective plan (rectangular, "T", "L", "U", "H") for a particular function had been determined, and was evidenced in the "Standard Plans." Such fundamental design principles as ample daylight, cross-ventilation and direct circulation were incorporated in those determinations. 57

Provided by the Forest with pertinent data regarding site orientation and topography, Regional office architects and engineers, among them Linn A. Forrest, E. U. Blanchfield, H. L. Gifford and J. K. Pollock, were able to design individual buildings which were appropriate, attractive and practical.

Design of elevations was to some extent limited by the use of a restricted number of materials native to the area for exterior construction. Climatic conditions, environment and economy also imposed certain limitations. The sizes, shapes and finished surfaces of the various forms of wood used in the exterior walls of frame buildings

56 Forest Service, Acceptable Building Plans, (1938), pp. A-6-A-9. 57 Ibid., p. A-9. 
were the attributes which largely determined their design. Only mass, line, proportion, fenestration and color remained unrestricted.

Although each building in a compound was planned for a specific function, a uniformity of style was achieved through similarity of character and appearance. A basic roof shape was repeated throughout a compound while monotony was avoided by variation in size, position or number of similar shapes. Regularity of exterior wall material and roof material produced a harmonious texture, an attractive homogeneity. Decoration was, in fact, quite subtle: frequently it consisted only of a particular end treatment of the vertical boards on the gable ends, with or without battens, or in the massing of multilight sash windows. Almost without exception, structures in Region Six exhibited vestibuled or covered entrances, front and rear, that were entirely consistent with the design of the structure or even part of the fabric.

The office was the center of prominence in the building group and was located so that it was readily accessible to the public. It also served as the control point for all business traffic entering and leaving the ranger station. 58

At Supervisor's Warehouse sites the office was usually placed within one of the service buildings, its placement depending upon the type of adjacent service buildings and the relative need for accessi-

58 Forest Service, Administrative Site Plans, North Pacific Region, p. 8. 
bility between them. In most cases, the building housing the office was centrally located within the court and close to the entrance. 59

A public parking area was planned adjacent to the office with official car parking areas located close to the office for convenience without interference with public traffic. 60

A flagpole near the office identified the importance of the building; it was usually off-set rather than directly in front to avoid a divisive appearance.

The service court itself was located in an area of the administrative site that offered the greatest potential for expansion. The general form of the court was determined by the topography, property lines; existing cover and the alignment of the main road. Ideally it was screened from public view to minimize scenic detraction. 61

Buildings within the court were placed for a logical handling of activities and maximum accomplishments, in short, for greatest efficiency. Gas and oil buildings were placed a minimum of fifty feet from other structures, with maximum accessibility. Warehouses, shops and equipment storage buildings were located at least twenty feet apart. Forty or fifty feet of separation was preferable for both appearance and fire protection. 62

The general warehouse and the fire warehouse were of primary importance in terms of frequency of use and actual function. Both had

$$
\begin{aligned}
& 60^{\text {Ibid., p. } 8 .} \\
& 61_{\text {Ibid., p. } 8 .} \\
& 62_{\text {Ibid., p. } 8 .}
\end{aligned}
$$


to be equally accessible with adequate space to permit the approach of trucks for loading without excessive maneuvering. The machine shop was next in importance to the warehouse in volume of traffic and so was placed to allow for a driving space of fifty or sixty feet in width about the building. The blacksmith shop was located in convenient proximity to the machine shop with sufficient court width for movement of machinery. All other unit service buildings were planned to bear a direct relationship with the buildings to be served. 63

Because machine and equipment storage buildings were used less frequently than the warehouses or gas and oil buildings, they could be located toward the rear of the service court, albeit adequate space for maneuvering equipment into the building without difficulty had to be allowed. 64

Barns and corrals were ordinarily placed to the rear of the quadrangle and frequently outside it, although a barn designed to accommodate no more than eight horses could be planned as an integral part of the service group. In any event, it had to have sufficient space for a corral and have ready access to a pasture. Larger barns were located in an area separate from the service court. Whereas the size of such a structure and its design might not conform to the other service buildings with complete harmony, similarity in character to the other structures was encouraged. 65

$$
\begin{aligned}
& 63 \text { Ibid., p. } 9 . \\
& { }^{64} \text { Ibid., p. } 9 . \\
& 65 \text { Ibid., p. } 9 .
\end{aligned}
$$


It was considered important that the residential area of a ranger station be given privacy and freedom from the noises and sights of the working activities of the compound. Although not always possible, an entrance driveway separate from the main service entrance was desirable. $6 \dot{6}$

Residences were grouped to form a pleasing unit, with due consideration given to ground development and maintenance. The Ranger's residence had the greatest degree of privacy, while the Protective Assistant's residence was ordinarily located adjacent to the office. Housing facilities for the crew were usually separate from the residence group, and in most cases, in proximity to the service court. A caretaker residence was provided at Supervisor's Warehouse sites, and placed so that a clear view of the entire compound and the approach road was possible, for security and for service purposes. 67

\section{Landscape Planning}

Landscaping and planting at administrative sites followed the completion of building construction as closely as possible. Economy as well as enhancement was important, and planning considered both the plants, shrubs and trees growing on the site and plants native to the vicinity. Planting west and east of the Cascade Mountains presented separate problems. Material selected for use on westside sites had to be able to withstand excessive moisture, while species selected for

$$
\begin{aligned}
& { }^{66} \text { Ibid., p. } 10 . \\
& 67 \text { Ibid., p. } 10 .
\end{aligned}
$$


planting on east side sites had to be tolerant of extremes of heat, cold and drought. On the western slopes of the Cascades, planting was primarily a problem of re-establishing trees and shrubs around the buildings and grounds in an effort to blend new construction with the existing landscape. Planting costs could be reduced and immediate planting effect insured if care was taken to preserve as much of the existing growth as possible. 68

Eastside stations, particularly those out of the timber, presented a greater planting challenge. Many indigenous shrub species did not provide attractive domestic plantings, and considerable care had to be taken to establish exotic (non-native) materials on the sites. The first objective was to plant vigorous growing trees to provide shade and to frame the buildings. In many cases, exotic trees and shrubs had been introduced in the vicinity of the stations, and being suitable, were used in place of native plant material. Black locust, Chinese elm, Lombardy and Carolina poplar and Russian mulberry of ten proved satisfactory for dry eastside 1ocations. ${ }^{69}$

The intensity of planting at sites away from the main routes of public travel was less than the planting at more important Ranger and Guard Stations. Warehouse sites as a rule were considered as adequately planted by the use of trees in groups and masses and the use of. ground cover. ${ }^{70}$

$$
\begin{aligned}
& { }^{68} \text { Ibid., p. } 15 . \\
& { }^{69} \text { Ibid., p. } 15 . \\
& 7^{70} \text { Ibid., p. } 15 .
\end{aligned}
$$


Good lawns were termed a prerequisite for a well-developed site, whether office or residence. This did not necessarily mean broad, expansive lawns, but we11-kept lawns of a size easily maintained at minimal cost. A limit of approximately 3,000 square feet was designated, except by special approval of the Regional Forester. 71

\section{ADMINISTRATIVE RUSTIC ARCHITECTURE}

Such detailed planning produced practical, logical, efficient and economical results. The ranger stations, guard stations and warehouse compounds erected from these plans were aesthetically pleasing as well as substantial buildings compatible with their surroundings, and cohesive in their unity of style, materials, proportion, color and texture. Plans on paper were translated into built communities, slightly separate from their localities, just as the Forest Service itself was a community within the whole of society.

No changes in approved plans could be made without the specific approval of the Regional Forester. Changes in building plans such as enlarging one unit or changing its position, adding a room or a window, changing the slopes of the roof, or changes in either plan or elevation which might violate the aesthetic or utility value of the design were clearly discouraged, and were to be made only by the architectural section of the Division of Engineering in the Regional Office. 72

${ }^{71}$ Ibid., p. 33 .

72 Forest Service, Acceptable Building Plans, R-6 Insert Sheet, p. A-20. 
Yet, throughout the Region, many deviations from these instructions occurred. In comparing extant working plans and specifications with a completed structure, modifications and innovations may be noted for which there is no documented approval. These changes were made by the Civilian Conservation Corps construction crews, most probably for very practical reasons, and remain as testimony to their ingenuity and resourcefulness.

The administrative and protective structures, residences and support buildings of the Depression era are without superfluous ornamentation. Richness of texture, juxtaposition of shapes and materials made them aesthetically pleasing. However, many of these structures exhibit an additional discreet decorative feature, the hallmark of Civilian Conservation Corps construction. The "pine tree" logo of the U. S. Forest Service (and the Civilian Conservation Corps) is found in many shapes, sizes and forms on the buildings of that period.

Because the pine tree symbol appears on structures in all Regions of the Forest Service, it seems certain that a directive suggesting its inclusion in design was issued from the Washington office. The phenomenon is too widespread to be a regional innovation, and is limited to Forest Service structures, voiding the notion that the impetus for it came from the CCC Director. Structures built by the CCC for the National Park Service and for other agencies within the Department of Interior bear no equivalent symbol or insignia. Specifications for design, size, and placement of pine trees do appear on the working plans for the Forest Service structures drawn in the Regional office, but far more frequently than not, numbers and placement exceed those 


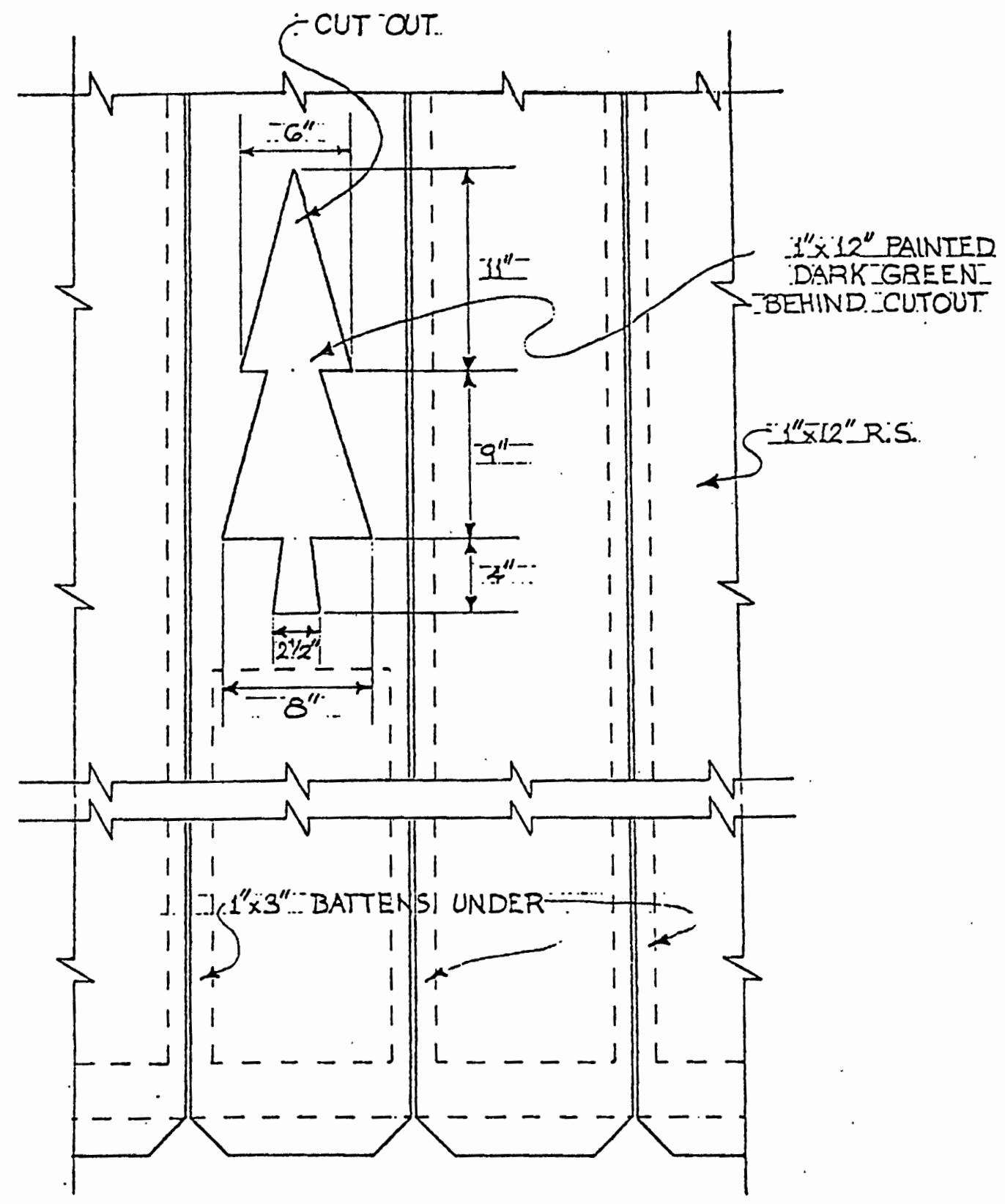

\section{CUT OUT IN \\ GABLE ENDS}

SCALE:11/2".:-1'-O" 
specifications, and even more frequently the trees bear little resemblance to the design. In addition, there is tremendous variety of interpretation, not only from compound to compound but also from building to building. In this one feature, the CCC crews found a means to express themselves, to put their own impress on their constructions.

Pine trees were cut from single boards, or formed by silhouettes joined by two boards; pine trees were cut from one board and applied to another. Pine trees appeared singly and in combinations, in linear and pyramidal patterns, in graduated and in equal sizes, on gable ends, on porch pediments and on dormers, on shutters, and on stair railings, on mail boxes. Nor were they limited to the medium of wood. Pine trees were cut from stone, on fireplaces and on warehouse walls; pine trees were formed in wrought iron and forged as latch plates.

Some structures had none, others only one; one warehouse had thirteen. Number, placement and arrangement appear to have been, in many cases, a matter of taste. The nature of exterior wall material was also a decisive factor; vertical boards lent themselves to this motif more so than did horizontal shiplap or clapboarding. But wherever it was possible, pine trees appeared: from simple triangular designs, to strange, squat representations, to angular combinations, to graceful and well-defined trees, with and without bases.

\section{Region Six Architectural Style}

The administrative structures of Region Six are not highly stylized $\mathrm{log}$ and stone buildings reminiscent of pioneer technologies, but are still distinctively rustic. More refined, they are at the same 
time decorative and functional. Typically, they have nailed-wood frames, with poured concrete foundations, of ten veneered with native stone. Gable roofs, with pitch appropriate to climatic conditions, were the primary design, with variations such as hipped gables or gabled hips common; hipped roofs were less frequently utilized. Porches, hoods and dormers repeated the roof shape and trim. Roof materials were wood shingles or split shakes. Characteristically, the roof trim, the eaves and verges, project, with rafters and even purlins exposed.

Chimeys, both interior and exterior, were common; many residences had fireplaces and many more were initially heated with wood or coal. Most chimneys were at least veneered with the stone native to the locality, although brick was used in areas where the indigenous stone was unsuitable or where brick was felt to be the more appropriate medium. Frequently, the chimney masonry repeated the material and texture of the porches, steps, foundation veneer and landscaping details. The exterior wall materials were primarily wood, and often two or more textures were combined. Horizontal clapboard, vertical board and batten, wall shakes, wood shingles, and shiplap (with and without end trim) were commonly used. Stone was used as a supplementary medium, although some structures exhibit whole facades of native rock. In one surviving example, stone was the primary exterior material, and wood was the secondary medium.

The heavy squared timbers often used as porch supports were high1y functional, but achieved a decorative purpose as well when arranged 
in pairs or in combinations of three. The brackets which served as structural reinforcement were also formed in a visually pleasing manner. Windows were perhaps the most distinguishing feature of the Depression-era structures. Single and double-hung sash windows with multiple lights served the utilitarian purposes of lighting and ventilating the interior of a building: singly and in combinations with mullions, the window treatments became an element of subtle ornamentation. Extensive massings of window-divisions in proportion to their size were characteristic of the larger service buildings, particularly machine shops and some warehouses, with identical treatments, or elements thereof, repeated on all elevations. Where the plan of each elevation of a building differed substantially, the reiteration of window treatment gave the structure a design unity otherwise 1acking. Nine and twelve light divisions in combinations of six or eight with mullions were frequently used; the same treatment was found in variations throughout the building group of a service court. Isolated individual structures might have single main facades of mullion windows with divisions of ten, fifteen and twenty lights.

Dwellings, particularly ranger's residences, used windows as explicit decoration. Decorated window surrounds, as well as visually attractive arrangements of window divisions were frequent. Smaller in scale, dwellings most commonly utilized double-hung sash windows, either six-over-six or eight-over-eight, singly or in combinations of two or three with mullions, with six or eight light single sash windows in secondary locations. Side lights and transom lights were infrequent- 
ly used, but occasionally found in mullion windows, rather than as entry features.

Shutters, most often of a purely decorative kind, were utilized on ranger station offices and on dwellings. Functional shutters were placed on guard station buildings and other isolated protective structures that were occupied only seasonally, as a protective measure against accumulations of snow or other weather conditions and against vandalism.

Before any administrative, recreational or special use structures were constructed, the colors to be used for the exterior finishing were to be approved by the Regional office. This approval was ordinarily covered in the preliminary sketch approval sheets submitted to the Forest Supervisor prior to the preparation of plans, which specified roof and wall colors. ${ }^{73}$

Colors of stains to be used for exterior finishes included: A-Light gray, B-Brown, C-Weather gray and white. Generally, the BBrown was to be used only on buildings within the ponderosa pine timbered areas, where the color would blend with that of the ponderosa pine bark. White could be used in open country or in settled communities. At other locations, the A or C stains or a combination of both were to be used, except for lookout cabs and ground houses which, without exception, were to be painted silver gray. The Region Six Insert Sheets (Revised 7/23/41) to the Acceptable Building Plans Handbook

${ }^{73}$ Ibid., R-6 Insert Sheet, p. A-20. 
directed that standard stains "Should be obtained through Central Purchase in order to secure better prices through quantity purchases." 74 Roofs were not to be painted. Where the body color of a structure was standard A, the standard C color stain was to be used on the roof. Where standard B-Brown was used on the body, standard A or C color stain was to be applied to the roof. Previously, green or brown stain had been used on roofs; this general policy was discontinued during the construction boom of the Depression era, and those older structures having incompatible roof stains were left to weather to the point where a compatible $C$ stain would cover by applying two coats. ${ }^{75}$ Interior finish was likewise specified. Where wall materials were chosen for grain or natural wood appearance, such as knotty pine, the woodwork was to be coated with spar varnish. Alternately, the woodwork could be stained appropriately and varnished, or the standard antique stain could be applied and then waxed. When using the antique stain and wax finish, a sealer was to be applied first to assure an even coat of stain. Care was to be taken in staining to prevent the walls from becoming too dark. 76

Wall surfaces not selected for grain, such as interior plywood or narrow interior shiplap, were to be painted. Paint colors found most suitable were shades of ivory, tan, cream-gray, cream, buff, canary yellow, and pale green, as given in the Sherwin-Williams color chart. Too vivid or otherwise undesirable colors such as orchid, bright blues,

$$
\begin{aligned}
& 74 \text { Ibid., p. A-206. } \\
& 75_{\text {Ibid., p. } A-20^{6}} . \\
& 76 \text { Ibid., p. A-207. }
\end{aligned}
$$


or pinks were to be avoided. ${ }^{77}$

Ceiling colors, as a general rule, were to be the same color as the walls, or of harmonizing shades. Sharp contrasts on all interior work were to be avoided; where two shades were used, the ceiling was to be the lighter color. ${ }^{78}$

Fir floors could either be left natural and varnished, or stained a desired color and then varnished, with care taken to finish floors "as light as practicable."79 0ak floors were to be sanded, paste filled, two coats of pure shellac or flat floor varnish applied, and then waxed.

Subsequent to this period, general policy on building coloration again changed, and while uniformity of color is still standard, the range of acceptable exterior paint and stain colors has expanded to include rust, gold, tan, several subdued shades of green, discreet shades of yellow and charcoal. Attractive combinations of colors, with complementary or contrasting trim has enhanced the appearance of the already distinctive rustic architecture of many ranger stations, service compounds and work centers, without detracting from their historic integrity.

\section{RECREATION SITES AND STRUCTURES}

\section{Planning and Design}

Recreation sites and structures were a separate classification of

77 Ibid., p. $\mathrm{A}-20^{7}$.

${ }^{78}$ Ibid., p. A-207.

${ }^{79}$ Ibid., p. A-207. 
forest improvements. These were intended for public use and enjoyment, but also served to concentrate recreational use of the forests in protected and supervised areas, primarily to minimize fire risk.

Careful selection of site location was emphasized. Preferable sites for developed campgrounds provided scenic views, pleasant and beautiful surrounds, an ample water supply, effective drainage, accessibility to automobile traffic, and if possible location between any natural fire guards. In essence, site selection was based upon safety first and convenience, with proximity of other recreational opportunities considered. 80

Improvement of a campground site required detailed planning which included provisions for a water system, adequate parking and landscape development. Special buildings such as shelters, flush toilets facilities, children's playgrounds or other unusual improvements found necessary for inclusion required the approval of the Regional office. 81 After a definite plan for the improvement of a campground site was made, removal or reduction of the fire risk was the first step taken. This entailed removal of inflammable debris, litter and brush. Care was taken to insure adequate natural screens for toilets, garbage pits, and incinerators. It was also desirable to leave a screen of shrubbery between individual camp sites, because seclusion and privacy were held to be essential. Sufficient trees for shade and to maintain

80 . S. Department of Agriculture, Forest Service, Recreation Handbook, Region Six, (Revised 4/10/33), pp. 127-128.

${ }^{81}$ Ibid., p. 127. 
the natural beauty of the area were 1eft. It was recommended that trees and brush should be left in groups rather than placed as individuals. ${ }^{82}$

The Recreation Handbook for Region Six as revised 5/23/33, stated:

The Forest Camp should not take on the appearance of a museum or arboretum. Odd and contorted trees may be left, but we find that the average tourist wishes to see straight, healthy and vigorously growing trees and shrubs. 83

Forest camp roads were primarily a means of ingress and egress, but the locating of these roads in relation to scenic vistas and the beauties of the natural environment was encouraged.

Convenient placement of toilets, garbage pits, and incinerators was important. Built improvements were to be stained in natural or neutral colors to render them less conspicuous. Silver gray or french gray shingle stain were preferred as they conferred a "pleasant weathered appearance," and "blended with nature better" than brown or green stains. ${ }^{84}$ Few Depression-era pit toilets remain because environ- . mental and sanitation standards now preclude their use, but a number of flush-toilet facilities survive and remain functional. The toilet buildings at Toll Gate and Camp Creek Campgrounds adjacent to U. S. Highway 26 on the Mt. Hood National Forest reflect the application of recommended procedure: of pole construction and split shake exterior, they are made inconspicuous by screens of natural vegetation and by use of a neutral colored stain.

82 Ibid., p. 127.
83 Ibid., p. 128. 
Water developments were a primary consideration in some campground sites. Where springs were to be used as the supply, the source was to be walled up, either with rock or cement, and covered. Piped water systems required that several hydrants be located conveniently. "Hydrants should stand at least 36 inches from the ground and should be encased in rock or other native material to insure strength and beauty. " 85

To minimize fire hazard, camp stoves and fireplaces were provided as conveniences for cooking, warming, and lighting in campgrounds and picnic areas. Acknowledging that any man-made feature was an artificial note and an intrusion, efforts were made to design stoves and fireplaces that were attractive and appropriate, had-maximum utility and required minimum maintenance. No single stove type met all these requirements in every location: the natural topography of an area largely determined appropriateness. Massive high-chimney stoves were deemed appropriate only in large timber areas where there was adequate opportunity to screen the facilities. Similar stoves in an open forest area would produce an "unfortunate effect on the general landscape composition." 86

To retain scale and proportion, a height ranging from fifteen to twenty-four inches was prescribed for cooking surfaces; the walls of the stove were not to exceed this. Native stone was the preferred material, but the type of stone and the ease with which the stone

$$
{ }^{85} \text { Ibid., p. } 129 .
$$

${ }^{86}$ U.S.D.A., Forest Service, Campstoves And Fireplaces, by A. D. Taylor, (Washington,D.C.: Government Printing Office, 1937), pp.1-8. 
could be cut to the desired shape for the desired texture of masonry had to be considered in design. 87

Location of the stove or fireplace was extremely important in camp site planning. Stoves had to be easily accessible to tables, but could be no closer than ten feet to trees. There had to be sufficient working space around the stove for convenience and provision for fire wood storage. Finally, the direction of the normal prevailing winds was to be considered so that smoke, casual sparks or heat would not be blown into the tent or across the table. 88

The most frequently built stove design in the Forests of Region Six was the convertible camp stove, the texture of the masonry varying with the type of native stone available. Rectangular, with a chimney built into one end as part of the fabric, these stoves eliminated undue fire hazard, and provided for cooking and for warming fire use. Camp stoves exemplifying this design, although showing considerable textural variety, survive at Salmon Meadows Campground on the Okanogan National Forest and at the Union Creek Campground on the Rogue River National Forest. Within individual campgrounds, textural diversity is evident: some stoves are constructed of boulders, rounded, uncut and assembled in a very informal manner while others exhibit very carefully cut and fitted stone, more formal in appearance. Variations of the basic design that included a triangular warming fireplace abutting the cooking stove chimney are found in campgrounds throughout the Region. Surviving examples of this variation are found, in good condition, in

$$
\begin{aligned}
& { }^{87} \text { Ibid., p. } 9 . \\
& 88 \text { Ibid., pp. 9-10. }
\end{aligned}
$$


the To11 Gate and Camp Creek Campgrounds on the Zigzag Ranger District of the Mt. Hood National Forest.

The camp stoves at the McKee Bridge Campground along the Applegate River on the Rogue River National Forest represent a wide variety of designs and textures, ranging from convertible camp stoves, of both rounded boulder and cut and fitted textures--to crude open fireplaces of rock piled in a horseshoe shape. Elsewhere in the same campground there is a small campfire circle, defined by a circular construction of coursed stone, and having a metal pipe cooking standard with two projecting pot hooks. A community bonfire ring, defined by flat stones, and surrounded by $\log$ benches is located in the group picnic area.

\section{RECREATIONAL RUSTIC ARCHITECTURE}

While many of the campgrounds and picnic areas developed by the Civilian Conservation Corps represented entirely new construction, others had been informal occupancy sites for many years, and were merely enlarged and improved with more formal facilities added. In the instance of these developed occupancy sites, the term "rustic architecture" must apply to all increments of development, including the built structures, furnishings, interior and exterior, and landscaping features, as each was an integral part of the whole.

As previously noted, campgrounds were as carefully planned as administrative sites, and details of planning and design extended far beyond the bare necessities of facility. This was particularly true of the furnished features, and it was among these that the ingenuity of the Civilian Conservation Corps found its greatest expression. Camp 
fixtures such as tables and benches, and fireplaces and stoves, were constructed from several established designs, but beyond certain specifications, water hydrants, drinking fountains, garbage pits, and occasional seats were the innovations of the construction crews. Stone and logs were used effectively to create unique and truly rustic features. Water faucets and fountains were placed in unpeeled sections of log (of appropriate proportion and dimension). Garbage pits were covered with lengths of logs, stacked and affixed, with the center section cut and hinged to permit opening. Single rustic garbage cans were made of unpeeled log sections placed upright, the heartwood removed, with lids fashioned from an additional short log section. Occasional seats and benches were made from entire logs, hewn, or from half-logs fitted to form seats and backs, some having armrests of smaller unpeeled poles. Others were made of stone, sometimes built into a retaining wall. All seats and benches were built with the idea of rest, and many were placed in locations that afforded a pleasing or beautiful view. "Smoking spots," with a bench or seat and rustic log or stone ashtrays were similarly located.

Some campgrounds afforded playground facilities for children. Designed by Regional office architects, the equipment was constructed of poles, logs and planking, rather than metal piping. Swings, of the conventional variety, with wood slab seats or chairs were suspended from a pole framework. Swings utilizing a log of "interesting or grotesque shape" for the seat, with handles and footrests, were stoutly supported and well braced to withstand the longitudinal sway. In a few locations "monkey trees" were erected; yew trees, with foliage re- 
moved, sunk in the ground so that ten to twelve feet of branched trunk projected above ground level, with the top and tips of branches and all dead or dangerous limbs removed. Rockers, rocking horses, teetertotters and merry-go-rounds were other optional equipment. 89

Most campgrounds had registry booths to house a notice board and the campground registration book, located centrally where it was noticeable, but not inconvenient as an obstruction to activity. These small rustic shelters were of post and beam construction using logs and poles, or of native stone masonry, or frequently a combination of both. If a large shelter or community kitchen was included in the campground facilities, the registry booth repeated its design in smaller scale. Provided with benches or seats, and a secured writing surface, the booths afforded shelter from wind or rain for this necessary administrative function. In a few locations, the registry booth was combined with a comfort station, but this was found to be a less acceptable approach. 90

In some campgrounds rustic pump shelters and gazebos were erected. The Iron Mike Spring at Government Mineral Springs on the Gifford Pinchot National Forest presented an opportunity to enhance a popular local feature in such a way. The adjacent Little Iron Mike and Bubbling Mike springs were developed in an unobtrusive, natural way with landscaping to blend into the existing environment, but were not

${ }^{89}$ Forest Service, Recreation Handbook, Region Six, Plates 19H, 19J (Improvements Section).

$90 \mathrm{~A}$. D. Taylor, Report to the Chief, Forest Service On Trip of Inspection Through Some of the National Forests in Regions $1,2,3,4$, $5,6,7,8$, and 9,1936, p. 27 . 
enclosed or sheltered.

At Dead Indian Soda Springs on the Rogue River National Forest, a more formal approach to spring development was used. The spring itself was built up like a stone well, while the area immediately surrounding the spring was enclosed by a masonry wall with stone benches as part of the structural fabric. Triangular tables, the tops single stone plates, were located in two corners of the enclosure. Stone steps led up and down from the development, the upper approach forming an arched bridge over a sma11 stream.

With waters to cure or kill, such infrequent occurrences of nature as mineral springs were extremely popular with travelers and tourists, and were developed both as an attractive feature and a protective measure for the surrounding environment.

Still other campgrounds were developed beside small streams and creeks. Rustic footbridges of many varieties were placed to access campsites on the other shore, trails and scenic overlooks, and to insure safety in crossing. Some were simple footlogs, hewn to provide a flat walking surface, with a single pole handrail. Others were more complex constructions, two or three logs wide, with a plank surface, or half-round poles placed crosswise, and balustrade-like guard rails. Such bridges were inexpensive to build, attractive and appropriate to the environment, and a convenience for the public.

Al1 recreational improvements, campgrounds, picnic areas and trail heads were appropriately signed. Rustic entry signs were located prominently beside approach roads. Wood slabs, of varying dimensions, were supported by $\log$ or stone piers or suspended from $10 \mathrm{~g}$ gibbets, and 
identified the site by name. Often the U. S. Forest Service shield was incorporated in the design and the administering National Forest identified. Within the campground or picnic area, all facilities were clear1y designated, with directional and locational signs--appropriately rustic, noticeable but not excessively obtrusive. The standard Region Six "ten rule" sign which contained most of the precautionary remarks and the administrative regulations was to be placed in the registry booth or adjacent to the registry box, for public information and to minimize the number of signs placed in an area. ${ }^{91}$

Recreational structures and other campground improvements were to be painted or stained, not only to render them less conspicuous, but also to protect the materials, to prolong their utility and minimize too frequent replacement. French gray or silver gray shingle stains were the mediums of choice, although log structures could be left natural to weather or treated with a precise mixture of raw linseed oil, spar varnish and Burnt Umber ground in oil. 92

\section{Community Kitchens}

The most eloquent expressions of rustic architecture among the diverse forest improvements, and the most interesting from a sociological standpoint, were the community kitchens. Most closely adhering to Albert H. Good's definition of "rustic" design, they appeared to

${ }^{91}$ Ibid., p. 133. 92 Forest Service, Acceptable Building Plans, R-6 Insert Sheet,
p. A-206. 
"have been executed by pioneer craftsmen with limited hand tools."93 of $\mathrm{log}$, pole and masonry construction, the structural members were carefully proportioned to the natural setting. Log uprights corresponded in diameter to the measurements of the surrounding trees. Further, the effect was lost if the natural materials were too unblemished in their appearance; logs with knots and whorls were superior to smooth, clean poles. Foundations and masonry walls were styled to appear as "rough rock footings" or natural outcrops.

The use of rock presented certain problems. Boulders often gave the appearance of instability and their use was infrequent; irregularly shaped rock was preferable. Placed along their horizontal axis, uncoursed rubble stone resembled nature's bedding patterns, and more closely tied the structure to the ground.

Roof design was another challenge: roof pitch had to be compatible with potential snow load and other climatic conditions without establishing too great a vertical emphasis that would dominate a scene. Too, roofs had to achieve a proper proportion with the often massive nature of upright support members and footings. Oversized verge members helped resolve this problem as did the use of heavy shakes instead of shingles.

It is interesting to note the complete compatibility to environment achieved by these design standards. The character of the forest and climate surrounding the structure is directly reflected in its design, not only in the size of the structural members but also in the

93 Tweed, Soulliere, and Law, National Park Service Rustic Architecture, p. 93. 
degree of enclosure. Community kitchens on the western slopes of the Cascades are more frequently enclosed by heavy railings and even entire walls. Shelters illustrating this point are found at Eagle Creek Campground in the Columbia River Gorge (Mt. Hood National Forest), at LaWisWis Campground beside the Ohanepecosh River on the Gifford Pinchot National Forest, and in the Falls Creek Campground by Lake Quinault on the Olympic National Forest. Among these, however, there is variation in design and treatment. Eagle Creek Community Kitchen is enclosed by a vertical. board wall on the east elevation and by a solid stone railing; the LaWisWis Shelter is a rectangular structure with massive members and enclosed by a solid horizontal log railing; Falls Creek Community Kitchen is enclosed on each side by a high stone railing with massive buttress-like supports at each corner--but the effect is similar.

Ponderous and dark, the very success of design integrated with the environment resulted in a very qualified success in terms of use. People were disinclined to utilize the structures in inclement weather or in the failing light of evening because of their uninviting darkness. In contrast, the community kitchens located east of the Cascades in the open pine forests are lighter in construction, having pole railings or no enclosure. The structural members may be large but the effect remains that of openness and lightness commensurate with the surroundings. These community kitchens show much greater evidence of use, including more frequent defacement and vandalism. Also noticeable is the greater occurrence of repairs or replacement of materials. The community kitchens at Sawmill Flats and Boulder Cave Campgrounds on the 
Wenatchee National Forest, and the Poplar Flats Shelter on the Okanogan National Forest are good examples of the openness and lightness of east slope shelter construction.

Within the parameters of community kitchen design there was also a concerted effort to provide variety of appearance. No two shelters are exactly alike: if identical floor plans were used, then the elevation design differed substantially; if elevations were similar, then floor plans were altered to create a unique edifice. Two major plans emerged as effective and appropriate, rectangular and octagonal, but variations in roof shape and materials, elevation design, arrangement and number of stoves and fireplaces and in building materials prevented monotonous repetition. In unusual proximity, there are two octagonal community kitchens located in adjacent campgrounds on the Metolius River (Sisters Ranger District, Deschutes National Forest), but upon close examination, the shelters at Pioneer Ford and at Camp Sherman are found to be quite dissimilar. (See Appendix A, Deschutes National Forest, Sisters Ranger District: R6-01-04-DE-R4, R6-01-04-DE-R5.)

There were established criteria for the planning and construction of community kitchens, and approval of the Regional office was required. These criteria were based in part on the amount of use a recreational site received and upon the social customs of that area, whether the closest population centers supported a tight-knit community inclined to seek recreation in large groups or had active civic, service, or social organizations or church groups. Justification for construction also rested upon the climatic conditions, whether the area had frequent high summer temperatures with considerable direct sunlight, whether the area 
sustained a heavy annual rainfa11, whether the area had consistent strong wind conditions. 94

It is significant that the concept and construction of community kitchens, on Forest Service lands, is confined to the Depression era. Prior to that time, the Recreation Handbook specified that if a large shelter or community building was desired by a local population; it would have to be built by them under cooperative agreement with the Forest Service. Nonè were erected under these terms. Changing social custom and use patterns following World War II did not encourage the construction of additional similar buildings, and as some of the existing structures fell into disuse and disrepair, they were removed as safety hazards. Approximately forty-eight survive. In mapping their geographical distribution, a clustered pattern emerges: there are seven located on the Rogue River National Forest, eight on the Umatilla National Forest, nine on the Wenatchee National Forest, five on the Mt. Hood National Forest, and six on the Mt. Baker-Snoqualmie National Forest. Two Forests have two community kitchens each and five have only one remaining shelter. It is difficult to determine exactly how many were built, and also how many have been demolished, whether by official action, vandalism or by the cumulative effects of time and environmenta1 influence.

\section{Trail Shelters}

Trail shelters were constructed in remote locations, as a convenience to back country travelers. The primary design used in Region Six 132.

94 Forest Service, Recreation Handbook, Region Six, pp. 93, 128, 
was that of the Adirondack-type shelter, a salt box construction having two unequal gabled pitches, with three elevations enclosed and the fourth, the entrance, open. In timbered areas, these shelters were of pole or log construction with shake roofs and a variety of wood exterior wall materials including half-round poles (horizontal or verticai), vertical planking and wall shakes. They were simple, durable and functional, with no attempt at decorative treatment. In timberline areas or above, shelters were more frequently constructed of stone, with some interior timber support. Exposed to the harshest climatic conditions, and in some locations subject to avalanches and rock slides, the shelters were of the sturdiest construction. Because of the highly erratic weather patterns of their alpine environment, with sudden, often dramatic and dangerous changes in conditions, these shelters were safety precautions as well as traveler conveniences.

The Timberline Trail around Mt. Hood, on the Mt. Hood National Forest, was constructed by Civilian Conservation Corps crews, in fulfillment of a long-range plan to ópen this scenic area to greater public use. Several shelters were constructed, each conforming in material to its immediate environment, and placed at intervals convenient to an easy day's travel. Those shelters built below timberline were of log or pole construction, with shake roofs; those built above timberline were of stone, with timber reinforcement, and steeply pitched corrugated metal roofs.

In the intervening years, back country recreational use increased drastically, and the Timberline Trail, shelters, as other remote trail shelters, became focal points, often resulting in destructive overuse 
of an area. The shelters were subject to vandalism and their remoteness made regular supervision and maintenance difficult. For these reasons, many of the Depression-era trail shelters have been removed, while others have been heavily damaged or altogether destroyed by natural hazards. Because of the impact to sensitive timberline vegetation and to subalpine meadows, no attempt to rebuild or replace these shelters has been made. 
CHAPTER IV

EVALUATION

Be it enacted by the Senate and the House of Representatives of the United States of America in Congress assembled, that Congress finds and declares -

(a) That the spirit and direction of the Nation are founded upon and reflected in its historic past;

(b) That the historical and cultural foundations of the Nation should be preserved as a living part of our community life and development in order to give a sense of orientation to the American people. . .95

Mandated by Congress to preserve the cultural resources, both historic and prehistoric, within its jurisdiction, the U. S. Forest Service as a federal agency is committed to locating, identifying, protecting and enhancing them, to the greatest degree possible and administering them, "in a spirit of stewardship and trusteeship for future generations." 96

The administrative, protective and recreational sites and structures of the Depression era are the products of historic human activity, and as such are cultural resources. Identified and located in the inventory process, each has been described in detail (Appendix A). Assessment of their historical and architectural significance--to the Forest Service, to their localities, to the states of Oregon and Washington, and to the Pacific Northwest as a region--must proceed on

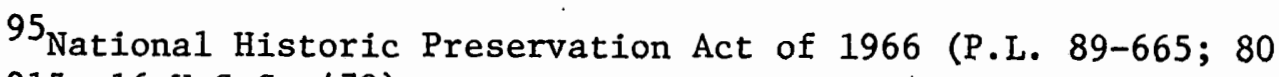
STAT. 915; 16 U.S.C. 470).

96 Executive Order 11593, Richard M. Nixon, May 13, 1971. 
the basis of that mass of data. Evaluation is a process of examination and judgment, of measuring the characteristics of an identified cultural resource against some standard. Significant cultural resources are those which meet the criteria for inclusion in the National Register of Historic Places: 97

The quality of significance in American history, architecture, archeology and culture is present in districts, sites, buildings, structures, and objects of State and 1ocal importance that possess integrity of location, design, setting, materials, workmanship, feeling and association and:

(1) That are associated with events that have made a significant contribution to the broad patterns of our history; or (2) That are associated with the lives of persons significant in our past; or

(3) That embody the distinctive characteristics of a type, period, or method of construction, or that represent the work of a master, or that possess high artistic values, or that represent a significant and distinguishable entity whose components may lack individual distinction; or

(4) That have yielded, or may be likely to yield, information important in prehistory or history. 98

Because the roughly $1,000-1,200$ remaining structures built by the Civilian Conservation Corps constitute approximately one-third of the Forest Service's standing installations in the Pacific Northwest Region, assessment of them as historic cultural resources is both incumbent and compelling. Future management directions will be based upon that evaluation. Most of the sites and structures are in continuing and constant use, although some are occupied only seasonally. Few are located in areas where their protection or preservation would impair other resource utilization. However, the varieties of work in-

97L. E. Wildesen, Cultural Resources Management Guidebook, 1977. 98 36 CFR 60.6. 
cluded in the responsibilities of the Forest Service are everincreasing and additional or expanded facilities are required. In many instances this might mean additions to or alterations of historic structures, or the introduction of new and possibly incompatible structures in an historic building group. In other instances, the most feasible approach to expansion might mean removal or demolition of historic structures.

All of the above alternative actions have occurred in the past. Unknown numbers of Depression-era improvements have been demolished or sold and removed; still more have been altered structurally, some to the point where little of their historic integrity remains; others have received only slight material alteration. Modern intrusions have been built in numerous Depression-era ranger stations and service compounds. The National Register criteria for evaluation exclude properties that have achieved significance within the last fifty years unless they are of exceptional importance to a community, state, region, or the nation. This is because the Register is intrinsically a compilation of the nation's historic resources worthy of preservation. The passage of some time is necessary to allow perceptions to be influenced by education, the judgments of previous decades, the dispassion of distance, and to better weigh the presence of enduring interest and value. The criteria do not describe "exceptional" because by its own definition, it cannot be fully catalogued or anticipated. The Depression of the $1930^{\prime}$ s made an extraordinary impact on the economic, political and social makeup of the nation, and the establishment of the Civilian Conservation Corps represented an important federal response 
to the Depression. In this context, the constructions of the Civilian Conservation Corps are interpreted to be of exceptional importance. Collectively they represent unique architecture in that the building programs and the times that motivated them no longer exist. 99

Rustic architecture also represents the distinctive characteristics of a period architecture, the expression of a design philosophy exclusive to twentieth century America. On National Forest System lands, rustic represents a design philosophy exclusive to the Depression era.

Subsequent design philosophies have supplanted rustic: concepts which include non-intrusiveness, but emphasize simplicity and structural honesty. They were ideas which, as they emerged in the late 1930's and early 1940's, were in line with changing economic conditions and new building materials. With increasing emphasis on efficiency and functionalism, rustic was viewed in some quarters as an affectation, deliberate and self-conscious, overly sophisticated, and romantic. Harmony with nature could be achieved as well through modest functional design with less cost in terms of labor and materials. 100

$99_{\mathrm{U}}$. S. Department of the Interior, Heritage Conservation and Recreation Service, How To Evaluate and Nominate Potential National Register Properties That Have Achieved Significance Within the Last 50 Years, by Marcella Sherfy and W. Ra- Luce, "How To" Bulletin No. 2 (Washington, D. C.: Summer, 1979), pp. 1, 3, 4, 5.

100 Tweed, Soulliere, and Law, National Park Service Rustic Architecture, p. 105. 
Rustic architecture is confined to the pre-World War II period because of labor and cost factors. Intensive labor projects became uneconomical, and even if affordable, the necessary expertise in stonemasonry and log building was no longer abundantly available. The values of solid and quality construction, and pride of skill and craftomanship in work well done are reflected in the Depression-era constructions of the Civilian Conservation Corps on the National Forests of the Pacific Northwest Region, and in a sense, symbolize a past way of life. These structures possess an integrity of materials, workmanship, feeling and association that is undiminished by the passage of time. The end products of a massive and unprecedented federal relief program, these structures also represent the reclamation of an important resource--the idle youth--and the recovery of essential skills and self-respect of men otherwise unemployed and discouraged.

The recreational sites, the campgrounds and picnic areas and the associated structures, the shelters and community kitchens, reflect the values and expectations of the visiting public of that day. Each campsite provided a sense of safe isolation in a forest environment, an outdoor experience not possible in the sheltered confines of civilization. Of the suitably rustic furnishings constructed by the Civilian Conservation Corps, few remain. The tables, benches and occasional seats made of logs were inexpensive to produce and sturdy, but finite when exposed to repeated seasons of weather and heavy and sometimes careless use. The stone stoves, capricious even when new and often inefficient, suffered at the hands of impatient campers, and many have been removed. Garbage pits, however cleverly disguised, and log 
garbage cans, failed to meet more modern standards of sanitation and refuse disposal as did the rustic pit toilets.

Some of the stone and $\log$ water hydrants and drinking fountains survive, but the wood is now deteriorating from excessive moisture and exposure. Many of the trail bridges, the foot logs, the stone arch spans, and the cable suspensions have been damaged so heavily by flooding and other natural conditions that their continued presence became a safety hazard.

The campgrounds themselves have been expanded, and often the maintenance records are the only means of identifying such historic developments. Little or no trace of the Depression-era design or landscaping remains. Changing use patterns and expectations have altered campground design concepts, and older areas have been improved to meet the needs of campers and other recreational vehicles. Camping remains a popular form of recreation, perhaps enjoyed by many more people today than ever before, but the quality of experience has evolved from secluded tent sites in primitive surroundings to more open spaces with paved access roads and modern conveniences. The pace of recreational activity has accelerated as we11, leaving the leisurely ambiance of a Depression-era setting an anachronism.

The trail shelters are no longer remote and heavy traffic, overuse and vandalism have in many instances provoked the removal of such focal points. As a category of Depression-era constructions, the trail shelters are perhaps the most threatened. Increasing use and awareness of its impact on the natural environment, particularly in fragile meadow areas, have necessitated re-evaluation of their desirability. 
A broad-brush regional evaluation of the Depression-era sites and structures would indicate collective merit on the basis of their obvious association "with events that have made a significant contribution to the broad patterns of our history." They also clearly embody "the distinctive characteristics of a type, period, or method of construction."

Beyond this, each site and each structure must be assessed as to the degree of integrity of location, design, setting, materials, workmanship, feeling, and association it retains. Each ranger station, service compound and work center must be considered as a unit or district as well, to determine what qualities of ensemble character survive, and whether the site retains its integrity as a whole. This does not mean to imply that a historic structure, materially or even structurally altered, or a historic building group now incorporating modern intrusions, is not eligible for inclusion in the National Register of Historic Places. Eligibility depends upon the degree of alteration or intrusion, but more upon the quantity and quality of original fabric remaining identifiable and intact.

Geographic distribution and number of a particular kind of structure may be considered among additional criteria in making a regional evaluation, but cannot be defined as absolutes. Far too often, each structure of a general type reveals a distinctive design, a varying kind of construction, and architectural features or decorative detailing that render it unique, and therefore less expendable. These unique features or details reveal the complexities of rustic architecture, and become express values to be preserved. 
Few of the surviving structures have extant working plans and specifications of construction which identify the designing architect. Too few identified designs and plans remain to discern the distinctive styles of the several known architects, and thus the remaining structures' designs cannot be ascribed with impunity. The names or initials of Linn A. Forrest, E. U. Blanchfield, W. J. Pollock and H. L. Gifford appear with greatest frequency, and certain features and details also coincide, but not in sufficient quantity to make qualified determinations. 101

While uniformly sensitive and compatible, many designs are unexceptional in character. Others, however, possess real excellence of design, are striking in their use of materials and shapes, and correct in the utilization of planning principles. These outstanding structures represent the work of a master and also possess high artistic values. Specific examples of design excellence and particular quality of execution are the Glacier Ranger Station office and the Monte Cristo Ranger Station on the Mt. Baker-Snoqualmie National Forest and the Bly Ranger Station on the Fremont National Forest. The latter is a compound possessing remarkable integrity of design and materials, interior as well as exterior. It is the only Forest Service facility in Region Six to have stone as its primary exterior wall material, and retains strong ensemble character.

The preliminary inventory of Depression-era sites and structures has raised more questions, than it has answered. Thus, these cultural

${ }^{101}$ Other initials appearing on drafts and plans are C.T.H., J.E.K., A.U.W., and K.E.B. 
resources possess considerable potential for non-consumptive research in many facets of this fascinating and disturbing period of history. The economic, social and political ramifications of the Great Depression have yet to be fully explored. It is clear that the records, maps, and photographs of the U. S. Forest Service represent a virtually untapped source of regional history, as it is also evident that the alumnae of the Civilian Conservation Corps, now employed by the Forest Service, or since retired, possess much relevant information. It is in their experiences and memories that the history of this period resides. Not all of the surviving Depression-era sites and structures meet the criteria for inclusion in the National Register of Historic Places. Neither do they possess particular interpretive or scientific values, but they continue to serve utilitarian functions and in that sense have a certain economic value which might bear consideration if removal or replacement were proposed. The costs of new construction, including materials and labor, very of ten exceed those of repair or rehabilitation. The qualities of materials and craftsmanship are not often duplicated, and greater quantities of time and energy are expended.

As the end products of an important federal response to the Depression, the constructions of the Civilian Conservation Corps are associated with events that have made a significant contribution to the broad patterns of our history, and are thus historically significant to the Pacific Northwest and to the nation. Because they embody the distinctive characteristics of a type and period, the rustic buildings on National Forest System lands in the Pacific Northwest Region are signi- 
ficant in American Architecture: many exhibit excellence of design and possess high artistic values. With few exceptions, the surviving districts, sites, buildings, structures and objects constructed by the Civilian Conservation Corps retain their integrity of location, design, setting, materials, workmanship, feeling and association, and therefore are found to be eligible for the National Register of Historic Places. They are worth preserving. 


\section{CHAPTER V}

\section{MANAGEMENT}

Un1ike the natural assets of our common wealth, timber, forage, wildlife and water, cultural resources are non-renewable. Those that are lost, by thoughtless or ignorant act, by deliberate decision, or through the cumulative effects of time and environment, cannot be reproduced or regenerated. Many of them by their very nature and fabric are finite.

Federal agencies are charged with the responsibility of administering those cultural resources in their custody in a spirit of stewardship and trusteeship for future generations. Management of cultural resources is an involved process, and as yet an unclearly defined one. Inventory is only the first step of that process: by identifying, defining, describing and recording the locatable resources, the resource base is delineated. Evaluation is the second phase of management, wherein the cultural values of the resource base are specified. When assessment is completed, management direction is set. All programatic requirements must be carefully analyzed; cultural resource exigencies must be related to other resource needs and to the obligations of recreation planning and facility management and integrated into the Forest management plan. It must be determined how best to utilize and protect the values inherent in the cultural resources. 
It is in the step of setting management direction that management objectives are established. Cultural resources differ in utility, aesthetic and interpretive significance. Therefore, management objectives for each will also differ accordingly. Planning decisions must be based on other considerations as well: the isolation of a resource, and conversely, its public access; the number of publics having access to the resource and their interests; its association with other cultural resources and its association with other opportunities that relate to it; possible or probable hazards; and how the management plan will relate to the objectives of the statewide cultural resources plan.

Management objectives such as preservation, conservation, rehabilitation, restoration, reconstruction, adaptation and destruction each have conditions and limitations that make general adoption for all resources impractical. However, alternative, simultaneous, or sequential objectives may be established for a single but complex resource such as a historic recreation sițe or building group.

Management consists of the activities of caretaking and utilization. The level of management activity is predicated on the objectives set in the management $\mathrm{plan}$, just as the management objectives are based on the values and importance of the resources. Caretaking, at whatever level of intensity, includes the functions of superintendence, naintenance, protection, and regulation. Utilization may include research, both data recovery (consumptive) and data study (non-consumptive) or the study of folk 1 ife and folk ways evident in the visitation or occupation of long established recreational areas, as well as direct and active use of a historic site or structure. Cultural values may be utilized in the 
development of interpretive programs which could include brochures and guidebooks, trails, audio-visual presentations, exhibits, signs, talks and tours. Some historic cultural resources lend themselves to demonstrations, living history and visitor participation. Because enhancement of cultural resources is a mandated management responsibility, interpretation is an important adjunct of a cultural resources program, and an effective management alternative.

Continued like use is another alternative, and a particularly viable one for the inventoried Depression-era sites and structures. However, eligibility for and inclusion in the National Register of Historic Places requires that the resource be maintained in such a way as to protect its historic integrity. This means that care should be taken to repair damaged or deteriorated material if possible, and to replace damaged or deteriorated material with 1 ike kind and technique if repair is not possible. Such maintenance can be costly in terms of time, labor and materials.

Because many of the Depression-era structures are eligible properties, and because they are rarely isolated individual buildings, the scope of expenditure for such exacting maintenance--for a single ranger station compound, for a single ranger district, for a single National Forest--must be realized.

Other considerations must be brought into the discussion as we11, factors which might influence the reassessment of budgetary priorities. While most of the Depression-era buildings are as yet structurally and materially sound, some of the service buildings are spatially inadequate to meet the present and future needs of the Forest Service. Many lack 
sufficient insulation to make them comfortable for year-round work and others have deficient plumbing and wiring. Maintenance to preserve the integrity of a structure's historical fabric also seems to imply that no additions or alterations are acceptable. Such is not actually the case. Compatible additions may be made to structures eligible for or included in the National Register, although this entails a separate process of compliance with federal statutes and implementing regulations. Compatibility is achieved through the use of similar design and exterior materials appropriate to continuity of texture and appearance. An acceptable addition would also be one that if removed would leave the essential identity of the original structure unimpaired. By nominating to the National Register only the intact exterior of an eligible Depressionera structure, the interior fabric may be altered in whatever way is necessary to achieve more efficient spatial organization or to improve insulation, wiring or plumbing. Carefully considered, it may be more cost effective to maintain a sound historic structure than to replace it altogether.

Adaptive. reuse is a similarly suitable management alternative for some of the Depression-era structures. Changes in administrative practices have left guard stations without specific function. Formerly protective sites, many are no longer needed in that capacity and are unoccupied. Until declared excess property, they must be maintained as an unused investment. Those located adjacent to recreational areas and campgrounds might be utilized in the Forest's campground host program or as visitor information service centers. In some instances, it might prove to be more economically feasible to remove an unused building to a 
location where such a structure was needed than to build a new one. Rehabilitation is a management alternative as well as a management objective. It involves stabilizing a damaged or deteriorated structure and restoring it to a useful condition. To do this may require replacement of structural members as well as material fabric, and to do so may be somewhat expensive. It does, however, represent an acceptable mitigation of the adverse effect of demolition by neglect. If the structure has utilitarian values as well as historic, architectural, aesthetic and interpretive qualities, it is incumbent upon the Forest to rehabilitate it in fulfillment of statutory and regulatory responsibilities.

Restoration, too, is a management alternative, and is defined as the re-establishment of the structure's form and appearance at a given time. In the case of Depression-era structures, this would most appropriately be its original form and appearance. Restoration must be based on historical fact, documentary and pictorial evidence, rather than on speculation or even probability. Alteration of the historic fabric and design is preferable to restoration lacking authenticity, as restoration is neither mandatory nor recommended.

Reconstruction is a possible management alternative, but its adoption is dubious. Reconstruction entails the faithful and accurate replication of an absent site or structure. Although there might be occasion to reconstruct a historic building, the primary values associated with the original structure's historicity would be lacking, and the appropriateness of the project questionable. 
One other management alternative is complete documentation of a resource through intensive research and data collection, photography and measured drawings. By these means all possible values of a resource are extracted, recorded and added to the body of historical knowledge. This becomes the alternative of choice where there is unresolvable resource conflict and greater priority is attached to the other resource. 
CHAPTER VI

CONCLUSION

In November and December, 1941, a Joint Committee held hearings on the continuation of the Civilian Conservation Corps. Despite its value as a training agency, it was generally perceived as a relief agency. With rapidly rising employment rates and dwindling enrollment in the Corps, it was difficult to justify extension of the program. On December 24, 1941, the committee recommended that the CCC "be abolished - . not later than July 1, 1942."102

A bill providing for the abolition of the CCC was introduced by Senator Kenneth McKellar of Tennessee, but it was never reported from the committee. President Roosevelt then seized the initiative and asked for an appropriation for the Corps for fiscal year 1942-43. The House Committee on Appropriations voted on June 3, 1942, not to comply with the President's request. On June 5, 1942, the House, by 158 to 151, voted not to appropriate further money for the CCC, but instead to provide $\$ 500,000$ for its 1iquidation. The Senate repudiated the House's action on June 26, but rescinded its own action on June 30,

${ }^{102}$ Preliminary Report of the Joint Committee on the Reduction of Nonessential Federa1 Expenditures, Congress of the United States, $77^{\text {th }}$ Congress, First Session, Document 152 (Washington, 1941), p. 4, as cited in Salmond, The Civilian Conservation Corps, p. 212. 
when the House agreed to appropriate $\$ 8$ million for the liquidation of the CCC. The Civilian Conservation Corps was terminated. 103 with the demise of the CCC, the Forest Service building program ended.

The Civilian Conservation Corps was frankly experimental, having no real precedent to follow and no long-term goals to be reached. Despite its successes, its potential was never fully tapped. Its specified function of providing useful conservation work for unemployed young men was, however, fulfilled. The trees planted or protected, the acres saved from soil erosion, the range lands restored, and the recreation areas developed are a permanent testimony to the success of the Corps' work. 104

The CCC also had a lasting effect on its enrolless, tangible benefits to the health, educational level, and employment expectancies, as well as giving immediate financial aid to their families. The enrollees derived intangible benefits also, such as a new understanding of their country and a faith in its future. 105

Rustic arthitecture was a function of its own time, and ideally suited to the conditions of a distressed economy and wide-spread unemployment. Labor intensive, rustic architecture employed the combined efforts of many men, skilled and unskilled, in planning, preparing and building. Yet it was also economical in that it employed the use of natural and native building materials, certainly locally abundant for little or no cost.

$$
\begin{aligned}
& 103_{\text {Salmond, pp. } 212-217} \\
& 104_{\text {Salmond, pp. } 220-221} \\
& 105_{\text {Ibid., p. } 221 .}
\end{aligned}
$$


In excess of one thousand Depression-era sites and structures survive in the Pacific Northwest Region. Most of them retain sufficient integrity as to be readily identifiable as products of the Civilian Conservation Corps. Many of the rustic structures possess a rare and distinctive beauty; others exhibit only the sturdy qualities of design and construction typical of that day. Whether refined or rugged, plain or highly stylistic, rustic architecture, inclusive of landscape design, represents a uniquely American expression of twentieth century architectural thought. It was an expression largely confined to the Depression era, and its presence enriches the cultural environment. Many such structures are gone as are most of the ingenious rustic fixtures, features and furnishings. What remains should be protected and conserved by whatever means available, but they should also be used and enjoyed. Continued like use, adaptive reuse and rehabilitation of salvageable structures are the recommended management alternatives. Most, though not a11, Depression-era sites and structures meet the criteria for inclusion in the National Register of Historic Places and will be nominated. It would be well to remember the work of the Civilian Conservation Corps: the Pacific Northwest and the Forest Service owe them a great debt for the timely development of recreation sites and construction of much-needed administrative facilities. Without that unprecedented federal relief program, once derided as "utterly visionary and chimerical,"106 the National Forests would not have been able to

${ }^{106}$ Arthur M. Hyde, Secretary of Agriculture, Hoover Administration, as cited by Arthur M. Schlesinger, Jr., The Age of Roosevelt, Vol. 1: The Crisis of the 01d Order - 1919-1933, p. 431. 
provide as many opportunities for outdoor recreational experience, physical activity, mental relaxation and visual pleasure, those values now almost taken for granted. 


\section{BIBLIOGRAPHY}

\section{PRIMARY SOURCES}

U.S. Department of Agriculture. Forest Service. Improvement Handbook, by Division of Engineering. Washington, D. C.: Government Printing Office, 1937.

U.S. Department of Agriculture. Forest Service. Acceptable Plans Forest Service Administrative Buildings, by Division of Engineering. Washington, D. C.: Government Printing Office, 1938.

U.S. Department of Agriculture. Forest Service. Technical Handbook Administrative Site Plans, North Pacific Region. Amended 6/20/52.

U.S. Department of Agriculture. Forest Service. Recreation Handbook. Part 1: Recreation Plans and Planning, by Division of Recreation and Lands, North Pacific Region. Revised 1945.

U.S. Department of Agriculture, Forest Service. Recreation Handbook. Region Six. Revised 4/10/33.

U.S. Department of Agriculture. Forest Service. Forest Administrative Site Plans. Region Six. 1935-1940.

U.S. Department of Agriculture. Forest Service. Camp Stoves And Fireplaces, by A. D. Taylor. Published by Emergency Conservation Work. Washington, D. C.: Government Printing Office, 1937.

U.S. War Department. Civilian Conservation Corps Regulations. Washington, D. C.: Government Printing Office, 1937.

McEntee, J. J. Federal Security Agency Final Report of the Director of the Civilian Conservation Corps, April, 1933 through June 30,1942 . No Date. (Typewritten).

Taylor, A. D. Report to U.S. Forester's Office On Trip of Inspection Through Some of The National Forest Areas In Regions $2,4,6$, and 1. 1935 .

Taylor, A. D. Report To The Chief, Forest Service On Trip of Inspection Through Some of the National Forests in Regions $1,2,3,4,5,6$, 7,8 , and 9 . 1936.

Seattle, Washington. Federal Records Center. General Services Administration. Record Groups FS 184, 185, 186, 187. Forest Inspection 
Reports. 1933-1942.

Washington, D. C. National Archives and Records Service. General

Services Administration. "C.C.C. Camps Approved For Winter

Period 1933-1934, State of Oregon".

Rogue River National Forest. Records and Work Schedules, CCC. 1933-

1942. Forest Supervisor's Office. Medford, Oregon.

Okanogan National Forest. Working Drawings and Specifications for

Structures at Early Winters Ranger Station. District Ranger's

Office, Winthrop Ranger District. Winthrop, Washington.

Ochoco National Forest. Working Drawings and Specifications for

Structures at Rager Ranger Station, Ochoco Ranger Station. Forest

Supervisor's Office. Prineville, Oregon.

Speciale, Faye. Portland, Oregon. Interview. 22 May 1979.

Pacific Northwest Region. U.S. Forest Service. Photograph Collections. Regional Office. Portland, Oregon.

Okanogan National Forest. Photograph Collections. Forest Supervisor's Office. Okanogan, Washington.

Rogue River National Forest. Photograph Collections. Forest Supervisor's Office. Medford, Oregon.

\section{SECONDARY SOURCES}

Leuchtenburg, William E. The Perils of Prosperity, 1914-32. Chicago: University of Chicago Press, 1958.

Leuchtenburg, Willian E. Franklin D. Roosevelt And The Kew Deal, 19321940. New York: Harper and Row, Publishers, Harper Colophon Edition, 1963.

Nixon, Edgar B., ed. Frank1in D. Rooseve1t And Conservation, 1911-1945. Vol. 1: 1911-1937. General Services Administration. National

Archives and Records Service. Franklin D. Roosevelt Library. Hyde Park, New York: 1957.

Salmond, John A. The Civilian Conservation Corps, 1933-1942: A New Deal Case Study. Durham, North Carolina: Duke University Press, 1967.

Schlesinger, Arthur Meier, Sr. The New Deal In Action 1933-1939. New York: The Macmillan Company, 1940. 
Schlesinger, Arthur M., Jr. The Age of Roosevelt. Vol. 1: The Crisis of The 01d Order, 1919-1933. Boston: Houghton Miffin Company. 1957.

Schlesinger, Arthur M., Jr. The Age of Roosevelt. Vol. 2: The Coming of The New Deal. Boston: Houghton Mifflin Company, 1959.

Schlesinger, Arthur M., Jr. The Age of Roosevelt. Vol. 3: The Politics of Upheaval. Boston: Houghton Mifflin Company, 1960.

Tweed, William C., Soulliere, Laura E., and Law, Henry G. National Park Service Rustic Architecture: 1916-1942. San Francisco: National Park Service, Western Regional Office, Division of Cultural Resource Management, 1977.

Wildesen, Leslie E. Cultural Resource Management: A Guidebook of Procedures and Techniques for Managing Historical and Archeological Resources. U.S.D.A. Forest Service, Pacific Northwest Region, 1977.

Williams, T. Harry, Current, Richard N., and Freidel, Frank. A History of the United States Since 1865). New York: Alfred A. Knopf, 1960.

"The C.C.C. Program 1933 To 1941, Wallowa National Forest". No Date. (Typewritten).

U.S. Department of the Interior. Heritage Conservation and Recreation Service. How To Evaluate And Nominate Potential National Register Properties That Have Achieved Significance Within The Last 50 Years, by Marcella Sherfy and W. Ray. Luce. "How To" Bulletin No. 2. Washington, D. C.: Summer, 1979. 


\section{APPENDIX A}

DESCHUTES NATIONAI FOREST

Sisters Ranger District

R6-01-04-DE-RI Suttle Lake Picnic Shelter: Rectangular, split shake salt box roof, poured concrete platform; peeled log construction with vertical $\log$ posts, round peeled pole brackets, peeled pole purlins and trusses; exterior of horizontal peeled logss saddle-notched corners, $\mathrm{NE}$ and $\mathrm{SE}$, battered ends, buttressed, above smaller vertical peeled poles with vertical boards, rounded ends, on gable ends above eave line; random-coursed rubble exterior chimney center east facade and interior center fireplace with side-facing stoves; west facade is open, $2 \% 3$ of north and south facades open, with $1 / 3$ north and south facades and east facade enclosed. No apparent alterations to interior or exterior. In very good condition.

R6-01-04-DE-R2 Suttle Lake Change Building: Rectangular, peeled pole frame, split shake medium gable roof, poured concrete platform; exterior wood shakes with vertical boards, rounded ends, on gable ends above eave line; door and window openings framed with half-round peeled poles. No apparent exterior alterations. In good condition.

R6-01-04-DE-R3 Suttle Lake Comfort Station: Rectangular, wood frame, poured concrete platform; split shake high hipped roof with small, slightly projecting gables on north, south, and west (main). elevations to shelter entrances. Exterior shakes with rounded vertical boards on gable pediments. Door and window openings framed with halfround peeled poles. Center entrance on west (main) facade for storage or possi- 
Sisters Ranger District

R6-01-04-DE-R3

bly intended original use for registry booth" access. No apparent exterior alterations. In very good condition.

$R 6-01-04-D E-R 4$

Pioneer Ford Picnic Shelter: Octagonal, peeled log construction, eight large vertical log posts, three peeled pole horizontals form railing; concrete platform --ground level; center random--coursed rubble chimney with two stoves; split shake roof. No apparent alterations. In very good condition.

$R 6-01-04-D E-R 5$

Camp Sherman Picnic Shelter: Octagonal, peeled log construction, eight large vertical log posts, three peeled pole horizontals form railing ends notched to fit into vertical posts; slightly raised concrete platform; center random coursed rubble chimney with one large stove (south) and open hearth fireplace (west); split-shake roof. Certain of large eave logs retain bark (ponderosa pine), may be replacements; some of horizontal pole railings missing; some of roof shakes missing. In good condition.

R6-01-04-DE-R6 Pine Rest Picnic Shelter: Rectangular, peeled log construction with ten vertical posts interspaced with three horizontal peeled poles to forn railing. Slightly raised concrete platform; split shake high hipped roof with pole ridge weather proofing. Exterior cut and fitted random coursed stone chinney, rusticated surface, center, east elevation, open hearth fireplace, two side-facing stoves (center, rear, interior). No apparent alterations: In very good condition. 
DESCHUTES NATIONAL FOREST

Crescent Ranger District

R6-01-02-DE1

Crescent Lake Guard Station: Completed 1933 by CCC; T-shaped, wood frame, concrete pier foundation; hipped gable roof with hipped cross gable; extended cross zable on east forms porch roof. Wood shingle roof; horizontal clapboard exterior with vertical boards, rounded ends and battens on all gable ends. Six-oversix sash windows, singly and in combinations with mullions. Single brick chimney, off-center on west slope of roof. No apparent exterior alterations. No decoration. In very good condition.

R6-01-02-DE2

Crescent Ranger Station Warehouse: Rectangular wood frame, wood shingle medium gable roof, concrete foundation; horizontal shiplap exterior wood corner trim; five reinforced diagonal board loading doors, slide opening; nine-light single sash windows. Shed roofed lean-to addition to length of rear elevation. No decoration.

R6-01-02-DE3

Crescent Ranger Station Bunkhouse: Built 1930 's, removed to present site from Cabin Lake in 1949; rectangular, wood frame, wood shingle high gable roof; cement block foundation. Horizontal shiplap exterior, wood corner trim. Off-center gabled hoods on west (main) and east facades. Horizontal six-light single sashes, functional plain shutters. No obvious exterior alterations. No decoration. 
FREMONT NATIONAI FOREST

B1y Ranger District

R6-02-02-DE1

Bly Ranger Station, Old Office \#2000:

1936; 962 sq. ft.; I-shaped, 3-roon

office, 1 story wood frame, mediun gable roof, intersecting gable off-set with gabled hip, wood shingled. North roof slope, extends bell cast to form porch roof, supported by two squared timber posts, round flush brackets and a stone post with buttress; south roof slope extends, straight, to cover rear entry. Stone chimney, off-set on south (rear) slope of roof. Stone exterior, coursed rubble of varying sizes and shapes, natural surface; red and green rhyolite and gray basalt; horizontal clapboard on north wall beneath porch roof. Vertical boards, angular cut, and battens on gable ends and on gablet. Six-over-six double hung sash windows, flanked by decorative shutters exhibiting a simple pine tree cut out. Curving rock buttress at each corner and on north face of porch post. Single simple pine tree cut out centered on each gable end. Doors exhibit a "rough plank" exterior with hand forged latches and latch plates. Interior somewhat modified--ceiling material replaced, fluorescent lighting fixtures added entry hall altered. Knotty pine wall materials, knotty pine surface on interior doors. Hand forged latches and plates. Well maintained, in excellent condition; slightly altered materially on interior but does not greatly detract from integrity.

$\mathrm{R} 6-02-01-\mathrm{DE} 2$

Bly Ranger Station, D.E.A. Residence \#1004: 1941; 936 sq. ft.; T-shaped, 4room dwelling, 1 story wood frame, poured concrete foundation, baseinent. Woodshingled medium gable, projecting center gable, north facade. Stone exterior, coursed rubble of dissimilar shapes and sizes incorporating red and green rhyolite gray basalt, occasional brick, corners not buttressed; vertical boards, angular cut and battens on all gable ends. 
Bly Ranger District

R6-02-01-DE2

R6-02-01-DE3
Six-over-six double-hung sash windows flanked by decorative shutters, single well-shaped complex pine tree cut out. Single, large well-shaped pine tree cut out centered on each gable end. Uncovered entrance centered on south gable end; main entry recessed, off-set on center gable, porch roof supported by two large squaredtimber posts, with short, rounded flush inset brackets, posts are hand-routed with chisel. Knotty pine interior, little alteration.

Bly Ranger Station, Ranger's Residence \#1002: 1936; 1505 sq. ft.; T-shaped, six room dwelling, 1 story wood frame, poured concrete foundation, basement, woodshingled medium gable roof, gabled hip on north gable end, off-set gable projects from east facade with bellcast eave forming roof over semi-enclosed entry supported by buttressed stone pillars, squaredtimber lintels distressed by adze to appear hand-hewn, short, rounded flush brackets, semi-circular arch window opening in stone porch wall, north hip extends to cover rear enclosed entry, exterior vertical board and batten. Exterior end chimney coarsed rubble, varying, on south gable end; stone interior chimney off-set on west roof slope.

Stone exterior wall material to eave line, vertical board, angular cut, battens on gable ends, gablet, and rear enclosed entry, also on projecting bay on west facade. Decorated mullion window with six-over-six double-hung sash flanked by four-over-four sashes, surmounted by transom lights center, off-set east gable; six-over-six double-hung sash windows flanked by decorative shutters each with single simple pine tree cut out. Single large, well formed pine tree cut out centered south and east gable ends. Knotty pine interior, unaltered high ceiling with squared-timber beams and two trusses, hand-routed, and distressed with adze in living room, window seat flanked by built-in bookcases. Stone fireplace, 
Bly Ranger District

R6-02-01-DE3

pine-tree cut and fitted in center as cartouche; hand-forged wrought-iron chandelier, two small hand-made wallmounted light fixtures. Wood-pegged wood cornice trim, knotty pine wall material; open structural door opening, squaredtimber lintel adze-distressed, scrolled, short, rounded inset flush brackets. Dry masonry wall, cement steps, retain short natural slope and access house. Shorter, less extensive dry masonry wall retains a second slope rise and stone steps access a lawn area above house on west. No significant structural or material alteration. Excellent condition.

R6-02-01-DE4

Bly Ranger Station, T.M.A. Residence \#1003: 1937; 1140 sq. ft.; T-shaped, 5room dwelling, I story wood-frame, poured concrete foundation, basement, woodshingled medium gable roof, intersecting cross gable, off-set with gabled hips; east (front) wall recessed to form porch, roof supported by buttressed stone pillar, squared-timber posts with short, rounded flush brackets. Stone interior chimney offset on west slope of main gable. Stone exterior wall material to eave line, coursed rubble, varying dimensions, red and green rhyolite and gray basalt; vertical boards, angular cut, battens on gable ends and gablets, enclosed rear entry, exterior board and batten. Decorated mullion window with six-over-six double-hung sash, flanked by four-overfour sashes and surmounted by transoin lights, center, north gable end; six-oversix double-hung sash windows, flanked by decorative shutters each having a single well-shaped complex pine tree cut out. Single large, defined pine tree cutouts centered on each gable end. Knotty pine interior, unaltered, high ceiling, open beams and two trusses, adze distressed and hand routed. Stone fireplace, cut and fitted pine tree cartouche. Open door openings with scrolled lintels, shortrounded flush brackets. Dry masonry wall extends along lower reach of short natural 
Bly Ranger District

R6-02-01-DE4

R6-02-01-DE5

R6-02-01-DE6

R6-02-01-DE7 slope to west of house. No significant structural or material alteration. Excellent condition.

Bly Ranger Station Garage \#1501: 1936; Rectangular 4 bay structure, 1 story wood frame, dirt floor. Gabled hip roof, wood shingled. Stone esterior wall material gray basalt cut in narrow irregular shapes, coursed, to eave line, buttressed corners; vertical board and batten on gablets. Six-vertical-light sashes flanked by decorative shutters, each having a single simple pine tree symbol, similar simple pine tree centered on each gablet. South facade has four large, vertical-"rough sawn" plank doors, slide opening; three hand-routed squared-timber supports. No apparent alterations, excellent condition.

B1y Ranger Station, Warehouse \#2201:

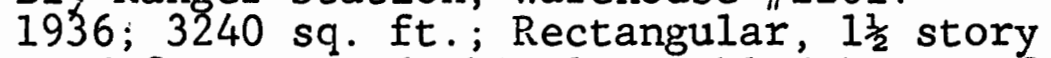
wood frame, wood-shingled gabled hip roof. Four bay structure, stone exterior wall material to eave line of red and green rhyolite and gray basalt, buttressed corners, vertical board and batten on gablets and on two small projecting gables --enclosed rear entries. Interior stretcher bond chimney, exterior end offset, south slope above hip. Mullion windows with eight divisions of nine lights each, also two and four divisions of nine lights each; two nine light sashes in each gablet. On east facade, three large slide-opening doors, each folding, twoleaf, extending to eave line, small twoleaf, wood-panel door, hinge opening. Crude pine tree design of green rhyolite stone, cut and fitted on northeast corner, facing east, above center on pillar. Interior altered, exterior--no apparent structural or material alteration:

Bly Ranger Station, Gas and Oil House \#2500: 1936; 337 sq. ft.; Rectangular, wood-frame, wood shingled medium gable roof extending to cover service area and 
Bly Ranger District

R6-02-01-DE7

R6-02-01-DE8

R6-02-01-DE9

Bly Ranger Station, Post and Rail Fence: 1936-37; defines northern, southern and western limits of Forest Service property. Squared-timber posts, 3 feet, three horizontal 1 x 4 board rails notched into posts. Some repairs, rails reaffixed.

R6-02-01-DE-RI

Sprague River Campground: Now used as picnic area only; a few campsites remain relatively intact; spacious, partially screened with natural vegetation, seclude. ed. No stoves extant. Foot bridge with stone embankments constructed of two logs laid across river, planks across base logs serve as walking surface. Plain 
Bly Ranger District

R6-02-01-DE-R1 hand railing of peeled posts and rails extends length of bridge on upstream and downstream sides. At one end of bridge, stone side steps with flaring solid rail ing (stone) access river bank. Stone masonry includes river cobbles as well as irregular basalt. No obvious structural alterations to bridge or stairs. Structure will need repair, reinforcement or replacement of materials soon if to be maintained. 
FREMONT NATIONAL FOREST

Paisley Ranger District

R6-02-03-DE1

Paisley Ranger Station Office \#1055:

1937; L-shaped, 1 story wood-frame, poured concrete foundation with coursed, small squared-rubble masonry veneer, wood-shingled low gable roof, two off-set gables on north (main) facade, westernmost gable projects. Horizontal clapboard exterior on north facade between off-set gables, on east elevation of projecting off-set gable, on portions of south facing rear elevation and on all gable ends except projecting off-set gable. Two elevations of projecting offset gable are faced with coursed, sinallsquared-rubble masonry using native stone of varying shades of gray (light, medium, dark) and red in a randoin pattern. Sixover-six double-hung sash windows, flanked by decorative vertical plank shutters, each having a simple pine tree cut out above center to the outside. Original vertical board and batten exteriors on gable ends and portions of south facade replaced with vertical boards, battens of almost equivalent width.

R6-02-03-DE2

Paisley Ranger Station, Ranger's Residence \#1014: 1937; T-shaped, 1 story wood-frame, poured concrete foundation wood-shingled low gable roof, with projecting off-set cross-gable, small lowgabled porch centered on east gable end. Horizontal clapboard exterior to eave line on north, south and east elevations, on cross-gable ends and above eave line on west gable end. Mullion window with five divisions of twelve-lights, eightover-eight and six-over-six double-hung. sash windows flanked by decorative vertical plank shutters, each having a single simple pine tree cut out above center and to the outside. Original vertical board and batten exteriors below the eave line on the cross-gable ends and west elevation and on the east gable end above the eave line have been replaced with vertical boards with broad battens. 
Paisley Ranger District

R6-02-03-DE3

Paisley Ranger Station, Ranger's Residence Garage \#1520: 1937; Rectangular, wood-frame, wood-shingled low gable roof, east slope of roof extends to cover storage area giving a salt-box appearance from rear. Lean-to is part of original structure. Original horizontal clapboards on uppermost extent of gable ends; vertical board and batten replaced by vertical boards, broad battens overlaid. Two large vertical-board slide opening. doors access north gable end. No decoration.

R6-02-03-DE4

Paisley Ranger Station Barn \#1015: ca

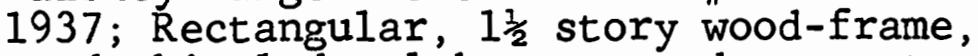
wood-shingled saltbox, poured concrete foundation. Horizontal clapboard exterior, ground story level east, west and south elevations, vertical board and batten on gable ends and upper level north (main) facade, ground story north facade has coursed, squared-rubble masonry veneer. Mullion windows having pairs of four light sashes, and one-over-one doublehung sash windows. No decoration. Barn converted to use as duplex residence necessitating some structural and material alteration.

R6-02-03-DE5

Paisley Ranger Station Warehouse \#2202:

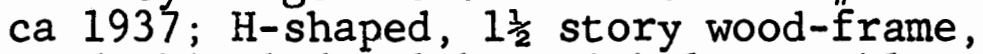
wood-shingled saltbox with long gable slope on north center wall recessed forms two projecting bays. Horizontal clapboard exterior to eave line, vertical board and batten on gable ends, coursed, squared-rubble masonry veneer on northfacing recessed facade. Twelve-light sashes in combinations with mullions. No decoration.

R6-02-03-DE6

Paisley Ranger Station Equipment Shop \#2203: ca 1937; Rectangular, wood-frame, wood-shingled saltbox, poured concrete foundation. Horizontal clapboard exterior, vertical board and batten on gable ends. Three bays in length, three large paneled doors on north (inain) facade, two 
Paisley Ranger District

R6-02-03-DE6

slide-opening, one vertical lift large diagonal board, reinforced, slide opening door center west gable end. No decoration. Shed-roofed open storage added to east gable end; addition to west and south elevations, vertical board exterior, for district tree cooler, resulting in substantial alteration of structure and roofline.

R6-02-03-DE7

Paisley Ranger Station Gas and Oil House \#2502: ca 1937; Rectangular, wood-frame, poured concrete foundation, wood-shingled low gable roof; east (front) wall is recessed to form porch, supported by large squared-timber posts. Vertical board and batten exterior, horizontal clapboard on gable ends. Mullion windows with three sashes each, nine and twelve lights. No decoration. No obvious exterior alteration. 
FREMONT NATIONAL FOREST

Silver Lake Ranger District

R6-02-04-DE1

Squaw Springs Water Development: Series of interconnected troughs made from logs by process of drilling, burning and hollowing interiors, each trough approximately five feet in length, proceeding east and west from spring source. Also a longitudinal series of rectangular, boxtype troughs of rough dimension planking, each approximately ten feet in length. Troughs are approximately eighteen inches in height.

R6-02-04-DE2

Alder Spring Water Development: Series of interconnected troughs made from hollowedout logs of medium diameter, approximately twelve feet in length. Longitudinal progression of troughs proceeds west from Alder Spring. 
GIFFORD PINCHOT NATIONAL FOREST

Mt. Adams Ranger District

R6-03-03-DE1

it. Adams Ranger Station, Residence

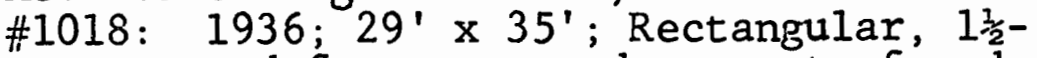
story, wood-frame, poured concrete foundation, wood-shingled high gable roof, major off-set gable on south (main) elevation, center gable porch, north (rear) elevation. Random rubble interior chimney, stone cap, center, south slope main gable. Horizontal clapboard exterior, vertical boards, angular cut, on all gable ends. Six-over-six double-hung sash windows, singly and in combinations with mullions. Main entry, off-set, recessed on south gable end, supported by single large squared-timber post. No decoration. Some sash windows replaced by aluminum casements on ground level, north elevation.

R6-03-03-DE2

Mt. Adans Ranger Station, Foremen's Quarters \#1300: 1938; 26' x 60'; Rectangular, 1-story, wood-frame, poured concrete foundation. High gable roof, center gable porch, supported by four $4 \times 4$ posts on north gable end (main) facade. Wall shake exteriox. Fourlight sash windows, singly and in combinations with muliions. No decoration. Roof material, textured metal.

R6-03-03-DE3 Mt. Adams Ranger Station, Residence Garage \#1500: 1940; 20' x 26'; Rectangular, wood frame, medium gable roof.

Horizontal clapboard exterior, vertical boards, angular cut, battens every other board on gable ends. Mullion window, three divisions of six lights each on south gable end. Single vertical lift vehicle door, north gable end; single leaf, wood panel door off-set, south gable end. Single distinctive pine tree cut out, slightly above center on each gable end. Textured metal roof material.

R6-03-03-DE4 Mt. Adams Ranger Station, Residence Garage \#1507: 1934; 16' $\times 18^{\prime}$; Rectangular, wood frame, poured concrete founda- 
Mt. Adams Ranger District

R6-03-03-DE4

R6-03-03-DE 5

R6-03-03-DE6

R6-03-03-DE7

R6-03-03-DE8

tion, wood shingled mediun gable roof. Horizontal shiplap exterior, end boards, structural door opening for one vehicle, off-set west gable end; structure internally divided for storage. No decoration.

Mt. Adams Ranger Station, Residence Garage \#1607: 1934; 16' x 24'; Rectangular, wood-frame, poured concrete foundation, medium gable roof. Narrow rounded shiplap exterior. Bracketed verges. Center vehicle door, north gable end, vertical lift. No decoration. Textured metal roof material, garage door, recent alterations, structural alteration south gable end, materials replaced with like kind.

Mt. Adams Ranger Station, Woodshed \#1600: 1934; 14' X 16'; Rectangular, wood frame, concrete block piers, medium gable roof. Horizontal shiplap exterior, end boards. Verges bracketed. Single leaf slide opening door, center, north gable end. No decoration.

Mt . Adams Ranger Station, Equipment Storage \#2300: $1936 ; 30^{\prime} \times 122^{\prime}$; Rectangular, wood-frame (peeled pole), saltbox roof, dirt floor, ten bays in length, open on east elevation. Wall shake exterior. No decoration. Textured metal roof material.

Mt. Adams Ranger Station, Barn \#2400: 1920 ; 2160 sq. ft.; Rectangular, wood frame, gambrel roof, bellcast eaves. Horizontal shiplap exterior, end boards. Large slide opening door off-set, north gable end, single leaf door off-set opposite, smaller slide opening door, off-set mid-level north gable end. Four-overfour double-hung sashes, four-light single sash windows. Single leaf slideopening door, off-set south gable end, ground level, single leaf hinged door opposite; square hinged door centered above at mid-level. No decoration. Textured metal roof material. 
Mt. Adams Ranger District

R6-03-03-DE9

R6-03-03-DE10

Mt. Adams Ranger Station, Lumber Storage \#2800: 1936; 24' x 60'; Rectangular, wood frame, random rubble veneer, concrete foundation, dirt floor, saltbox roof, six bays, open, north elevation. Squaredtimber supports, dimension lumber brackets, mitered, affixed. Wall shake exterior. No decoration. Textured metal roof material.

Peterson Guard Station \#1006: 1926; 16 x 20; Rectangular $1 \frac{3}{2}$-story wood frame, concrete pier, hewn log sills, wood shingled high gable roof, hipped porch roof extends ground story width, west gable end, ground story wall, east gable end recessed, gable end extends to form porch, supported by four squared-timber posts. Exterior end chimney, coursed rubble, center, east gable end partially enclosed by extended gable (possible later addition). Horizontal shiplap exterior, end boards. Vertical board door, reinforced, off-set on each gable end. No decoration.

R6-03-03-DE11

Peterson Guard Station, Woodshed: Rectangular, wood frame, stone pier foundation, wood shingled high gable roof. Wood shingle exterior. Shingled door, single leaf, off-set on east gable end. No decoration.

R6-03-03-DE12

Willard Garage \#1511: Rectangular, wood frame, two bay, dirt floor, wood shingled medium gable roof. Horizontal clapboard exterior, vertical boards, narrow and wide battens alternating, gable ends. Vertical board slide opening door, offset on south gable end, one vehicle capacity. Rectilinear arrangement, three pine trees, centered each gable end; twounit angular center tree flanked by two simple trees, each with base. Each tree cut from two boards, joined, each interrupts narrow batten. No apparent alteration. 
Mt. Adams Ranger District

R6-03-03-DE13

Willard, Building \#2611: Rectangular, $1 \frac{1}{2}$-story wood frame, poured concrete foundation, high gable roof, center porch gable, east facade, supported by two heavy squared-timber posts, with short, narrow flush brackets. Horizontal clapboard exterior, vertical boards, angular cut, battens gable ends and porch pediment. Six-over-six double-hung sash windows, singly and in combinations with mullions. Concrete porch platform, three side steps, center east facade. Three pine tree cut outs, centered, porch gable pediment; two-unit angular center tree flanked by two simple trees, each with narrow rectangular base, each cut from single board. Textured metal roof material.

R6-03-03-DE14

Willard, Garage/Shed: Rectangular, wood frame, two bay, dirt floor, wood-shingled medium gable roof. Horizontal clapboard exterior, vertical boards, angular cut, narrow and wide battens alternating, on gable ends. Vertical board slide opening door, off-set on south gable end, one vehicle capacity. Rectilinear arrangement, three pine trees, centered, twounit angular center tree flanked by two simple trees, each with narrow rectangular base. Each tree cut from two boards, joined, each interrupts narrow batten. No apparent alteration.

R6-03-03-DE-RI Peterson Prairie Information Station: Small, rectangular, log registry booth, medium gable roof, long split-shakes. Entire structure is constructed of peeled logs, graduated diameters, ends chamfered and square sawn. North elevation, rear, entirely enclosed by vertical log wall, east and west gable ends, semi-enclosed, off-center entry on each, flanked by vertical logs of graduated heights, not extending to lintel. South elevation partially enclosed by vertical log railing, ca. three feet in height. Gable ends enclosed only by triangular truss members, two diagonal pole brackets, 
Mt. Adams Ranger District

R6-03-03-DE-RI cupped to fit. Information board is affixed to north wall, secured by vertical log base and horizontal log crossmember. No visible alteration. In excellent condition. 


\section{GIFFORD PINCHOT NATIONAL FOREST}

Randle Ranger District

R6-03-05-DE1

Randle Ranger Station, Ranger's Residence

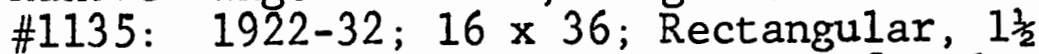
story wood-frame, poured concrete foundation, medium gable roof, bracketed verges, large gabled dormer, south slope, portion of south slope extends to cover wood porch, off-center main entry, single story shed-roofed bay, center west gable end, shed-roofed enclosed end-porch extends width of east gable end, ground story level. Single brick chimney off-set on south slope of roof. Horizontal shiplap exterior, end boards. Six-over-one double-hung sash windows in combinations with mullions. Porch has low simple railing, south side only. No decoration. No obvious structural or material alterations to exterior, except composition shingles on roof.

Root House \#1950: 1935; $120 \mathrm{sq}$. ft.; Rectangular, wood-frame, wood-shingled medium gable roof. Horizontal clapboard exterior, bracketed verges. Center door and window opening south elevation.

R6-03-05-DE2

North Fork Guard Station \#1142: 1937; $16 \times 25$; Rectangular, 1 story wood frame, poured concrete foundation, wood shingled high gable roof, off-set gable on south elevation main entry, off-set, recessed in south gable supported by one heavy squared-timber post, single heavy, short outward curving bracket, affixed, stepped gable on east gable end forms side entry. Single coursed rubble interior chimney straddles main ridgeline, center. Horizontal clapboard exterior, vertical boards corner notched, all gable ends. Functional vertical board shutters cover windows, single simple pine tree cut out, above center on each. Single large slender pine tree cut out, slightly above center, on east, west, and south gable ends; each cut from single board. No obvious alterations, structural or material, to exterior. 
Randle Ranger District

R6-03-05-DE3

North Fork Guard Station, Garage \#1551: 1938; 16 × 18; Rectangular, wood frame, two bag, poured concrete foundation, woodshingled medium gable roof. Horizontal clapboard exterior, vertical boards, corner notched, on gable ends. Six-light sash windows. Single leaf vertical board door, two-leaf vertical board door, hinged opening on south gable end. Single large slender pine tree cut from two boards above center on each gable end. No obvious alteration.

R6-03-05-DE4

Randle Work Center, Gas and Oil House \#2550: 1936; $10 \times 10$; Square, wood frame, poured concrete foundation medium gable roof. $1 \times 12$ horizontal clapboard exterior, vertical boards, corner notched, gable ends. Anterior (south) wall recessed, extended gable covers pumps. Sixlight sash windows. Slide opening, vertical plank door, center south facade, two large complex pine tree cut out, above center. Single large complex tree centered on each gable end, cut from two boards. Textured metal roof material.

R6-03-05-DE5

Randle Work Center, Fire Control Warehouse \#2250: 1935; 28 x 48; Rectangular, 2 story, wood frame concrete piers, medium gable roof, verges bracketed. Narrow, rounded horizontal shiplap exterior, end boards vertical boards to water table level. Six-light sash windows. Two leaf vertical board slide opening doors, center, west gable end, single leaf door set into right door. Shed roof porch, raised plank platform off-set on south elevation, covers slide-opening loading door. No decoration. Textured metal roof material.

R6-03-05-DE6

Ranger's Residence Garage \#1550: 1935; $20 \times 22$; Rectangular, wood frame, poured concrete foundation, wood-shingled medium gable roof, bracketed verges. Horizontal shiplap exterior, end boards, narrow vertical shiplap to water table level. Two large slide opening doors, south gable 
Randle Ranger District

R6-03-05-DE6

R6-03-05-DE7

R6-03-05-DE8 end, diagonal shiplap reinforced. No decoration.

Randle Work Center, Shop Building \#2150: $1936 ; 52 \times 82$; Rectangular, $1 \frac{1}{2}$ story wood frame, poured concrete foundation, medium gable roof, center gable two offset gables, north (main) facade, two triangular dormers, each north and south roof slopes. Single brick interior chimney, off-set south roof slope. Horizontal clapboard exterior, vertical boards corner notches, all gable ends. Seven bays in length, seven vertical lift vehicle doors on north facade, large center door four panels in width, each panel has ten-light window, on west gable end. Mullion windows with four and eight divisions, six and nine lights on east, west and south elevations. Single large complex pine tree cut out, edges serrated, with base, on each gable end on north facade. Certain of vehicular doors on north facade are modern replacements. Textured metal roof material.

Randle Work Center, Warehouse \#2251:

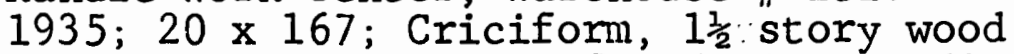
frame, poured concrete foundation, medium gable roof with intersecting center cross gable, verges bracketed, anterior (east) wall of center gable recessed to form porch covering concrete loading dock, supported by four $10 \times 10$ posts. Horizontal shiplap exterior, end boards. Sixlight sashes in combinations with mullions. Eight bays, excluding center gable, on east elevation; four outer bays are enclosed by vertical boards with diagonal battens to resemble slide opening doors of four inner bays. Center gable has similar slide-opening door, at center, accessed by loading dock, second vertical board door, diagonal battens centered, upper level, east gable end. No decoration. Textured metal roof material; one of vertical board doors on east elevation replaced by plywood enclosure with 
Randle Ranger District

R6-03-05-DE8

laminated flush door set in. $1 \frac{1}{2}$ story wood-shingled addition to west gable end, gabled roof with hipped, wood-frame cupola astride ridgeline.

R6-03-05-DE9

Randle Work Center, Old Office \#2050:

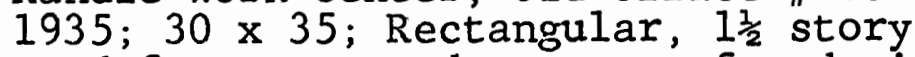
wood frame, poured concrete foundation, high gable floor, major off-set gable on north (main) facade. Main entry, offset and recessed in north off-set gable, porch supported by one $10 \times 10$ post; open flagstone platform, three straight stone steps. Horizontal clapboard exterior, vertical boards, corner notched, on ail gable ends. Six-over-six double-hung sash windows, single and in combinations with mullions. No decoration. Textured metal roof material. Original flagpole and base, to north and east of office on lawn. Bronze plaque mounted on native basalt base set into lawn; Inscription: "Planted In Memory of - Robert Fechner 1933-1939 - By Company 2919 CCC Camp Lower Cispus F34 - Randle, Washington."

R6-03-05-DE10

Randle Work Center, Barn \#2450: 1935; $50 \times 52$; Rectangular, wood frame, split shake gambrel roof, bellcast eaves, hipped roof extensions on north, south and west elevations, original design and fabric. Hipped roof wood frame cupola centered on ridgeline, formerly had brass mule weather-vane. Horizontal shiplap exterior, end boards; four panels, horizontal shiplap, outlined by 1 ' 4 , off-set on east and west gable ends are slide-opening doors; north extension is enclosed, with door openings at each end-e.g. dog-trot; south extension is enclosed on gable ends but open, five bays, on south elevation to access stalls. No decoration. No obvious alterations. 
GIFFORD PINCHOT NATIONAL FOREST

Wind River Ranger District

R6-03-08-DE1

Wind River Training Center \#2815 (HodgsonLindberg Training Center): 1936; 38 x 40; Rectangular, 2 story wood frame, poured concrete foundation, wood shingled high hipped roof, bellcast eaves on south slope extend to form porch roof length of main facade, high center gables, north and south slopes of roof, two hipped dormers on north (rear) siope. Porch is supported by four groups of three $10 \times 10$ posts, outer members employ short, flush curving bracket; two wide straight stone steps ascent to open flagstone platform, base veneered with random rubble. Massive exterior end chimney, coursed, squaredrubble, centered, north elevation. Horizontal clapboard to first story level, vertical boards, angular cut, . wide battens, second story level and on gable ends. Six-over-nine double-hung sash windows, singly and in combinations with mullions, second story level, gable ends and dormers. Ground story windows are flanked by vertical board decorative shutters, each exhibiting a simple pine tree cut out, upper center. Main entry off-set on south elevation, vertical board door, nine light narrow panel; two two-leaf french doors located on north elevation, off-set. Three large elegant pine trees, rectilinear arrangement, located below peak of roof on south gable end. No obvious exterior alteration.

$R 6-03-08-D E 2$

Wind River Training Center, Bunkhouse

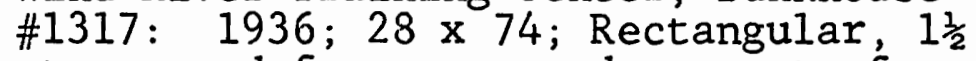
story wood frame, poured concrete foundation, basement, random rubble veneer, wood shingled hipped roof, projecting center porch gable, supported by two pair of 10 $x 10$ posts, short, flush curving side brackets, affixed. Four wide straight stone steps ascent to open flagstone platform, random rubble masonry base. Random rubble interior chimney, stonecap, offset on south slope of roof. Horizontal clapboard exterior, vertical boards, angu- 
Wind River Ranger District

R6-03-08-DE2 lar cut, wide battens, all gable ends. Six-over-six double-hung sash windows, flanked by decorative shutters, each exhibiting a single simple pine tree cut out, on ground story; upper level, muliion windows of three divisions, each with eight vertical lights. Main entry, center, south facade; side entries, centered, east and west gable ends, decorated architraves. A single large pine tree cut out centered on porch gable pediment. No obvious exterior alteration.

R6-03-08-DE3

R6-03-08-DE4

Pacific Northwest Experiment Station Office \#1319 (Recreation Hall): 1936;

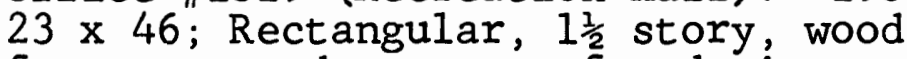
frame, poured concrete foundation, wood shingled high gable roof, portions of east and west roof slopes extend, bellcast, to form front and rear porches. Front porch (east elevation) off-set, supported by four squared-timber posts, enclosed by low vertical board railing, which exhibits slender pine trees, cut out and interspaced; rear porch, enclosed, horizontal shiplap exterior; two hipped dormers, west slope of roof. Horizontal shiplap exterior, end boards. Six-oversix double-hung sash windows, singly and in combinations with mullions, flanked by decorative board shutters, each having a small, slender pine tree cut out, centered. No obvious additions or alterations to exterior.

Hemlock Ranger Station, Ranger's Residence \#1045: 1938; 35 x 31; Rectangular, $1 \frac{1}{2}$ story, wood frame, poured concrete foundation, high gable roof, off-set gable, east (main) facade; shed-roofed bay center, south gable end; gabled bay, off-set, north gable end, shed roof center entry, porch supported by two large squared-timber posts, short flush curving brackets. Horizontal clapboard exterior, vertical board, angular cut, battens on all gable ends. Six-over-six double-hung sash windows, singly and in combinations with mullions. Single capped brick interior chimney, off-set 
Wind River Ranger District

R6-03-08-DE4 on east slope of roof. No decoration. Textured metal roof material.

R6-03-08-DE5 Hemlock Ranger's Residence Garage \#1515: 1934; 16 x 18; Rectangular, wood frame, poured concrete foundation and floor, wood shingled high gable roof, verges bracketed. Horizontal shiplap exterior, end boards. Eight horizontal light sash windows. Single large vertical lift door, west gable end. No decoration.

R6-03-08-DE6

Hemlock Residence \#1046: 1933; 35 x 28; Rectangular, $1 \frac{1}{2}$ story wood frame, high poured concrete foundation high gable roof, bracketed verges, center porch gable, east (main) facade, large shed roofed dormer, west elevation. Stretcher bond brick exterior end chimney capped, off-set south elevation, brick interior chimney, capped, off-set east roof slope. Horizontal shiplap exterior, end boards; water table; mullion window, large single pane, flanked by four vertical side lights, surmounted by four transom lights; six-over-one double-hung sash windows. No decoration. Textured metal roof material. 
MALHEUR NATIONAL FOREST

John Day Compound

R6-04-SO-DE1

Supervisor's House \#1001: 1938; 26' $\mathrm{x}$ $43^{\circ}$; T-shaped, $1 \frac{1}{2}$ story, wood-frame, poured concrete foundation, basement, wood-shingled medium gable roof with hiproofed enclosed porch in rear. Squaredrubble, coursed stone chimneys off-set straddiing ridgeline and on rear slope of roof. Wall shake exterior, vertical board and batten on all gable ends. Eight-over-eight and six-over-six doublehung sashes, one twenty-light wood casement window. No decoration. No significant exterior alteration apparent.

R6-04-SO-DE1A

R6-04-SO-DE2

Detached rectangular, single vehicle wood-frame garage. Wood-shingled inedium gable roof, wall shake exterior with vertical board and battens on gable ends. No decoration.

Assistant Supervisor's House \#1002:

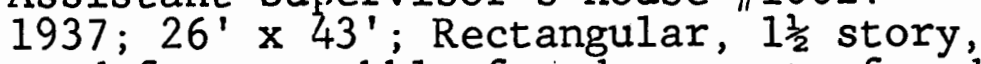
wood-frame, rubble-faced concrete foundation, wood-shingled medium gable roof, hipped roofed dormer on rear slope.

Horizontal clapboard exterior, vertical board and batten on gable ends. Coursedrubble chimney off set on rear roof slope. Six-over-six double-hung sash windows singly and in combinations with mullions. Enclosed gable-roofed porch and rear entrance on south elevation. No decoration. No significant exterior alteration apparent.

R6-04-SO-DE2A Detached two vehicle wood-frame garage, rectangular, wood-shingled medium gable roof. Horizontal clapboard exterior, vertical boards, with angular cut, battens every other board on gable ends. No decoration.

R6-04-SO-DE3

Caretaker's House \#1003: 1941; 25' $\mathrm{x}$ $36^{\prime}$; Rectangular, $1 \frac{1}{2}$ story, wood-frame, poured concrete foundation, wood-shingled medium gable roof, coursed-rubble stone chimney above offset front gable. Hori- 
John Day Compound

R6-04-SO-DE3

zontal clapboard exterior, vertical boards, with angular cut, battens every other board on all gable ends. Six-oversix double-hung sash windows singly and in combinations with mullions. A single compound pine tree logo cut from two boards immediately below peak of roof on south elevation. No obvious exterior alteration.

R6-04-SO-DE4

R6-04-SO-DE 5

R6-04-SO-DE5A

Timber Sale House \#1004: 1946; 20' $\mathrm{x}$ 30'; Rectangular, 1 story wood-frame, poured concrete foundation, wood-shingled medium gable roof, brick chimney, center, front slope of roof. Horizontal clapboard exterior, wood corner trim, vertical board and batten on gable ends. Six-oversix double-hung sash windows, singly and in combinations with mullions. No decoration. Replacement of some sash windows with aluminum casements. Design and materials compatible with Depression-era structures, albeit built 1946 .

Ranger's House \#1006: 1936; 34' x 34'; Square, $1 \frac{1}{2}$ story, wood-frame, poured concrete foundation, wood-shingled medium gable roof; offset gable north facade; bellcast eaves form porch roof for open verandah running width of north facade supported by squared timbers with curving inset brackets; large hipped-roof dormer on south slope of roof. Coursed, squaredrubble stone chimney, exterior on east elevation, coursed squared-rubble chimney offset on south roof. Horizontal clapboard exterior, vertical boards, angular cut, with battens every other board on all gable ends. Six-over-six double-hung sash windows, singly and in combinations with mullions. Decorative shutters with simple pine tree cut outs flank each window on main level. Possible addition to south elevation with aluminum casement windows.

Detached two vehicle wood-frame garage, rectangular, wood-shingled medium gable roof: Horizontal clapboard exterior, vertical boards, angular cut, with battens 
John Day Compound

R6-04-SO-DE5A

every other board on gable ends. Single compound pine tree logo centered below peak of roof on gable ends.

R6-04-SO-DE6.

WCF Shop \#2100: 1936; 45' x 80'; Rectangular, 2-story, wood-framed, woodshingled hipped gable roof with two offset intersecting gables, two gable-roofed dormers each on front and rear main roof slopes. Horizontal clapboard exterior, vertical boards on offset gable ends. Combinations of nine-light sash windows with mullions. Four large slide-opening doors with windows, main facade. Single well-defined pine tree cut out centered on each gable end. No obvious exterior alteration.

R6-04-SO-DE7

Fire Warehouse \#2300: 1938; 50' $\times 80^{\prime}$;

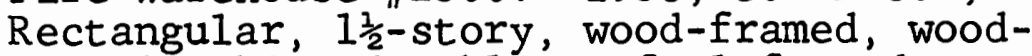
shingled hipped gable roof, loft and below-ground storage. Horizontal clapboard exterior. Center gable porch, vertical board pediment, on main (east) facade. Exterior stairway with railing to loft entrance, north elevation. Below ground-level entrance, south elevation. Single well-defined pine tree logo centered on east porch gable pediment. Shedroofed lean-to storage addition to west (rear) elevation.

R6-04-SO-DE8

District Warehouse 少2300: 1938; $50^{\prime} \mathrm{x}$

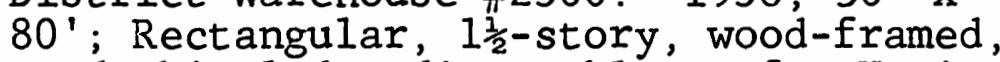
wood-shingled medium gable roof. Horizontal clapboard exterior, vertical boards, angular cut, with battens every other board on gable ends. Six bays in length, two bays deep, vertical board slideopening doors, interspaced with squaredtimber posts having curving inset brackets. Single well-defined pine tree logo centered below peak of roof on each gable end. Large sliding door on north (rear) elevation recently replaced with hingeopening two-leaf doors. 
John Day Compound

R6-04-SO-DE9

Open Storage \#2301: 1936; $50^{\prime} \times 0^{\prime}$;

Rectangular, 1-story, wood-framed, poured concrete foundation, wood-shingled medium gable roof, open on east (main) facade, six bays in length, interspaced with squared-timber posts having curving inset brackets. Horizontal clapboard exterior, vertical board, angular cut, battens every other board on gable ends. Single, well-defined pine tree logo, slightiy above center on each gable end. No obvious alteration.

R6-04-S0-DE10

Barn \#2400: 1937; 25' × 37'; Rectangular, poured concrete foundation, wood-frame, wood-shingled medium gable roof for two horses. Horizontal clapboard exterior, vertical boards on gable ends. Hay loft. Six-light horizontal single sash windows. Vertical board slide-opening doors on south and north gable ends. No decoration. No obvious exterior structural alteration. 
MALHEUR NATIONAL FOREST

Prairie City Ranger District

Trout Farm Cormunity Shelter: Rectangular, three bay, post and beam construction using large diameter logs and unpeeled poles. Split long shake medium gable roof. Six vertical posts, four equidistant on east elevation, straight unpeeled brackets, ax-cut notches in uprights, side and corner. Gable ends and west elevation open. Posts have stone footings. Dirt floor. Single peeled pole base railing on east, west and north sides. Posts, cross-members, lintels, ridgepoles, rafters and purlins of somewhat dissimilar diameters. Two brackets missing, some defacement and evidence of vandalism. Question as to date of construction. Principles of rustic design evident in scale, proportion and use of natural and native materials. Imperfect logs and poles used, less-skilled construction with cruder finish than most examples. 
MALHEUR NATIONAL FOREST

Bear Valley Ranger. District

Wickiup Campground: Eight campsites in core area, have considerable integrity of design and construction; widely separated and screened by native vegetation, spacious with adequate space for tents. Massive convertible campstoves, cooking grill approximately three feet in height, of informal masonry using large boulders of red lava-rock, natural finish, minimal cut to fit. Amphitheater has three large half-log benches set into slope, six feet in length, widely spaced at intervals on hillside. Sinall stone steps access. A masonry wall, informally textured red lava rock, curves slightly at base of slope, defining area. Part of wall, broken and missing. 
MT. BAKER-SNOQUALMIE NATIONAL FOREST

Baker River Ranger District

R6-05-01-DE1 Koma Kulshan Guard Station, Residence

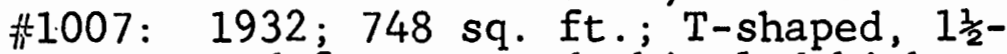
story, wood-frame, wood-shingled high gable roof with center gable, real elevation, small center gable porch, partial$1 y$ enclosed, north (main) facade. Wood shingle exterior, vertical boards on porch gable pediment. Center gable porch supported by two large, tapering peeled poles with notched pole crossmember. Three small, intricate pine tree cut outs in triangular pattern centered on single center board of porch pediment. No obvious exterior alteration.

R6-05-01-DE2 Koma Kulshan Guard Station, FR\&T Building \#2200: 1932; $810 \mathrm{sq}$. ft.; Rectangular, $1 \frac{1}{2}$-story wood-frame, concrete pier foundation; wood-shingled high gable roof, extending to form porch, length of main (S.W.) facade, supported by four $4 \times 4$ posts. Horizontal shiplap exterior, end boards. Plank porch extends length of main facade. No decoration. No apparent exterior alteration.

R6-05-01-DE3 Koma Kulshan Guard Station, Equipment Storage \#2240: 1932; 2240 sq. ft.;

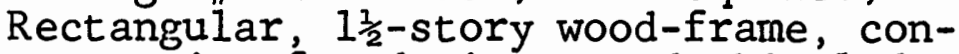
crete pier foundation, wood-shingled high gable roof. Horizontal shiplap exterior. Eight bays in length, eight large slide-opening doors on main facade, northeast elevation. No decoration. No obvious exterior alteration. 
MT. BAKER-SNOQUALMIE NATIONAL FOREST

Darrington Ranger District

R6-05-02-DE1

Darrington Ranger Station 01d Bunkhouse

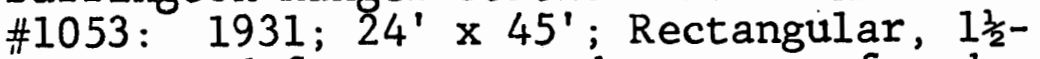
story wood-frame, poured concrete foundation, wood-shingled medium gable roof, with gabled porch supported by pairs of $8 \times 8$ posts and semi-enclosed by simple railing offset on south gable end, enclosed end-porch, low hip roof, 1-story width of north gable end, smali shedroofed lean-to abuts center of end porch. Two brick interior chimneys straddle ridgeline. Wood shingle exterior in alternate rows with staggered butts. One-over-one double-hung sash windows in pairs with mullions; eight-horizontallight sashes, on north enclosed endporch. No decoration. Shed-roofed leanto may be a later addition.

R6-05-02-DE2

Darrington Ranger Station Dwelling \#1228:

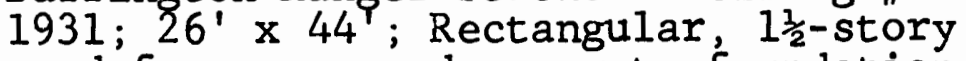
wood-frame, poured concrete foundation, basement, wood-shingled medium gable roof; south: (main) facade recessed width of gable end on ground level to form porch, supported by two large square posts at corners, four $4 \times 4$ posts interspaced, raised open platform, plant surface; shed-roofed enclosed end-porch offset on north gable end. Single stretcherbond brick exterior chimney, off-center on east elevation. Wood-shingle exterior in alternate rows with staggered butts. One-over-one double-hung sash windows, singly and in combinations with mullions. Mullion window with two one-over-one sashes centered on south gable end has decorated projecting lugsill bearing a small simple railing, with turned corner posts. Storm doors and windows added. No significant exterior alteration apparent.

R6-05-02-DE3

Darrington Ranger Station, Dwelling \#1232:

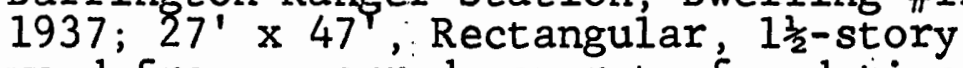
wood-frame, pouxed concrete foundation, basement, wood-shingled high gable roof, east (front) wa11 recessed one-half length 
Darrington Ranger District

R6-05-02-DE3

$\mathrm{R} 6-05-02-\mathrm{DE} 4$

of structure to form porch, supported by heavy squared-timber posts having large curving brackets affixed; rear entrance, center north facade, recessed in corner of roof extension. Two hipped dormers on west slope of roof; two interior end chimneys, coursed, squared-rubble. Horizontal clapboard exterior, ground floor, vertical boards, battens every other board on gable ends and on upper level west elevation. Mullion windows of three eight-over-eight double-hung sashes; ninelight sashes singly and in combinations. No decoration; storm doors and windows added, no significant structural alterations to exterior.

Darrington Ranger Station, Bunkhouse \#1316: 1935; 100' × 30'; Rectangular, $1 \frac{1}{2}$-story wood-frame, poured concrete foundation, wood-shingled medium gable roof; projecting gable offset on east (main) facade forms porch, supported by two stone columns of ashlar-like coursed rubble masonry; two gabled hoods supported by $4 \times 4$ brackets offset on west elevation above entries. Horizontal clapboard exterior, vertical boards, battens every other board on gable ends, vertical boards only on porch gable pediment. Sixover-six double-hung sashes singly and in combinations with mullions. No decoration. No obvious structural alterations to exterior.

R6-05-02-DE5 Darrington Ranger Station Road Crew Shop \#2190: 1933; 58' x 100'; U-shaped, 2story wood-frame, poured concrete foundation, wood-shingled medium gable roof with projecting offset gables at either end, three large gabled dormers, south slope, main gable; single brick interior chimney offset on south slope. Horizontal clapboard exterior, vertical boards, battens every other board on all gable ends and on dormer gable pediments. Nine-light sash windows, singly and in combinations with mullions; two nine-light sash windows in each dormer. Large vertical- 
Darrington Ranger District

R6-05-02-DE5

R6-05-02-DE6

R6-05-02-DE7

Darrington Ranger Station Blacksmith Shop

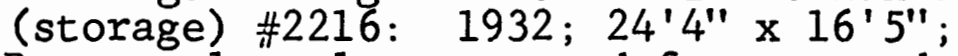
Rectangular, 1-story wood-frame, woodshingled medium gable roof. Horizontal clapboard exterior, vertical boards, battens every two boards on gable ends. Nine-light sash windows. Two-leaf vertical board doors with nine-light windows centered, west gable end. Two welldefined pine tree cut outs, equidistant from center, on west gable end only. No obvious alteration to exterior.

R6-05-02-DE8

Darrington Ranger Station, FR\&T Building \#2275: 1932; 24'5" x 36'6"'; Rectangular, 1-story wood-frame, wood-shingled medium gable roof. Wood shingle exterior, in alternate rows with staggered butts. Sixhorizontal-light sash windows. Large slide-opening door, offset east gable end. Entry not covered. No decoration; no apparent exterior alteration. 
Darrington Ranger District

R6-05-02-DE9

R6-05-02-DE10

Darrington Ranger Station Barn \#2417:

1916 ; $30^{\prime} \times 67^{\circ}$; Rectangular, wood-frame, wood-shingled bellcast gambrel roof. Horizontal board exterior, end boards . Nine-light sash windows. Large slideopening door, reinforced diagonal board, center south gable end; hay door center south gable end at left level; two-leaf vertical board door, center north gable end. No decoration; some exterior material alterations.

R6-05-02-DE-RI Clear Creek Community Kitchen: 1933-35;

Darrington Ranger Station Gas House \#2215: 1933; 16'4" x 22' 6"'; Rectangular, woodframe, poured concrete foundation, woodshingled medium gable roof; east anterior wal1 recessed to form umbrage, entry flanked by two heavy squared-timber posts with large curving inset brackets; raised timber and plank loading dick abuts west gable end. Vertical board and batten exterior, horizontal clapboard on gable ends. Mullion windows having two four-light sashes are flanked by proportionate vertical board decorative shutters with simple pine tree cut outs centered. Threevertical-light sashes flank the entry. No obvious exterior alteration. Formerly an octagonal $\mathrm{log}$ and pole structure. All that remains are the octagonal concrete platform and the central chimney which exhibits a random-coursed river cobble masonry; two end stoves remain also, although the stove tops and doors are missing.

R6-05-02-DE-R2 Buck Creek Shelter: 1933-35; 20' x 15'; Substantial adirondack-type shelter of peeled log construction. Rear and both gable ends are partially enclosed by solid railing, large uprights are spaced to support five roof joists; the most anterior cross-member rests on massive log posts, the most posterior rests on the rear railing. The roof is of split shakes. The east elevation is open. No obvious structural alteration, some roof- 
Darrington Ranger District

R6-05-02-DE-R2 shakes missing. In very good condition.

R6-05-02-DE-R3 French Creek Community Kitchen: 1933-35; $16^{\prime} \times 22^{\prime}$; Rectangular, peeled 1 og and pole construction, split-shake medium hip roof; random-coursed river cobble masonry chimney on east elevation center fireplace, two side stoves. Roof is supported by ten large-diameter logs, equidistant around perimeter of concrete platform. Two half-log picnic tables with randomcoursed river-cobble bases remain, each table has two half-log benches with similar river-cobble bases. No obvious structural alteration; roof materials missing or deteriorated, stone chimney-cap broken. 
MT. BAKER-SNOQUALMIE NATIONAL FORZST

Glacier Ranger District

R6-05-03-DE1

Glacier Ranger Station Office \#2021:

1938; Criciform, 1-story wood-frame, woodshingled high gable roof, gabled hips on longitudinal cross gables. Anterior wall of main center gable recessed to form porch, supported by four masonry posts of angular basalt, having an ashlar-like appearance; the porch platform is raised, open and surfaced with flagstone. Horizontal clapboard exterior, with basalt masonry walls on the projecting center gable; vertical boards with small triangular corner cuts on center gable end. Massive basalt masonry exterior chimney, ashlar-like, rises on east wall of north projecting center gable. The window surrounds of the main center gable are stone -ramed with projection stone slipsills; arched window wells with radiating voussoirs. Center, two-leaf French doors; six-over-six double-hung sash windows. Extensions of gabled-hip roof on east and west gable ends cover enclosed projecting restroom facilities. Squared-tiunber cross member beneath center gable end exhibits carved scroll design and "U.S.F.S." initials flanking carved "OFFICE" sign. Rectilinear arrangement of two wellshaped pine tree cut outs flanking a third, larger tree, centered on north gable end. Each tree is cut from a single board. No apparent alterations.

R6-05-03-DE2

Glacier Ranger Station, Residence \#1091:

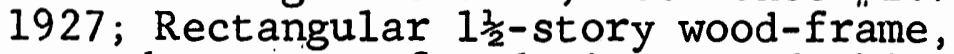
poured concrete foundation, wood-shingled high gable roof with offset gable on south (main) facade; small, semi-enclosed gable roofed porch offset on north elevation. Stretcher-bond brick exterior chimney, corbeled cap on east gable end. Wallshake exterior. Six-over-six double-hung sash windows, twelve-light single sash flanked by eight-light sashes with mullions. Main entrance off-center in offset gable, semi-circular structural opening, vaulted recess, single buttress 
Glacier Ranger District

R6-05-03-DE2

R6-05-03-DE-II

R6-05-03-DE-R1

R6-05-03-DE-R2 flanking. Formerly Ranger District Office. No decoration; no significant alteration to exterior.

Log Section Interpretive Site: 1939; 13' $x 20^{\prime}$; Coursed-rubble platform, flagstone surface, two stone steps; log section mounted on stone base having vertical rock sections implaced on long axis. Now covered with semi-circular steelframe, wood shingles.

Silver Fir Community Kitchen: 1936; Octagonal, peeled log and pole construction; wood-shingled roof with hewn log finial at peak. Eight large logs of similar diameter form upright supports each having two round pole brackets, two horizontal poles form railing interspersing the posts each pair of poles having one slender upright centered. Large coursedrubble masonry chimney partially encloses one side, center open hearth fireplace, two side stoves. Single entrance flanked by short sections of horizontal pole railing having intermediate diameter short posts. Flagstone floor. 1936 photograph by A. D. Taylor shows horizontal pole railings separated by seven slender uprights; logs and poles unpeeled. No other apparent alterations. (Taylor comments that roof would be more pleasing if thicker shingles or shakes had been used; shelter wall located and excellently designed.)

Douglas Fir Community Kitchen: 1937; 24' $x$ 36'; Rectangular; peeled $10 g$ and pole construction, wood-shingled medium-hipped roof. Ten large-diameter logs forn upright supports, railing of two horizontal poles with a diagonal cross-member interspersed. Rear elevation partially enclosed by massive exterior chimney of coursed-rubble masonry, informal, sides space open. Center open hearth fireplace, two side stoves. Concrete platform. Roof shingles replaced, 1976. Five straight stone stairs lead down from parking area at rear of structure. 


\section{MT. BAKER-SNOQUALMIE NATIONAL FOREST}

Monte Cristo Ranger District

R6-05-04-DE1 Monte Cristo Ranger Station Office \#2031:

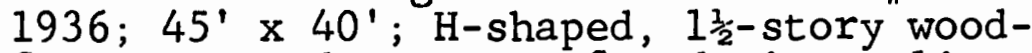
frame, poured concrete foundation splitshake high hipped roof, offset cross gables, center gable with extending gabled porch north (rear) elevation; two hipped dormers on both south and north roof slopes. South (front) wall recessed between offset gables to form porch, supported by two squared-timber posts with smal1, short curving brackets affixed. Horizontal clapboard exterior, vertical boards, angular cut, with molded battens on gable ends. Small, coursed-rubble interior chimney straddles main ridgeline; center. Eight-over-eight double-hung sashes singly, six-over-six double-hung sashes in combination with mullions. Dormers exhibit nine-light single sash windows. Al1 windows on main level flanked by vertical three-board decorative shutters, the center board having a simple pine tree cut out. A single graceful, well-executed pine tree cut out from a single board is centered on each offset gable end. The front door handle is hand-forged, backed by a forged plate of pine tree design; the lock is backed by a small forged plate having the shape of the U. S. Department of Agriculture shield. No apparent exterior alterations, excellent condition.

R6-05-04-DE2

Monte Cristo Ranger Station, Ranger's Dwelling \#1136: 1936; 45' x 40'; Tshaped, $1 \frac{1}{2}-$ story wood-frame, poured concrete foundation, split-shake high gable roof with intersecting cross-gable, stepped on north (rear) elevation, forming projecting bays. Single hipped dormer, center main gable, north slope; single coursed, squared-rubble interior chimney, offset, north slope. Hipped porch roof extends from west gable end, supported by pairs of large squared-timber posts, short, slender curing brackets affixed. Horizontal clapboard exterior, vertical 
Monte Cristo Ranger District

R6-05-04-DE2

boards, angular cut, molded battens on all gable ends; ashlar-iike coursed rubble veneer to eave line on projecting north bay, similar masonry finish to window level on south bay. Mullion windows in south bay are six-over-nine sashes across, fourover-six sashes on sides. Rear bay exhibits a mullioned window having three sixover-six sashes; treatment repeated on west elevation. Front door exhibits a hand-forged handle and latch, backed with forged pine-tree shaped plate; lock is backed with small shield shaped plate; centered, a hand-forged door-knocker in form of tree branch with two short side branches and a beautifully wrought pine cone knocker. A hand-forged wrought-iron lanter serves as porch light beside north entrance. No visible exterior alteration, excellent condition.

R6-05-04-DE3

Ranger's Residence Garage \#1546: 1936; Rectangular wood-frame, poured concrete foundation, split-shake high gable roof; attached to residence by means of a below ground surface snow tunnel having coursed, squared-rubble masonry walls and a splitshake high gable roof. Horizontal clapboard exterior, vertical boards, angular cut, molded battens. Six-light horizontal sash windows; two vertical board doors, north gable end. Two vehicle capacity. Single well-executed pine tree cut out from single board above center on north and south gable ends. No apparent exterior alteration.

R6-05-04-DE4

Monte Cristo Ranger Station Timber Office

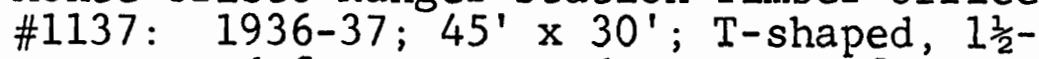
story wood-frame, poured concrete foundation, split-shake high gable roof with projecting center gable on south elevation, gabled entrance abuts at right angle to recessed open porch and main entry on south facade; entrance supported by $4 \times 4$ posts, porch supported by heavy squaredtimber posts having short, slender curving brackets affixed; small projecting gableroofed porch, entry offset on west gable end, open, supported by squared-timber 
Monte Cristo Ranger District

R6-05-04-DE4

posts with short curving brackets affixed. Single hipped dormer on north slope. Large ashlar-like coursed-rubble masonry exterior end chimney on east gable end, similar masonry interior chimney, center, south slope, smaller similar interior chimney straddles ridgeline of projecting center gable. Horizontal clapboard exterior, vertical boards, angular cut, molded battens on all gable ends. Mullion window with three eight-vertical-light sashes, south facade; eight-over-eight double-hung sashes singly and in combinations with mullions. Front door exhibits hand-forged handle and latch, backed by forged pine-tree shaped plate; lock is backed by sinall shield shaped plate. Single, well-executed pine tree design cut out from single board above center on center gable end, south facade. No apparent exterior alterations, excellent condition.

R6-05-04-DE5

Monte Cristo Ranger Station Warehouse \#2290: 1935-38; 90' x 60'; Rectangular, 2-story wood-frame, poured concrete foundation, high gable roof, center gable, south (main) facade; offset slightly projecting gable, west gable end; stepped center gable with projecting gable porch above concrete loading dock, supported by two large squared-timber posts with short, shallow flush brackets affixed on north (rear) elevation. Single coursed-rubble interior chimney, offset on north slope. Horizontal clapboard exterior, vertical boards, angular cut, molded battens on all gable ends. Mullion windows of four twelve-light sashes surmounted by center sash of twenty lights flanked by fifteenlight sashes. Gable ends, four bays in width, east gable end has four large vertical-lift doors, single large verticallift door center offset gable on west gable end. No decoration. Original roof material replaced with corrugated sheet metal. 
Monte Cristo Ranger District

$\mathrm{R} 6-05-04-\mathrm{DE}_{6}$

North Fork Guard Station: 1930's?; $30^{\prime} \times 25^{\prime}$; Rectangular, 1-story woodframe, wood-shingled medium gable roof, small center gable on south facade forms porch roof, supported by two round peeled poles. Wood shingle exterior. One-overone double-hung sash windows. No decoration. No obvious alteration to exterior. Small detached shed-roofed woodshed, enclosed on three sides by vertical boards, peeled pole frame. 
MT. BAKER-SNOQUALMIE NATIONAL FOREST

North Bend Ranger District.

$\mathrm{R} 6-05-05-\mathrm{DE} 1$

North Bend Ranger Station Fire Control Office 非032: 1936; 28'x55'6"; T-shaped, 1-story wood-frame, poured concrete foundation, split-shake stepped medium gable roof with gabled hip on north, center cross gable, projecting on east facade. Single coursed, squared-rubble masonry interior chimney center, main ridgeline. Horizontal clapboard exterior, vertical boards, battens every other board on all gable ends and gablets. Six-over-six double-hung sashes, singly and in combinations with mullions. Main entrance, offcenter on east facade, porch formed by extension of gabled hip, supported by large squared-timber post, slender, slightly curving brackets, affixed; porch platform of coursed-rubble masonry, flagstone surface, open, two straight steps. Single, well-defined pine tree cutout centered on gablet above main entry. Some windows replaced with aluminum casements.

R6-05-05-DE2

North Bend Ranger Station Equipment Repair Shop 非130: 1936; T-shaped, wood-frame, poured concrete foundation, wood-shingled gabled hip roof, projecting center gable on north (rear) elevation, large gabled dormer, unlighted, center south slope of roof. Horizontal clapboard exterior, end boards, vertical boards, battens every board on west gablet and north-facing center gable end. Nine-light sashes, singly and in combinations of eight with muliions and four surmounted by four sixlight sashes with mullions. Six bays in length, six large vertical-lift doors interspaced on south (main) facade. No decoration. No obvious significant structural alteration to exterior. 
North Bend Ranger District

R6-05-05-DE3

North Bend Ranger Station Radio Shop \#2131: 1937; 29' x 38'; Rectangular, 1story wood-frame, poured concrete foundation, wood-shingled gabled hip roof with projecting gabled porch offset on north (main) facade supported by heavy squaredtimber posts with short slender curving brackets affixed. Horizontal clapboard exterior, vertical boards, battens every other board on gablets and porch pediment. Nine-light sashes singly and in combinations with mullions. Main entry is flanked by nine-light sashes and surmounted by three six-light sashes. Large vertical decoration. No obvious exterior alterations.

R6-05-05-DE4 North Bend Ranger... Station Warehouse

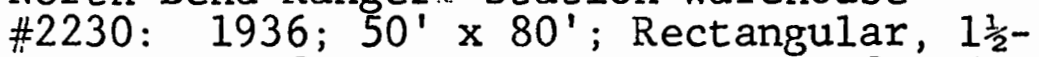
story wood-frame, poured concrete founda-... tion, wood-shingled gabled hip roof, two large gabled dormers on both east and west slopes of roof, part of east (front) wall recessed to cover plank and timber loading dock; roof supported by five heavy squared-timber posts having short, slender curving brackets affixed. Horizontal clapboard exterior, and boards, vertical boards and battens on gablets and dormers. Nine-light sash windows in combinations with mullions. Two-leaf hinged doors extending to height of ground story level, centered on south gable end. No decoration. Helitack practice platform recently installed on north gable end, with no significant structural alteration.

R6-05-05-DE5

Snoqualmie Pass Guard Station, Snow Ranger Residence \#1034: 1939; 1450 sq. ft.; and garage; T-shaped, 2-story wood-frame, coursed, high squared-rubble masonry foundation, high gable roof, projecting center gable on south, center gable porch on north (main) facade. vertical board and batten exterior, ground level, horizontal clapboards second story exterior and south gable end, vertical boards, battens every other board on east and west gable ends above second story, and on center porch 
North Bend Ranger District

R6-05-05-DE5

gable pedinent. Eight-over-eight doublehung sash windows. Main entrance below center gabled porch which is supported by two massive chamfered posts, each exhibiting decorative hand-routing, large curving inset brackets extend from platform surface; porch platform and flight of side stairs of coursed, squared-rubble masonry. Single elegantly described pine tree, cut from two boards, slightly above center on porch pediment. A flat-roofed twovehicle garage and storage structure abuts the lowest level of the north facade; added in 1963, does not appear to substantially alter the structural integrity, although a poured-concrete fire-retaining wall obscures original masonry foundation. Textured corrugated metal roof material added.

R6-05-05-DE6

Lester Guard Station, Residence \#1036:

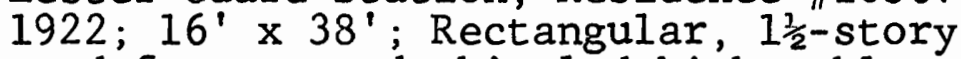
wood-frame, wood-shingled high gable roof, projecting bracketed verges, small gabled porch centered north gable end, offset semi-enclosed gabled end porch, south gable end. Horizontal shiplap exterior, end boards. Nine-over-one doublehung sash windows. No decoration. No obvious exterior alteration. Depression-era wood-slab and peeled log post station sign in landscaped planting.

R6-05-05-DE8

Lester Guard Station Warehouse \#2232:

1934; $2500 \mathrm{sq}$. ft.; Rectangular, woodframe, poured concrete foundation, woodshingled mediun gable roof, verges projecting with brackets. Horizontal shiplap exterior, end boards. Six-verticallight sash windows paired with mullions. Seven bays in length, seven large slideopening doors of narrow vertical shiplap reinforced, interspaced on east (front) elevation. No decoration. No obvious structural alteration to exterior. 
North Bend Ranger District

R6-05-05-DE9

Lester Guard Station, Gas and Oil House \#2532: 1934; 12' x 16'; Rectangular, nailed frame, poured concrete foundation, medium gable roof. Corrugated sheet metal exterior and roof material. Sixvertical light sash windows. Singleleaf wood-panel doors, center north (front) elevation and offset on east gable end. No decoration. Atypical building material. 
MT. BAKER-SNOQUALMIE NATIONAL FOREST

White River Ranger District

R6-05-07-DEI

Camp Sheppard Hut: $1940 ; 24^{\prime} \times 48^{\prime}$; Rectangular, 1-story wood-frame, low gable roof. Horizontal board exterior. Four and six-light single sash windows. Shedroofed hood above center entry on west gable end, wood platform with railing, plain, straight wood steps. (Constructed at Cispus or North Bend CCC shop; located at Ranger Creek CCC Camp, 1941, removed to present location 1953.)

R6-05-07-DE-R1 Silver Springs Community Kitchen: 1937; $12.6^{\prime} \times 18^{\prime}$; Rectangular, peeled $10 \mathrm{~g}$ construction, concrete platform, split-shake gable roof. Four massive peeled log supports, with equal diameter cross-members having hewn and square-sawn ends, large-diamter log exterior roof framing; single horizontal log rail supported by short log post at each end on north gable end; large random-rubble exterior chimney informal random-rubble wall to threefoot leve1 extending across south gable end; longitudinal sides open. Overall massive appearance; no obvious alterations.

$\mathrm{R} 6-05-07-\mathrm{DE}-\mathrm{R} 2$

Silver Springs Bridge: 1936-37; log footbridge, having two to three large-diameter logs spanning stream, hewn logs crosswise equidistant to which plank surface, peeled log foot rails and hand-rail on downstream side are affixed. Hand-rail of peeled poles is braced at each cross-log. Cross-stacked log embankment supports east end of bridge; approaches flanked by combinations of three peeled uprights of staggered heights, having hewn and squaresawn ends. (A. D. Taylor describes footbridge as well-designed.)

R6-05-07-DE-R3 The Dalles Community Kitchen: 1937; 24' $x$ 42'; Rectangular, peeled log construction, concrete platform, split-shake high hipped roof. Large-diameter log supports, two at each corner, two additional log posts on each elevation, all having 
White River Ranger District

R6-05-07-DE-R3 straight peeled brackets. Large, informal, coursed-rubble open hearth fireplace and stoves, with interior chimney located in middle of shelter beneath the north end of the roof ridge. Low railing of two large-diameter logs stacked, between large uprights. Roof materials replaced by Y.A.C.C., 1978. No obvious alterations.

R6-05-07-DE-R3 The Dalles Community Kitchen: 1937; 24' $x$ 42'; Rectangular, peeled log construction, concrete platform, split-shake high hipped roof. Large-diameter log supports, two at each corner, two additional log posts on each elevation, all having straight peeled brackets. Large, informal, coursed-rubble open hearth fireplace and stoves, with interior chimney located in middle of shelter beneath the north end of the roof ridge. Low railing of two large-diameter logs stacked, between large uprights. Roof materials replaced by Y.A.C.C., 1978. No obvious alterations. 
Columbia Gorge Ranger District

R6-06-04-DE-R1 Wahkeena Falls Community Kitchen:

Rectangular, post and beam construction, log trusses, lintels, cross members, purlins and rafters, hewn and squared ends, split shake medium gable roof, poured concrete foundation, flagstone floor surface. Twelve $12 \times 12$ timbers rest on three-foot solid stone railing, coursed rubble, on east and west gable ends and south (main) facade. Center entrances, east and west gable ends and south facade. Gable ends are enclosed with wall shakes. North wall is enclosed, coursed rubble masonry to four foot level, vertical board and batren to eaveline, center coursed rubble exterior chimney drafts central open hearth fireplace and two side stoves. Two square window openings flank chimney on north wall. In -excellent condition. Original furnishings survive.

R6-06-04-DE-R6 Eagle Creek Community Kitchen: Rectangular, post and beam construction, log trusses, lintels, cross members, purlins and rafters, split shake medium gable roof, flagstone floor surface. Ten large diameter logs support roof, rest on three foot solid stone railings, coursed rubble, on north, south and west elevations. Center entries, north and south gable ends, west (main) facade. Gable ends enclosed, vertical boards, corner notched, battens. East wall is enclosed, coursed rubble masonry to four feet level, wall shakes to eaveline, center coursed rubble exterior chimney drafts central stove. In very good condition, similar in design to Wahkeena Falls shelter. 
R6-06-04-DE-R11 Eagle Creek Comfort Station: 1936; Rectangular, wood frame, split shake medium hip roof, square hipped cupola, center ridgeline, center gabled porch entries, east and west elevations, enclosed by battered, coursed rubble solid railing surmounted by heavy squared timber posts, chamfered and hand-routed. Exterior materials, battered coursed stone wall to window level, six six-light horizontal casements interspaced with heavy squared timber posts, chamfered, pegged and routed. Remaining exterior wall space filled by vertical split board siding. $10^{\prime} \times 15^{\prime}$ entrances flagged. Diagonal boards in chevron pattern on center gable pediments, each with single outsized pine tree centered. Varnished vertical board doors each exhibit two narrow, complex pine trees, equidistant. Interior vertical boards, cement slab floor, flush toilets.

R6-06-04-DE-E1

Eagle Creek Suspension Bridge: 1936; Approximately 175 feet in length. Towers of $12 \times 12$ beams with $3 \times 10$ 's and $10 \times 12$ 's as supports, resting on concrete piers on each end. Walkway is suspended from iron rods hanging from one inch steel cables which run over towers and are anchored on bank. Iron rods are connected to $8 \times 8$ beams under the width of bridge at regular intervals. Across these beams, two rows of $3 \times 10$ planks, each about 15 feet long, run vertically, bolted together. The walkway is laid on this framework, of $3 \times 10$ planks, secured by $6 \times 6$ beams. Simple $2 \times 4$ handrails, 3 feet height. 
NT. HOOD NATIONAL FOREST

Estacada Ranger District

R6-06-05-DE-R1 Bagby Hot Springs Bath House: 1939;

Rectangular, wood frame using split logs, vertical log pier foundation, split shake high gable roof, anterior wall, east elevation, recessed to form covered porch extending length of structure, supported by peeled poles of slightly dissimilar dimension. Long wall shake exterior. Porch fioor and interior flooring of five separate stalls is of smooth planed lumber. Rough board and batten doors access stalls. Each stall has a tub hand hewn from a single cedar log. A trough carries hot water from the spring along the west elevation of the building. Water, regulated by carved wooden plugs, drains from the trough into each tub. Each stall has an open window on the east facade, one has shutters. Each-stall is furnished with a small wooden-bench and many pegs. Multi-level plank deck recent addition to south elevation. 
Hood River Ranger District

R6-06-06-DEI Parkdale Ranger Station Ranger's Residence 非1057: 1939; 34'x28'; Rectangular, 2-story wood-frame poured concrete foundation, wood-shingled high gabled roof, center porch gable, south facade, smail enclosed gabled porch, offset, north elevation, two gabled dormers south slope, one large shed-roofed cormer north slope of roof. Exterior end chimney, west gable end of large, coursed, squaredrubble stone masonry. Wall shake exterior. Single sash window of thirty lights, muliion window with two divisions of eight vertical lights each, six-over-one doublehung sash windows. Main entry is a semicircular arch of radiating brick voussoirs with keystone; two straight brick steps to porch platform. No decoration: No exterior material alteration; small shedroofed lean-to, wall-shake exterior, abuts north elevation, offset. A narrow woodframe buttress-iike extrusion, wal1-shake exterior, extends to second story level offset on east gable end.

R6-06-06-DE2

Ranger Residence Garage 非541: 1939; $20^{\prime} \times 24^{\prime}$; Rectangular, $1 \frac{1}{2}$-story wood-frame, poured concrete foundation, wood-shingled high gable roof, flemish-bond brick exterior end chimney, center north gable end. Wall-shake exterior. Six-horizontal and six vertical sash windows. Two vertical. board, reinforced, slide-opening doors, south gable end; two vehicle capacity. Loft room, upper level. No exterior material alteration; small shed-roofed lean-to abuts north gable end, offset. No decoration. 
R6-06-06-DE3

Parkdale Ranger Station office 非2005: 1939; $24^{\prime} \times 42^{\text {P }}$; Rectangular, 1-story woodframe, poured concrete foundation, basement, wood-shingled medium gable roof, center porch gable, south facade, supported by pairs of squared-timber posts with long curving inset brackets. Wall-shake exterior, vertical boards, battens every other board on all gable ends. Six-oversix double-hung sash windows, singly and in combinations with mullions. Single, large simple pine tree logo cut from two boards, center, porch gable pediment. Wood-frame, shed-roofed fiberglass entrance above basement level door, concrete porch platform, side steps, center north elevation with elevated fiberglass walk connecting office with adjacent building. Additions do not appear to have resulted in significant structural alteration; architectural integrity largely intact.

R6-06-06-DE4/DE5 Parkdale Ranger Station Warehouse/ Blacksmith Shop 非212, 非1308: 1939; $60^{\prime} \times 40^{\prime} \times 24^{\prime}$; L-shaped, 1-story wood-frame, poured concrete foundation, medium gable with intersecting gable on north end. Wall-shake exterior. Four-over-four double-hung sash windows, singly and in combinations with mullions. No decoration. Fiber-glass shed roof above rear entrance, offset west elevation. Composition shingle roof material. Shed-roof open storage extends length of north elevation. Single divided structure formerly housed warehouse facilities and blacksmith shop; now functions as warehouse and recreation office. No significant structural alterations to exterior. 
Hood River Ranger District

R6-06-06-DE6

R6-06-06-DE7

$\mathrm{R} 6-06-06-\mathrm{DE} 8$

R6-06-06-DE9
Parkdale Ranger Station Machine Shop and Storage 非103: 1939; 56'x36'; Rectangular,

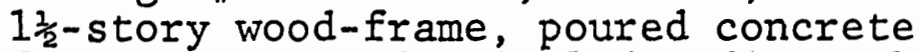
foundation, wood-shingled medium gabled roof. Wall-shake exterior. Nine-light sash windows. Large flat door structural opening, offset on east (main) facade. No decoration. Structure connected to office building by elevated fiberglass covered walkway. No other obvious structural or material alteration to exterior.

Parkdale Ranger Station Fire Warehouse

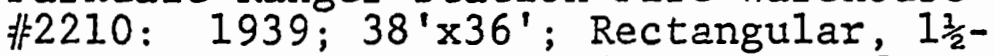
story wood-frame, poured concrete foundation, wood-shingled medium gabled roof, east slope extending to single pitch shed shape. Wall-shake exterior. Six-horizontal-light sashes, lower level, nine light sashes upper level. Large vertical board, reinforced, slide-opening door offset on west (main) facade. Shed-roofed open storage abuts the width of north gable end and length of east elevation. No significant structural alterations to exterior.

Parkdale Ranger Station, Road Maintenance Office 非 059: 1939; $22^{\prime} \times 30^{\prime}$; Rectangular, 1-story wood-frame, poured concrete founcation, medium gabled roof verges project, with brackets, small gable porch offset on west (main) facade. Wall-shake exterior. Nine-light sash windows. No decoration. Formerly a residence, converted to office use. No obvious exterior structural alteration; composition shingle roof material.

Parkdale Ranger Station Gas House 非505: 1939; 16'x26'; Rectangular, wood-frame, poured concrete foundation, medium gabled roof. Wall-shaked, gable ends above eaveline. No windows. Below the eaveline, original exterior wall materials replaced with Texture 1-11 grooved plywood siding, vertical application. Composition shingle roof material. No decoration. 
MT. HOOD NATIONAL FOREST

Zigzag Ranger District

R6-06-09-DE1

Upper Sandy Guard Station: 1935;

Rectangular, log cabin, cemented stone foundation, random rubble masonry bay on east elevation, wood shingled medium gable roof, coursed rubble interior chimney straddles ridgeline, off-set. Exterior walls enclosed by horizontally stacked peeled logs, saddle notched, ends hewn and squared, corners buttressed. Logs are not chinked: Single entry offset on south (main) facade. Six-light sash windows, functional board shutters. Vertical board door has hand-forged strap hinges and latch. In excellent condition. No exterior alteration apparent.

R6-06-09-DE-R1 Tollgate Community Kitchen: Rectangular, post and beam construction using large diameter peeled logs and poles, flagstone platform and entry, split shake high hip roof, center gabled porch entry on north elevation. Twelve log uprights support roof, shelter enclosed by two horizontal pole railing, center coursed squaredrubble exterior chimney on south elevation drafts central open hearth fireplace and two side stoves. Half-log benches are built into opposing sides of center gabled entry. Gable pediment is enclosed by vertical peeled poles, beveled and mitered to fit. In good condition. Fiberglass skylights installed in south (rear) roof slope on either side of chimney. Considerable vandalism to fabric including charred structural members. 
Lamonta Compound, Supervisor's Office

R6-07-SO-DE1

R6-07-SO-DE2

R6-07-SO-DE3

R6-07-SO-DE4
Storage Shed: 1937?; Rectangular, 1-story wood-frame, wood-shingled medium gable roof with shed roofed open porch extending the width of east gable end (main) facade. Vertical board and batten exterior. No decoration. May have been removed to present location from 1937 CCC side camp.

Carpenter Shop: 1937?; Rectangular, 1-story wood-frame, wood-shingled medium gable roof, concrete pier foundation. Vertical board and batten exterior. Twelve-light sash windows. No decoration. May have been removed to present location from 1937 CCC side camp.

Office/Warehouse 非2006: 1933-34; 4,000 sq. ft.; Rectangular, 2-story wood-framed, poured concrete foundation with coursed, squared-rubble stone veneer, wood-shingled medium gable roof, two offset gables on north (main) facade, two large gableroofed dormers on south (rear) roof slope. Gable roofed porch extends from one offset gable supported by pairs of squared timbers, open flagged platform with coursed, squaredrubble facing and steps. Two loading docks recessed on south facade. Horizontal clapboard exterior, vertical board and batten on all gable ends. No decoration. No obvious exterior alteration.

Maintenance Shop 非, 非101: 1933-34; 4,000 sq. ft.; Rectangular, 2-story woodframed, wood-shingled medium gable roof, two offset gables on west (main) facade, two gable-roofed dormers on west slope of roof. Single brick chimney offset on west slope of roof. Horizontal clapboard exterior, vertical board and batten on all gable ends. Six and nine-light sash windows singly or in combinations with mullions. No decoration. No apparent exterior alteration. 
Lamonta Compound

R6-07-SO-DE5

Oil and Gas House 非, 非2502: 1933-34;

$600 \mathrm{sq}$. ft.; Rectangular, 1-story woodframed, squared-rubble stone faced

foundation, wood-shingled medium gable roof, center portion of west roof slope extends to form porch cover, supported by large squared-timber posts with affixed curving brackets. Coursed, squaredrubble stone faced loading docks extend across south gable end. Horizontal clapboard exterior, vertical boards, triangular corner cuts with battens on gable ends, including porch. Six-light sash windows with mullions. No decoration. No apparent exterior alteration.

R6-07-SO-DE6

Vehicle Storage 非, 非301: 1933-34; 4,000 sq. ft.; Rectangular, wood-framed, wood-shingled medium gable roof. Horizontal clapboard exterior, vertical board, triangular corner cuts, with battens on gable ends. Six bays in length, vertical board slide-open doors interspaced with squared-timber posts with short straight inset brackets. No decoration. No obvious exterior alteration. 
Paulina Ranger District

R6-07-02-DE1

$\mathrm{R} 6-07-02-\mathrm{DE} 2$

R6-07-02-DE3
Rager Ranger Station Barn: 1936; 16'x30'; Rectangular, wood-framed, medium gable roof two-horse stable. Horizontal clapboard exterior, vertical boards with triangular corner cuts on gable ends. Single, well-shaped pine tree cutout from single board centered below peak of roof on each gable end. Shed-roofed open leanto attached to west elevation. Loading dock of cement blocks added to north gable end. Textured metal roof material.

Rager Ranger Station, Old Office (now Rec. Hal1) 非2002: 1936; $1150 \mathrm{sq.} \mathrm{ft.;} \mathrm{Cruci-}$ form, 1-story wood-framed, poured concrete foundation, medium gable roof with center cross gable. Horizontal clapboard exterior, vertical boards with triangular cut corners on all gable ends. Main entrance is offset, recessed in south cross-gable end. Porch supported by squared-timber posts with short, curving inset brackets, lintel is carved in a scroll pattern. Six-over-six double-hung sash windows singly or in combinations with mullions. One well-defined pine tree cutout of single board centered below peak of roof on east and west gable ends. Textured metal roof material. No structural alteration to exterior.

Rager Ranger Station Shop 非302: 1936; $1600 \mathrm{sq}$. Ft.; Rectangular, wood-framed, medium gable roof. Horizontal clapboard exterior, vertical boards with triangular corner cut on gable ends. Four large slide-open doors with windows on west (front) elevation. Nine-light sash windows. Single, well-defined pine tree logo cutout from one board centered below peak of roof on north and south gable ends. Textured metal roof material. 
OKANOGAN NATIONAI FOREST

Conconully Ranger District

R6-08-01-DEI Conconully Work Center Bunkhouse 非1300:

1934; Rectangular, 1-story wood-frame, uncoursed rubble-concrete foundation, medium gable roof. Single random rubble interior chimney offset on ridgeline. Horizontal clapboard exterior, vertical boards, lower ends rounded on gable ends. Six-horizontal-light single sashes, six-over-six double-hung sashes.

Center gable porch on east gable end, supported by large squared-timber posts, straight inset brackets. Random rubble open platform, flagstone surface. Two graceful, well-defined pine tree cutouts flank center porch gable on east gable end, single simple pine tree centered on porch pediment. Original office (Ranger Station) was removed to present location by CCC and remodeled for use as bunkhouse. Roof material of textured metal.

R6-08-01-DE2 Conconully Work Center Barn 非400:

1934; Rectangular, wood-frame, gambrel roof, extending to shed-roof on lean-to incorporated into original construction of east elevation. Horizontal shiplap exterior, end boards. Large slideopening door offset on south facade, enclosed feed and tack rooms on north interior wall. No decoration. Leanto extending length of east elevation formerly open, width of one bay, now enclosed, vertical board and batten. Textured metal roof material.

R6-08-01-DE3

Conconully Work Center Gas House 非2500: 1937; Rectangular, wood-frame, poured concrete platform, medium gable roof. Anterior (north) wall recessed to form porch, supported by large squared-timber posts, curving hewn brackets affixed. Horizontal clapboard exterior, vertical board, lower ends rounded on gable ends. Single simple pine tree cutout, center north gable end. Textured metal roof material. 
R6-08-01-DE4

R6-08-01-DE5
Conconully Work Center Office 非2001:

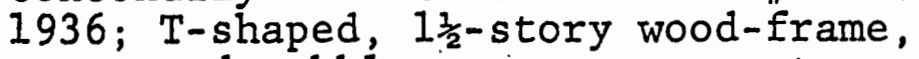
uncoursed-rubble veneer, concrete foundation, poured concrete basement, medium hip roof with gabled hips on cross gable, center gable porch roof. Single coursed rubble interior chimney with stone cap on west (rear) slope of roof. Horizontal clapboard exterior, vertical boards, lower ends rounded on all gable ends. Six-over-six doublehung sashes, singly and in combinations with mullions. Narrow center gable porch supported by six large squared-timber posts, center posts having straight, mitered brackets affixed. Open stone porch platform, flagstone surface, three straight stone steps. One complex pine tree cut from single board centered on porch gable pediment. Textured metal roof material.

Conconully Work Center Warehouse 非200:

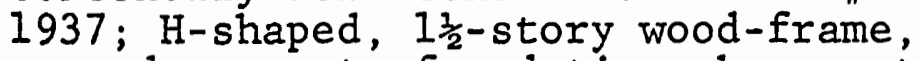
poured concrete foundation, basement and left, medium gable roof, cross gables on north and south, two gabled dormers on east slope of main gable. Single rubble stone, metal capped interior chimney straddles main ridgeline, offset.

Horizontal clapboard exterior vertical boards, lower ends rounded on all gable ends. Twelve-light sashes, singly and in combinations with mullions. Large twoleaf slide-opening doors centered in each cross gable end, and in center of east facade. Rectilinear design of three pine tree cutouts, centered on each cross-gable end; two welldefined trees flank a larger center tree. A cement loading dock on the south crossgable end replaces a wooden loading dock; additional multi-light windows added to west end of north cross-gable. 
R6-08-01-DE6

Various buildings of this well-maintained compound are enclosed by fences which

feature substantial random-coursed rubble masonry posts of native stone. The

fence posts were erected in 1936, and are of a scale and proportion in keeping with the dimensions of the buildings, and compliment the stone masonry utilized in the paths, foundations and chimneys throughout the compound. The boards used in the fencing are not original but are entirely appropriate, repeating the dimensions and texture of the horizontal clapboard building exterior. 
OKANOGAN NATIONAL FOREST

Tonasket Ranger District

R6-08-03-DE1 Ranger Station Office: 1934-36;

Rectangular, 1-story wood-frame, low gable roof with projecting center gable porch. Horizontal clapboard exterior. One-over-one double-hung sashes and nine-light single sashes with mullions. Single brick chimney centered on east slope of roof. Roof material now is composition shingles. No decoration.

$\mathrm{R} 6-08-03-\mathrm{DE} 2$

Lost Lake Guard Station: 1940; T-shaped, 1-story wood-framed, medium gable roof with intersecting gable on south end and attached, gable-roofed garage on north. Horizontal clapboard exterior, vertical board and batten on all gable ends. Eight-light and twelve-light single sashes, singly and in combinations with mullions. Main entrance recessed, a porch formed by extension of main roof line supported by two heavy squaredtimber posts with straight timbered brackets. Two chimneys straddle the main ridgeline. No apparent exterior alteration: No decoration.

R6-08-03-DE3 Lost Lake Bunkhouse: 1934; Rectangular, 1-story, concrete footings, medium hip roof. Peeled, hewn logs, dovetail or box corners, chinking regular-small round poles of uniform size and mortar. Twosash windows. Single offset chimney straddles ridgeline. Well-maintained. No apparent exterior alteration. No decoration.

R6-08-03-DE-CCC1 Lost Lake CCC Camp: Permanent structures erected by CCC enrollees and local contractors for housing enrollees and administering camp.

R6-08-03-DE-CCC1A Bunkhouse: Rectangular, 1-story, woodframe, medium gable roof. Vertical board and batten exterior, horizontal clapboard on gable ends. Six-light single sash windows. Well-maintained. No obvious exterior alteration. No decoration. 
Tonasket Ranger District

R6-08-03-DE-CCC1B Bunkhouse: Rectangular, 1-story, wood-frame, medium gable roof. Vertical board and batten exterior, horizontal clapboard on gable ends. Six-light single sash windows. Well-maintained. No obvious exterior alteration. No decoration.

R6-08-03-DE-CCC1C Shower House: Rectangular, 1-story, wood-frame, medium gable roof. Horizontal shiplap exterior. Six-over-six doublehung sashes and nine-light single sash windows. No decoration. No obvious exterior alteration.

R6-08-03-DE-CCC1D Toilet Building (latrine): Rectangular:

1-story, wood-frame, medium gable roof. Horizontal shiplap exterior. Nine-light single sash windows. Entrance screens of horizontal shiplap, north and south gable ends. No decoration. No obvious exterior alteration.

R6-08-03-DE-CCCIE Dining Hall: L-shaped, 1-story, woodframed, medium gable roof. Horizontal shiplap exterior wood latice extending two vertical feet around building anterior. Nine-light single sash window. Wood loading dock on south elevation, wood stairs to entrances on west and north elevations. No decoration. No obvious exterior alteration. Well-maintained. 
Winthrop Ranger District

R6-08-05-DE 1

Winthrop Work Center, Office 非005:

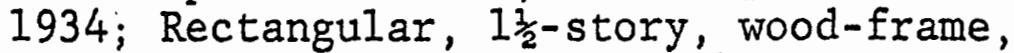
poured concrete foundation, basement, wood-shingled medium gable roof, single shed roof dormer, west (front) slope, two shed roof dormers, east slope, center gable porch. Single stretcher-bond brick interior chimney offset on west roof slope. Wall-shake exterior. Oneover-one double-hung sash windows.

Center gable porch roof supported by two large squared-timber posts, vaulted ceiling, pediment, rounded arch.

Each window flanked by decorative vertical board shutters, each exhibiting a single, simple pine tree logo. Battered dry masonry retaining wall surrounds office.

R6- 08-05-DE2

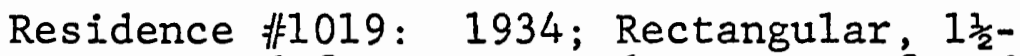
story, wood-frame, poured concrete foundation, basement. Medium gable roof with offset gable on north end. Stretcherbond brick exterior end chimney, corbeled cap, west gable end. Wall-shake exterior, vertical boards, triangular corner cuts on north offset and porch gable ends. Mullion window, north facade, has two-light center sash, flanked by four-over-four double-hung sash windows and surmounted by transome lights; sixover-six double-hung sashes, singly and. in combinations with mullions. Enclosed center entry, semi-circular structural opening; uncovered cement porch platform, straight side steps, wrought iron railing with pine tree design incorporated. Decorative vertical plank shutters, each having a single simple pine tree cutout, center, upper third. Random coursed, battered, dry masonry retaining wall below house. Textured metal roof material. Garage formerly beneath house, now enclosed, poured concrete wall. 
Winthrop Ranger District

R6-08-05-DE3

Residence 非1020: 1934; Rectangular, $1 \frac{1}{2}$-story, wood-frame, poured concrete foundation, basement. Medium gable roof with offset gable on north end.

Stretcher-bond brick exterior end chimney, corbeled cap, west gable end. Wallshake exterior, vertical boards, triangular corner cuts on north offset and porch gable ends. Mullion window, north facade, has two-light center sash, flanked by four-over-four double-hung sash windows and surmounted by transom lights; six-over-six double-hung sashes, singly and in combinations with mullions. Enclosed center entry, gable roof, semi-circular structural opening; uncovered cement porch platform, straight side steps, wrought-iron railing with pine tree design incorporated. Decorative vertical plank shutters, each having single, simple pine tree cutout, center, upper third. Textured metal roof material. Garage formerly located beneath house; now enclosed, poured concrete wall, single-leaf door and aluminum casement window added.

R6-08-05-DE4

Garage 非208: 1935; Rectangular, 2-story, wood-frame, poured concrete foundation, medium gabie roof, wood-shingled gableroofed porch and loading dock abutting east gable end. Horizontal shiplap exterior, end boards, wall-shakes east gable end, porch gable pediment. Six light single-sash windows, horizontal and vertical. Five bays in length, five large siide-opening doors on north elevation. No decoration. Textured metal roof material on main gable. 
Winthrop Ranger District

$\mathrm{R} 6-08-05-\mathrm{DE} 5$

R6-08-05-DE6

Warehouse 非205: 1936; T-shaped, 1-story, wood-frame, random rubble veneer on poured concrete foundation, wood-shingled low hip roof with gabled hips on east and west ends, and truncated hip on the north-projecting porch roof. Wall-shake exterior; vertical board and batten on gablet ends; vertical boards, angular cut with battens every other board on porch pediment. Twelvelight single sash windows, singly or in combinations with mullions. Random coursed-rubble loading dock on west gable end, gabled hip extends to form porch, supported by four large squared-timber posts. Truncated hip center porch roof supported by eight large squared-timber posts. Two well-defined pine tree cutouts, rectilinear placement, on porch pediment. No obvious structural or material alterations.

Gas House 非2504: 1936; L-shaped, woodframe, random rubble veneer on poured concrete foundation, medium gable roof with cross gable on south end; anterior (north) wall of cross gable recessed to form porch, supported by six large squared-timber posts with short, curving flush brackets; enclosed loading dock on west gable end, open on north facade. Wall-shake exterior, vertical board and batten on west gable end, horizontal clapboard on south gable end of cross gable, vertical boards, angular cut, with battens every other board on north gable end of cross-gable. Single, wellshaped pine tree cutout, center, north gable end of cross-gable. Extension of west-end loading dock and enclosure a later addition/alteration. 
R6-08-05-DE7

Landscape Features: The Winthrop Work

Center, formerly the Winthrop Ranger

Station, is extensively and effectively

landscaped with battered, random-coursed native stone dry-masonry retaining walls, flagged-stone steps and walks. The compound is separated from State Highway 20 by a stone-masonry post and rail fence (one rail of two now remaining) which was built by the CCC in 1935 . The posts are in good proportion to the structures in the compound and appropriate to their surroundings. The stone masonry of the posts exhibit an uncoursed assemblage of cut and fitted native lava rock with natural surfaces. 
OLYMPIC NATIONAL FOREST

Quilcene Ranger District

R6-09-02-DEI Forest Service Residence \#1009: 1934;

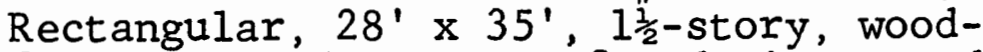
frame, poured concrete foundation; woodshingled medium gable roof with two gabled dormers on south slope; exterior brick chimney on west gable end; woodshingle exterior, vertical board and batten on gable ends. Fenestration regular--three-over-one double-hung sash windows with mullions. Main entrance at center of south facade, narrow concrete platform, open, gable porch roof with vaulted ceiling--pediment arched. No decoration. No apparent exterior alteration. Wellmaintained, excellent condition.

R6-09-02-DE2

Old Quilcene Ranger Station Office \#2002: 1934; Rectangular, $37^{\prime} \times 24^{\prime}$, 1 $\frac{1}{2}-$ story, wood-frame, poured concrete foundation, basement; wood-shingle medium gable roof, two gable roof dormers on front slope of roof; brick chimney off-center on rear roof slope; wood-shingle exterior; threeover-one two sash windows--mullions on dormer windows only; partially enclosed porch with gable roof projecting from below eave line. No decoration. No obvious exterior alterations. Wellmaintained.

R6-09-02-DE3

Quilcene Ranger Station Shop \#2103: n. d.; U-shaped, 49' $\times 21^{\prime}$, wood-frame, concrete foundation; wood shingle medium gable roof with projecting offset gables on north and south, three gable-roofed dormers on east roof slope. Horizontal clapboards, vertical board and batten on all gable ends--vertical boards rounded at lower end. Multi-light one and two sash windows, with mullions. Large doors on west elevation, north, south gable ends and on each of projecting gables-operating by slide or two-leafed hinges. One offset gable has a vertical slide door of corrugated metal. Three equal sized complex-design pine tree symbols cut out of vertical boards on each major gable 
Quilcene Ranger District

R6-09-02-DE3

R6-09-02-DE4

R6-09-02-DE 5

R6-09-02-DE6

R6-09-02-DE7

Equipment Storage \#2302: n.d.; Rectangular, $20^{\prime} \times 32^{\prime}$, peeled pole construction-six bays long, three bays deep--pole supports on cement footing. Open; woodshingle medium gable roof. Southwest corner enclosed--horizontal board exterior. No decoration. No apparent alteration.

R6-09-02-DE8

Gas House \#2500: 1939; Rectangular, 8' x $13^{\prime}$, wood-frame, concrete foundation; woodshingle low gable roof with projecting center porch gable on main (east) facade, center gable on rear roof slope; vertical board and batten on east and west elevations, horizontal clapboards on gable ends; eighteen-lights vertical-single sash with mullions on gable ends--twelve lights-single sash on main facade. Vertical slide aluminum door on rear loading dock entrance. Shed-roofed lean-to 
Quilcene Ranger District

R6-09-02-DE8

abutted to southwest corner-horizontal clapboard exterior. Single complex pine tree design cut out of two vertical boards on porch pediment.

R6-09-02-DE-R1 Camp Tony Shelter \#1931: n.d.; Adirondacktype shelter of peeled pole construction; shake roof with comb ridge treatment; exterior wall shakes. Appears structurally sound; includes a handcrafted rough plank and round log table or bench.

R6-09-02-DE-R2 Sink Lake Shelter \#1906: n.d.;

Adirondack-type shelter of peeled pole construction; rear roof joists project beyond front slope of roof of wood shakes; exterior wall shakes. Appears structurally sound; some roof shakes missing; handcrafted bench and table present. 
OLYMPIC NATIONAL FOREST

Quinault Ranger District

R6-09-03-DE1 Norwood Barn \#2400: n.d.; Rectangular, 2story, wood-frame, concrete foundation; bellcast gambrel roof wood shingled; wood-shake exterior; four light single sash windows. Two-leaf hinged vertical board entrance and hay door on north gable end. No obvious exterior alteration. No decoration. Good condition.

R6-09-03-DE-R1 Falls Creek Campground - Community

Kitchen: Rectangular with split-shake hipped roof. Smooth-surface randomcoursed stone buttress-like supports at each corner with bracketed peeled pole posts spaced between; enclosed to the three-foot level with random-coursed stone wall. Entrance on west elevation. Originally had central fireplace and chimney--now removed; structure reroofed with like materials.

R6-09-03-DE-R2 Mulkey Trail Shelter \#1916: Adirondacktype shelter of peeled pole construction. Split-shake roof; vertical plank exterior with some hand-split battens. Some exterior materials dislodged or missing.

R6-09-03-DE-R3 West Fork Humptulips Trail Shelter \#1917: Adirondack-type shelter of peeled pole construction; split-shake roof; rough vertical plank exterior. In deteriorated condition with roof and exterior wall materials missing. 
Soleduck Ranger District

R6-09-05-DE1

$\mathrm{R} 6-09-05-\mathrm{DE} 2$

R6-09-05-DE3

R6-09-05-DE4
Snider Work Center-Residence 非1027:

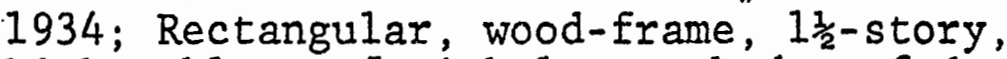
high gable roof with large shed-roofed dormer on front slope of roof. Shedroofed addition to rear elevation; gable roofed porch over main entrance. Sixover-one sash windows in combination, without mullions. Horizontal lapped siding exterior. No decoration.

Snider Work Center-Shop 非102: 1934; Rectangular, wood-frame, 1-story, medium gable roof of wood-shingles; horizontal shiplap exterior; twelve-light single sash windows, singly and in combination with mullions. Two large, reinforced vertical board doors - slide open. No decoration. No obvious exterior alterations.

Snider Work Center-Warehouse 非2207: 1934; Rectangular, wood-frame, 1-story, medium gable roof of wood shingles; horizontal shiplap exterior, wood corner trim; horizontal six-light single sash windows; loading dock off-center on east elevation; large vertical-board slideopening door - center of south elevation with loading dock. No decoration. No obvious exterior alteration.

Snider Work Center-Equipment Storage 非308: 1936; Rectangular, wood-frame, 1-story, medium gable roof-wood shingled; horizontal shiplap exterior; four bays open storage on north elevation; twelvelight single-sash windows. No decoration. No obvious exterior alteration. 
ROGUE RIVER NATIONAI FOREST

Applegate Ranger District

R6-10-01-DE1 Star Ranger Station, o1d Office 非004:

1934; Rectangular, I-story wood frame,

2-room office, poured concrete foundation, wood shingled medium gable roof, projecting center gable porch supported by $8 \times 8$ squared timber posts, raised plank platform, straight plain steps, vertical board railing with random circular cutouts.. Narrow rounded shiplap exterior, end boards. Six-over-one double-hung sash windows. Flush fasica board, boxed eaves. No decoration. No exterior alterations, interior wall partition removed to form single conference room.

R6-10-01-DE-R1 McKee Bridge Community Kitchen: Rectangular, wood frame, post and beam construction using peeled logs and poles, poured concrete slab floor and foundation, split shake medium gable roof, shakes nailed to parallel 10" boards over 6-8" pole roof joists. Corner posts and entry surrounds are 20 " diameter logs, with side and corner pole brackets angled to fit in long shallow ax-hewn notch. Low open railing, two horizontal logs on east and west gable ends on south elevation. Formerly railing had short 8" diameter uprights equidistant between horizontal members; a few remain on west gable railing. Upper rail has flattened hewn surface. A wet sink was originally located at the center of the east railing, has been removed and the space filled with wood slab shaped to conform with railing. A massive stone chimney using large round boulders in uncoursed random pattern partially occupies north elevation, open between chimney sides and corner posts. Three stoves radiate from center chimney, with iron grates, one retains U.S.F.S. shield shaped door, reads "Please Burn Ali Garbage". Three original picnic tables remain, intact, half-log surfaces on round log bases, half-log benches attached and braced by pole cross member. 
Applegate Ranger District

R6-10-01-DE-R1 Approximately twenty yards east of the shelter is a stone cistern, of widely spaced large round boulders, mortared. Oblong in shape, cistern is three feet high with a tightly fitting cement cover. Pipe fixtures are missing, cistern not in use.

R6-10 $=01-D E-R 2$ McKee Bridge Campground-Picnic Area: Campground lies adjacent to the Applegate River on the north bank, downstream (east) from covered bridge (McKee Bridge). Extensively landscaped with battered dry wall masonry and cut and fitted mortared stone retaining walls along river bank, carefully laid masonry steps with low solid masonry railing access beach. Adjacent to steps, a semi-circular alcove with fitted river cobbles laid in mortar walls contains a community fire ring, masonry bench, 24" high around alcove wall, on raised terrace above beach. Numerous convertible camp stoves are located throughout the campground--now day use only picnic area--exhibit a variety of masonry textures from large round boulders, informal to carefully cut and fitted, formally arranged and coursed; one stove of informal construction is built into a rock outcrop.

R6-10-01-DE-R3 A community bonfire ring defined by low cut-and-fitted stone border is flanked by four benches of heavy ( $\left.3^{\prime \prime}\right)$ planks on round log bases set into slope, below community kitchen. A single small round open fire ring with metal pipe cooking standard, two pot hooks remaining, is 1ocated in one campsite. Fire ring is defined by a low wall of cut-and-fitted, mortared rock. Retaining walls, alcove bench and community fire ring, stairs and solid railing show remarkable skill and workmanship in stone masonry. Single open fire ring with cooking standard retains integrity and is well-built. Remaining convertible campstoves exhibit a variety of masonry textures and skills, many are obviously repaired. Formerly the facility had a change house adjacent to beach, now missing. 
Applegate Ranger District

$\mathrm{R} 6-10-01-\mathrm{DE}-\mathrm{R} 3$

Wrangle Campground Community Kitchen: ca. 1936; Rectangular, stone and timber construction using peeled logs and poles, split shake medium gable roof, west elevations enclosed by masonry wall, two window openings (three sq. ft.) one on either side of central chimney, solid masonry railing capped by hewn plank, 36" high on north and south gable ends, $24^{\prime \prime}$ high on east (main) elevation, stone coursed with grain vertical. East slope of roof supported by four logs, 18" in diameter, corner and side pole brackets. Gable ends are open except for post and beam framing. Floor is poured concrete slab, diamond pattern impressed. Center fireplace on west wall, having arched opening with radiating voissoirs; native granite is incorporated in masonry, with single square polished block in center of chimney below roughly USFS shield shaped wood plaque--"This Kitchen Is For Community Use. Courtesy Demands That No One Party Use Facilities Exclusively"--lower portions of plaque are obscured by gnawings of rodents. Two angled side stoves with cast iron cooking plates, one retains door (Please Burn A11 Garbage). Northwest corner, two stone supports for a hewn log sink and drain board; currently removed--to be replaced. Southwest corner shows structural damage, with cross members split. Informal landscaping of large granite boulders laid parallel to shelter down slope to the east.

Two convertible campstoves, of informal construction using rounded granite boulders, survive in adjacent campground, with cast iron cooking plate, one retains stove door. Campground is open, with duff-covered floor, among mature Shasta Red Fir. 
Applegate Ranger District

R6-10-0I-DE-R4 Cook and Green Campground: Three stone convertible campstoves survive; of extremely informal construction using dissimilar rounded boulders, some placed in vertical strata rather than horizontal. Iron grates, and cooking plates, shieldshaped stove doors missing.

R6-10-01-DE-R5 Hutton Campground: Three stone convertible campstoves survive; of ashlar-like textures with stepped triangular open hearth warming fireplace abutting the chimney. Basic fabric intact, although obviously repaired, parts missing. 
Ashland Ranger District

R6-10-02-DE-RI Fish Lake Community Kitchen: 1936; $18^{\prime} \times 26^{\prime}$; Rectangular, post and beam construction using logs and poles, split-shake, staggered butts, medium gable roof, pole ridge treatment, poured concrete foundation and slab floor. Corner posts and entry supports are 18" in diameter, with short pole brackets. South elevation is random coursed rubble wall with central chimney. Solid railing, 30 " high on east and west gable ends and across north (main) elevation, long wall shakes affixed to horizontal poles spanning between log uprights, walls then open to eaveline, gable ends enclosed, wall shake exterior. Pole roof joists and purlins project. Lintel logs notched to fit cross members. Central open-hearth fireplace is flanked by two angled stone stoves. A wood plaque is inset in chimney above fireplace - "1936 - Built by Co. 1642 - CCC U. S. Dept. of Agr. - Forest Service". A capped water pipe stands next to east wall. 1939 photograph shows gable ends entirely enclosed, the center span, now open, covered by vertical boards.

R6-10-02-DE-R2 Dead Indian Soda Springs Community Kitchen: 1936 ; 20' $\times 30^{\prime}$; Rectangular, post and beam construction using logs and poles, three large log columns, grouped at each corner, with two uprights at either end of the center section of railing on the long axis and a single log of equivalent diameter on either side of the center entry on each gable end. The low railing, 24 " high, enclosing the structure is a simple balustrade employing horizontal poles separated by vertical sections, equidistant; end notched into the railing cross-member rather than being cupped or grooved to fit. The center sections of railing are double tiered. The foundation and slab are of poured concrete (badly broken on east end). Wood-shingled hipped roof. Central stone chimney, squared rubble, coursed, drafts four camp stoves, 


$\begin{array}{ll}\text { R6-10-02-DE-R2 } & \text { radial arrangement. A wet sink is } \\ & \text { centered in a heavy, sheet-metal covered } \\ \text { plank work surface in the center section } & \text { of the south wall. Four half-log, with } \\ & \text { round base picnic tables, attached bench } \\ & \text { survive in good condition } 1936 \text { photo- } \\ & \text { graphs indicate that original roof } \\ \text { material was split shakes. } & \\ \text { R6-10-02-DE-R3 } & \text { Trail Camp Ski Shelter: 18'3"x29'8"; } \\ & \text { Rectangular post and beam construction } \\ & \text { using poles and medium diameter logs, } \\ & \text { bark on. Split shake high gable roof, } \\ & \text { projecting eaves; open to eaveline, } \\ & \text { enclosed on gable ends by wall shakes } \\ & \text { attached to horizontal boards, widely } \\ & \text { spaced. Structural members braced and } \\ & \text { bracketed. Roof and wall materials } \\ \text { missing from one slope of roof and } \\ \text { one gable end. }\end{array}$

R6-10-02-DE1

Big Elk Road Portal Sign Arm: ca 1935; Single peeled pole with straight pole bracket (small diameter) affixed to tree adjacent to CCC constructed road.

R6-10-02-DE-E1 Big E1k Road: ca 1935; Roadbed, dirt surface visible, curves between tree's opposite irrigation canal. Overgrown and revegetated in places, no longer in use. 
ROGUE RIVER NATIONAL FOREST

Butte Falls Ranger District

R6-10-03-DE1

Butte Falls Ranger Station, District

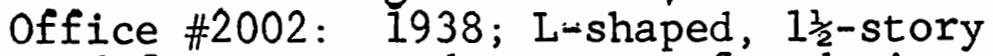
wood frame, poured concrete foundation, coursed cobblestone veneer, wood shingled medium gable roof, projecting cross gable on south, three chamfered beams (ridge pole and lintels) project slightly from gable ends, four gabled dormers on north slope of main gable. Portion of south slope of main gable extends, bellcast, to form porch above main entry, center, east facade, supported by four $10 \mathrm{x}$ 10 squared-timber posts with heavy short curving brackets, affixed. Flagstone porch su-face, four straight, plain stone steps access. A single coursed rubble chimney off-set south slope of main gable, to rear of south projecting gable. Horizontal clapboard exterior to eave line, vertical boards, ends rounded, on all gable ends. Eight-over-eight double-hung sash windows. A single well-shaped pine tree symbol cut from two boards located immediately below apex of roof on east and south gable ends. Interior wall paneling of knotty pine. Addition to rear (west) elevation shows similar clapboard siding and window treatment, but has unfaced concrete foundation.

R6-10-03-DE2

Butte Falls Ranger Station, Residence \#1001: 1935; Rectangular, 1 story wood frame, poured concrete foundation, coursed cobblestone veneer, wood shingled medium gable roof, off-set projecting porch gable on east (main) facade, supported by four $6 \times 6$ squared timber with short curving flush brackets. Projecting bay adjacent to porch. Coursed rubble interior chimney off-set on west slope of roof. Horizontal clapboard, rusticated texture on porch gable pediment. Three chamfered beams (ridge pole and lintels) project slightly from gable ends. Three-over-one doublehung sash windows, six horizontal lights in bay window. No decoration. Shed roofed lean-to, wood shingled, horizontal 
Butte Falls Ranger District

R6-10-03-DE2

R6-10-03-DE3

R6-10-03-DE4 clapboard, abuts west elevation off-set.

Butte Falls Ranger Station, Residence \#1002: 1936; T-shaped, 1 story wood frame, poured concrete foundation, coursed cobblestone veneer, woodshingled medium gable roof, intersecting gable on north, portion of east slope of north gable extends, bellcast, to cover center porch and main entry, supported by two $6 \times 6$ squared-timber posts having short, curving flush brackets, flagstone platform, four straight plain stone steps. Coursed rubble interior chimney slightly off-set on east-facing roof slope. Horizontal cl-pboard exterior to eave line, vertical boards, rounded ends, on gable ends, three chamfered beams project (ridgepole and lintels). Six-over-six doublehung sash windows, singly and in combinations with mullions. Mullion window centered in north gable end has two divisions of twelve lights each surmounted by two divisions of six lights each. Knotty pine interior wall paneling in living room, dining room and interior bedroom, with patterned cellutex ceilings; kitchen and second bedroom finished with plywood and painted. Open hearth fireplace, with floor to ceiling masonry wall. Single well defined pine tree cut out beneath apex of roof on north gable end. Addition to west elevation compatible, with similar exterior wall materials, windows and gable end treatment.

Butte Falls Ranger Station, Ranger's Residence \#1003: 1936; Irregular L-shape, 2 -story wood frame, poured concrete foundation, full basement, window wells, wood shingled medium gable roof with shallow, stepped intersecting gables off-set on the west (main) facade, projecting offset gable on the east elevation forms a 1-story bay; a medium hip extending from the plane of the south gable end forms a covered porch supported by six $7^{\text {"it }} \times 7^{\prime \prime}$ squared-timber posts with short curving flush brackets affixed; raised flagstone 
Butte Falls Ranger District

R6-10-03-DE4

platform; single hipped dormers, offset, located on front and rear slope of main gable. A single coursed rubble interior chimney, off-set on west slope of roof. Horizontal clapboard exterior, with vertical boards on all gable ends, plain ends on north, south and east gables, corner notched on primary west gable, chamfered battens every other board on north and south gables, plain battens every board on east and west gables. Eight-over-eight double-hung sash windows, flanked by vertical board decorative shutters, each with an extremely naturalistic pine tree routed into wood. Bay window has six large vertical panes. Single pine tree cut out partially obscured on both north and south gable ends beneath apex of roof. Knotty pine interior wall paneling in entry hall, dining room and living room, open beam cellutex ceiling. Door lintels and bay window surround carved and scrolled; short curving flush brackets. Open hearth stone fireplace with hewn timber as mantel. Interior door panels of knotty pine, wood pegs. Bedrooms on main level and upstairs interior finished in plywood with molding trim, painted. Some exterior material replacement, aluminum awnings and some aluminum casements added.

R6-10-03-DE 5

Butte Falls Ranger Station, Ranger's Residence Garage: Rectangular, wood frame, poured concrete foundation, wood shingled medium gable roof, two vehicle capacity. Horizontal clapboard exterior, vertical boards, plain ends, chamfered battens every other board on gable ends. Two vertical lift wood panel doors on west gable end, single leaf wood panel entry off-set on north elevation. Sixlight sash windows. Single well-defined pine tree cut out, centered beneath roof apex, on east and west gable ends. 
Butte Falls Ranger District

R6-10-03-DE6

R6-10-03-DE7

R6-10-03-DE8

R6-10-03-DE9
Butte Falls Ranger Station, Equipment Warehouse 非200: 1936; Rectangular, 1story wood frame, poured concrete foundation, narrow cobblestone veneer (15"), wood shingled medium gable roof.

Horizontal clapboard exterior, vertical boards, rounded ends, on gable ends. Three chamfered beams (ridge pole and lintels) project slightly beyond plane of building. Six-light hinged wooden

casement windows. Concrete loading dock, side stairs, off-set on west (main)

elevation access single large slide opening door. Horizontal slide opening door offset on north gable end.

Butte Falls Ranger Station, Vehicle Storage, 非1504: 1938; Rectangular, 1story wood frame, poured concrete foundation, cobblestone veneer visible on three sides, wood shingled medium gable roof. Horizontal clapboard exterior, vertical boards, rounded ends, on gable ends, three chamfered beams project slightly from each gable (ridge pole and lintels). Sixlight sash windows. Four bays open on north elevation, fifth bay enclosed, with single leaf vertical board door centered. Single wel1-defined pine tree cut-out on each gable end, centered beneath peak of gable.

Butte Falls Ranger Station, Gas and $0 i 1$ House: Rectangular, wood frame, concrete foundation and slab, wood-shingled medium gable roof extending beyond anterior wall to form pump shelter, supported by two $4 \times 4$ posts. Horizontal clapboard exterior, including gable ends. Single horizontal slide opening door centered in anterior wall on west gable end. No decoration.

Butte Falls Ranger Station, Storage Shed: Rectangular, wood frame, poured concrete foundation, wood shingled medium gable roof. Horizontal clapboard exterior. Two-leaf hinged doors, west gable end. No decoration. Structure is detached, located at right angle to gas house. 
Butte Falls Ranger District

R6-10-03-DE10

Butte Falls Ranger Station, Incinerator:

Squared coursed rubble masonry structure approximately three feet high, three feet wide, with concrete surface, remnants of wire mesh adhering. Rectangular metal doors (12" x 24") cover openings of base on north and west sides. No longer in use. Upper parts missing.

R6-10-03-DE11 Stone Post and Rail Fence: Encloses compound across east end, Ranger's residence and garag e excluded. Massive stone posts of native lava rock, squared and coursed, alternately four feet in height and three feet in height, interspersed with two horizontal pole rails with low stone curving beneath, curving inward at former Ranger Station Office (\#2002), punctuated by semi-circular office access drive, and continuing beyond as before; isolated center section in front of office has been reduced to curb level; end past on north, bathressed, wooden plaque inset "U. S. Dept. of Agriculture-Forest Service-Butte Falls Ranger Station-Built by C.C.C. -Rogue River Camp-A.D. 1936", sign is routed with two very naturalistic pine trees flanking the initials "C.C.C."

R6-10-03-DE12 Lodgepole Guard Station, Cabin \#1014: Rectangular, 1-story wood frame, poured concrete foundation, wood shingled hipped gable roof, projecting center hipped gable porch supported by two peeled poles on west (main) facade, open concrete platform, two plain straight steps. Single brick interior chimney, centered, east slope of roof. Horizontal clapboard exterior, end boards. Six-over-one double-hung sash windows. Main entry, a single leaf French-type door. No decoration. No obvious structural or material alterations to exterior, except recent addition of metal chinney cap and spark arrester. 
R6-10-03-DE13 Lodgepole Guard Station, Barn 非405:

1933; Rectangular, wood-frame, threehorse stable, mudsills on concrete piers, wood shingled medium gable roof. Horizontal clapboard exterior, end boards, horizontal grooved siding on south (rear) elevation. Four bay structure, three open bays on north elevation access stalls, fourth bay on northwest corner enclosed for tack and feed storage. Nine-light sash windows on west gable end, single-leaf center door. Large slide opening door off-set on east gable end. No decoration. (Plan, design and execution very similar to Union Creek barn.)

R6-10-03-DE14 Lodgepole Guard Station, Large Shed 非1511:

1933; Rectangular, 1-story wood frame, stone foundation, wood-shingled hipped gable roof. Horizontal clapboard exterior, end boards, 'Square singlelight windows. Single-leaf door offset on south gable end. No decoration. Some material alteration on north gable end.

Imnaha Guard Station Cabin: 1939; Tshaped, 1-story wood frame, poured concrete foundation, wood shingled medium gable roof, off-set cross gable; stepped gable forms front (west) porch roof, supported by $10 \times 10$ squared timber posts with curving brackets, affixed; rear entry is covered by a small projecting gabled porch, enclosed. Single coursed rubble interior chimney straddles ridgeline of main gable, centered. Horizontal clapboard exterior to eaveline, vertical boards, corner notches, on all gable ends. Six-over-six double-hung sash windows, singly and in combinations with mullions. Single well-shaped pine tree symbol centered on single board beneath peak of roof on each gable end. No obvious structural or material alterations to exterior. In excellent condition. Cable-wrapped wood stave water tank on raised platform supported by post and beam constructed tower, adjacent to cabin. 
Butte Falls Ranger District

R6-10-03-DE16

Imnaha Guard Station Barn: Rectangular, 1-story, peeled pole construction, threehorse stable, mudsills on concrete piers, wood shingled medium gable roof. Wall shake exterior overall. Four bay structure, three open bays access stalls, fourth bay enclosed for tack and feed storage. Six and nine-light sash windows. Single leaf door with strap hinges off-set on gable end. No decoration. Exterior wall materials missing from several areas, structural members and interior sheathing exposed.

R6-10-03-DE17

Imnaha Guard Station, Shed: Rectangular, 1-story, wood frame, poured concrete foundation, wood shingled medium gable roof. Horizontal clapboard exterior, vertical boards, corner notches, on gable ends. Eight horizontal light sash windows. Large slide opening door offset main facade, single leaf door offset on east gable end. Slender elongated pine tree cut from single board centered below peak of roof on each gable end. No obvious structural or material alterations to exterior.

R6-10-03-DE-R1 Wickiup Meadows Shelter: Rectangular, Adirondack-type, peeled pole construction, split shake saltbox roof, comb ridge treatment, sills on rock piers. Long wall shake exterior, main facade open. Some roof materials deteriorated, damaged or missing. Appears to be structurally sound. 
Prospect Ranger District

R6-10-06-DE1

Mathews Guard Station Residence: 1932; Rectangular, 1-story wood frame, stone foundation, coursed, squared rubble with cobbles, split shake medium gable roof, with gabled hip on north forming covered porch, extending width of gable end, semi-enclosed by railing of horizontai narrow rounded shiplap, four straight stone steps access plank surface and center entry. Horizontal narrow rounded shiplap exterior, end boards. Four-over-four double-hung sash windows, and four-light hinged casements. No decoration.

R6-10-06-DE2

R6-10-06-DE3

Mathews Guard Station Garage: 1932;

Rectangular, wood frame, concrete foundation, split shake medium gable roof.

Horizontal narrow rounded shiplap exterior, end boards. Single entry off-set on north gable end, two-leaf hinged doors off-set on east elevation. No decoration.

Union Creek Ranger Station, Residence 非031: 1934; T-shaped, wood frame structure, high hipped roof, high intersecting gable, uncoursed lava rock foundation. Exterior sawn wood shingles, multi-light sash windows, covered porches. Exterior in very good condition, altered only by addition of shed roofed lean-to storage shed.

R6-10-06-DE4

Union Creek Ranger Station, Garage 非529: 1935; Rectangular, detached wood frame, high gable roof, exterior board and batten and wood shingles.

R6-10-06-DE5

Union Creek Ranger Station, Residence 非1032:

1940; Single story, L-shaped wood frame, lava rock foundation hipped gable roof with gabled hip on north end. Exterior, sawn horizontal clapboards and vertical board and batten, multi-light sash windows, covered porches, pine tree logos cut out on west gable end. Exterior in very good condition. Altered only by replacement of sash window with an aluminum casement. 
Prospect Raniger District

R6-10-06-DE6

R6-10-06-DE7

R6-10-06-DE8

R6-10-06-DE9

R6-10-06-DE10

R6-10-06-DE11
Union Creek Ranger Station, Garage \#1528: 1935; Rectangular, wood frame with high gable roof, exterior board and batten and wood shingles.

Union Creek Ranger Station, Residence \#1033: 1931; Single-story, T-shaped, wood frame, lava rock foundation, high gable roof 'with cross gable. Exterior wood shingles, multi-light sash windows. Remodeled interior and exterior, 1940 by CCC, converting use from office to residence. Pine tree logos on west and south gable ends and on west porch pediment. Exterior in good condition, no obvious alteration.

Union Creek Ranger Station, Garage \#1525:

1935; Attached, wood frame with gable roof, exterior half-round shiplapping. Divided internally with closed storage space. Very good condition, no obvious alteration.

Union Creek Ranger Station, Residence \#1035: 1927; Rectangular, single story, wood frame, cement block foundation, high gable roof, exterior narrow, rounded shiplap, multi-light sash windows. Formerly Hamaker Meadows Guard Station, was removed to present site in 1955. Lacking integrity of location, no obvious exterior alteration.

Union Creek Ranger Station, Horse Barn \#2413: 1936; Rectangular, peeled-pole frame on lava rock foundation high gable roof, exterior 1 × 8 wood lap siding butting to 1 x 4 corner trim. Three bays on east elevation open. Enclosed storage area on north end. Roof material and roof trim damaged on northwest corner, otherwise structurally and materially sound, unaltered.

Union Creek Ranger Station, Fire Equipment Shed \#2306: 1942; Rectangular, peeled-pole framing, exterior wood shakes and vertical board and batten, high gable roof, open length of south elevation. 
Prospect Ranger District

R6-10-06-DE11

R6-10-06-DE12

R6-10-06-DE13

R6-10-06-DE14

R6-10-06-DE15

R6-10-06-DE-RI
1962-63, wood shake roof replaced with corrugated metal. In very good condition.

Union Creek Ranger Station, Fire Warehouse \#2205: 1934; Rectangular, two-story, heavy timber construction on lava rock foundation, high gable roof with gabled and shed roofed dormers. Exterior wood shingles and vertical board and batten, multi-light sash windows, covered porch on south facade, pine tree logo on porch pediment. 1946, second story converted to residential apartments, outside stairs added. 1959, stairs, rebuilt, gabled porches added. 1962-63, wood shake roof replaced with corrugated metal, stairs covered with sloping metal roofs. Exterior of structure retains much of its architectural integrity despite alterations, in very good condition.

Union Creek Ranger Station, Light Plant House \#1602: 1942; 13 × 16 wood frame on lava rock foundation, high gable roof, exterior wood shingles and vertical board and batten. In very good condition, unaltered.

Union Creek Ranger Station, Gas and Lube Shed \#2564: 1935; Wood frame saltbox on lava rock foundation exterior wood shingles and vertical board and batten multi-light sash windows, recessed umbrage. In good condition, several windows boarded, otherwise unaltered.

Union Creek Ranger Station Garage: 1940; Rectangular wood frame with medium gable roof, exterior horizontal clapboard with $1 \times 4$ corner trim, multi-light sash windows. Vertical overhead door on south gable end may be recent alteration. Presently used for storage; the garage originally belonged to the District Ranger Office, demolished in 1976.

Union Creek Campground: 1934; Constructed on the site of early informal camping area, the formal public occupancy site ex- 
Prospect Ranger District

R6-10-06-DE-R1 tended along the north and south banks of Union Creek to its confluence with the Rogue River. Subsequently expanded, 23 campsites retain the spacious secluded character of Depression-era tent spaces, including heavy stone stoves. Pipe water system, with little to moderate site modification.

R6-10-06-DE-R2 Community Kitchen: 1935; Rectangular $(20 \times 30)$ heavy peeled-log construction on raised lava rock platform, high hipped roof, central stone chimney, four stoves, wet sink with drainboard, four half-log picnic tables. Railing of horizontal peeled logs with smaller vertical peeled uprights. Sugar pine shake roof replaced 1978, with like materials, end-nailed as original. Excellent condition.

R6-10-06-DE-R3 Registry Booth - Comfort Station: 1935; Rectangular post-on-sill construction of half-logs, originally bark-covered. 1956, a cement foundation was placed beneath structure. In very good condition, little altered.

R6-10-06-DE-R4 Community Bonfire Ring: 1934-35; Ring of cut and fitted basalt blocks, approximately six feet in diameter.

R6-10-06-DE-R5 Upper Rogue River Trail: 1936; Segment between Natural Bridge and Union Creek follows the east bank of the Rogue River.

R6-10-06-DE-R6 Natural Bridge Campground: ca. 1933-34; Extends along east bank of Rogue River above Natural Bridge at end of Forest Road 3106. Nine campsites retain spacious and secluded qualities of Depression-era tent spaces, with heavy stone stoves. Subsequently expanded, the campground shows little site modification.

R6-10-06-DE-R7 Community Bonfire Ring: Ring of small cut and fitted basalt blocks, approximately four feet in diameter. Stone is worn. 
Prospect Ranger District

R6-10-06-DE-R8

Stone Walk, Entrance Overlook: ca. 193334; Flagged stone walk over exposed basalt flow to entrance viewpoint. Three foot overlook fence of roughly cut and fitted basalt blocks. Flood damaged 1964, repaired, in good condition.

R6-10-06-DE-R9 Remnant - Stone Walk, Exit Overlook: ca. 1933-34; Heavily damaged in 1964 flooding, stone walk almost obliterated, not repaired. A low overlook fence of roughly cut and fitted basalt blocks above exit. Deteriorated.

R6-10-06-DE-R10 Farewe11 Bend Campground: 1933-34; A formal public occupancy site extending along the east bank of the Rogue River. Severely damaged by floods in December 1964, Farewel1 Bend has been rehabilitated and now exhibits a high degree of site modification.

R6-10-06-DE-R11 Winter Sports Area: 1935; Downhill ski slope, rope tow, and peeled-pole and shake warming shelter. Rope tow, shelter since dismantled. Area now used for snowplay.

R6-10-06-DE-R12 Winter Sports Area: 1935; Large, triangular open hearth stone fireplace from warming shelter remains.

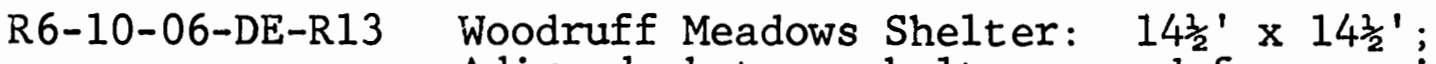
Adirondack-type shelter, wood frame using peeled poles, saltbox roof style, east elevation open, north and south gable ends and west elevation enclosed by long wall shakes, split shake roof material, comb ridge treatment. Structure is badly deteriorated, with structural damage apparent, exterior and roof materials missing. 
ROGUE RIVER NATIONAL FOREST

Medford Service Center

R6-10-SO-DEI

Medford Service Center, Road Crew Building \#2301: 1935; 36' x 95'; Rectangular, 1story wood frame post and truss construction, poured concrete foundation, woodshingled medium gable roof, eight bays in length, five bays open on west elevation $8 \times 8$ posts on concrete footing, one bayvertical lift door, enclosed office space, N. W. corner, off-set entry, gabled hood. Horizontal shiplap exterior, $1 \times 4$ and boards, vertical shiplap on west elevation of enclosed office north gable end to window level is sheet metal clad. Twelve-light single sash windows. iNo decoration. Exterior wall materials, west elevation, replaced.

R6-10-SO-DE2

Medford Service Center, Radio Shop \#2202: 1936; 36' x 95'; Rectangular, 1-story wood frame, poured concrete foundation, wood shingled gable roof, center gable on east (main) elevation. Center gable bay projects ca. two feet from plane of building, front wall of bay slightly recessed enclosed, projecting walls have squared, coursed rubble veneer at base, loading docks, with vertical lift door off-set in center gable, single leaf door off-set in center gable. Horizontal clapboard ( $1 \times 12$ ) exterior to eave line, end boards vertical boards, corner notched, on all gable ends. Three bays vehicle storage with vertical lift doors to south of center bay on east facade, enclosed office space to north, off-set single leaf door, projecting that roof covers raised platform, simple railing, side steps access office. Nine-light single sash windows, singly and in combinations with mullions. Single well-shaped pine tree cut out on center gable end, above nine-light window, below roof apex. No significant exterior material or structural alteration. 
Medford Service Center

R6-10-SO-DE3

Medford Service Center, Warehouse \#2203: 1935; 80' x 80'; Rectangular, two story window frame, poured concrete foundation and slab, wood-shingled two-sided mansard roof, medium hip, three elevated rectangular light bays, equidistant on flat roof surface. Vertical, grooved plywood siding exterior, end boards. Mullion windows of six and three divisions, each having sixteen lights. North (main) elevation has off-set single leaf door with gabled hood, two large double leaf vertical board slide opening doors and three recessed large vertical lift doors; south elevation has three large double-leaf vertical board slide opening doors and a smaller slide opening door off-set. No decoration. Exterior wall material formerly horizontal boards, end boards, now replaced with vertical plywood siding.

R6-10-SO-DE4

Medford Service Center, Vehicle Storage Shed \#2300: 1937; 50' $x$ 80'; Rectangular, 1-story wood frame, post and beam construction, poured concrete foundation, dirt floor, wood shingled medium gable roof, four bay structure, open on north and south elevations, supported by eight $10^{\prime}$ $x 12 '$ squared-timber posts on concrete footings, with short, heavy curving brackets, tapered, affixed. East and west gable ends, horizontal clapboard to eave line, vertical boards, corner notched on gable ends. Single graceful pine tree with narrow base cut from single center board immediately below roof apex on east and west gable ends. Exterior materials original on east end, horizontal clapboard replaced with horizontal vinyl siding on west gable end, appearance similar.

R6-10-SO-DE5

Medford Service Center, Gas House \#2500: 1936; $16^{\prime} \times 30^{\prime}$; Rectangular, 1-story wood frame, poured concrete high foundation, coursed squared-rubble veneer; woodshingled medium hip roof, center portion of south slope extends to form porch cover, supported by three squared-timber posts on each corner, short, heavy curving 
Medford Service Center

R6-10-SO-DE5

brackets, affixed. Center single-leaf vertical board door on south elevation; plank and timber loading dock, side steps extend across north elevation, doubleleaf slide opening doors. Grooved vertical siding exterior. Mullion windows, two divisions of six vertical lights each. No decoration. Original IxI2 horizontal clapboards replaced with vertical plywood siding. Pump Island, opposite north elevation, slightly raised concrete platform, rectangular, covered, open, wood shingled medium gable roof, supported by two squared timber posts with short, heavy curving brackets, affixed, at each gable end enclosed by vertical boards, corner notched. No decoration. No obvious alteration. 
Gold Beach Ranger District

R6-11-03-DE2

Gold Beach Ranger Station, Ranger's Residence 非1005: 1936; 1584 sq. ft.;

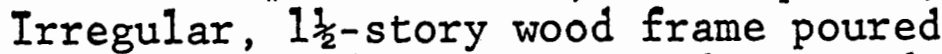
concrete foundation, coursed squared rubble veneer, basement, wood shingled medium gable roof, stepped intersecting off-set gables on south (main) elevation, with hipped porch roof off-set, covering stone veneered semi-enclosed entry, four straight plain steps ascend to flagstone platform; projecting gable on west elevation, stepped intersecting gable off-set on north elevation, shed-roof bay abuts main gable end. Exterior chimney, coursed, squared stone, random verticals, double arched cap, abuts west projecting gable, interior stone chimney, similar texture, single arched cap, off-set on west slope of main gable. Horizontal clapboard exterior, vertical boards, angular cut, battens on free-standing gable ends, plain vertical board and batten on main gable ends. Six-over-six. and one-over-one double-hung sash windows. Double leaf hinged garage doors centered lower level south off-set gable end, vertical lift garage door, centered, lower level north off-set gable end. Single elegant pine tree located at center of each free-standing gable end. Pine trees are cut from separate source board, affixed to wall material rather than cut from wall fabric. In excellent condition. No obvious structural alterations to exterior.

R6-11-03-DE7

Gold Beach Ranger Station, Warehouse 非201: $1936 ; 2170$ sq. ft. ground story;

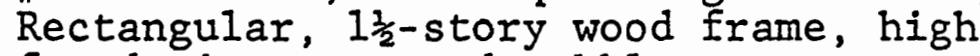
foundation, coursed rubble veneer, wood shingled saltbox roof, three gabled dormers equidistant on west slope of roof, gable dormer of similar proportion centered, east roof slope, flanked by larger gabled dormers approximating off-set gables, coursed rubble interior chimney, single arched cap, off-set on west roof slope. Horizontal clapboard exterior, vertical 
R6-11-03-DE7 board, angular cut, and battens on gable ends. Vertical boards cover the extent of the two off-set gabled dormers on the east elevation. Mullion windows of four and six divisions, the upper divisions having three lights, the lower six lights, muliion windows having three divisions of six vertical lights in upper story. Five bays in length, the second and fourth bays open as loading docks on west (main) facade. A single elegant pine tree, cut from separate material is affixed in the center of each dormer pediment, and beneath the peak of the roof on each gable end. No obvious exterior alteration. 
Illinois Valley Ranger District

R6-11-04-DE9

Cedar Guard Station 非019: 1933; 588 sq.

ft.; Rectangular, 1-story wood frame, cobblestone foundation, wood shingled medium gable roof, center porch gable north (main) facade, entry recessed almost enclosed by solid walls of porch, three straight stone steps access flagstone platform. Coursed cobblestone chimney centered, below ridgeline on south slope of roof. Exterior wall material is cedar bark, with verges and eaves boxed by quarter-round cedar logs, bark on. Six-over-six double-hung sash windows single and in pairs with mullions. No decoration. No apparent alteration to exterior.

R6-11-04-DE10

Cedar Guard Station, Garage 非318: 1936; $480 \mathrm{sq}$. ft.; Rectangular, wood frame, one vehicle capacity, wood shingled medium gable roof, center gable hood south elevation. Cedar bark exterior. Double leaf, hinged, diagonal board doors offset on east gable end. Laminated flush door, center south facade, with diagonal board and batten panel adjacent, indicates recent alteration. No decoration.

R6-11-04-DE1I

Store Gulch Guard Station 非1020: 1933 ; $320 \mathrm{sq}$. ft.; T-shaped, 1-story wood frame, poured concrete foundation, wood shingled medium gable roof with narrow center gable porch, semi-enclosed by solid porch wall, second gable abuts center of south wall forming a step rather than an intersection. Cedar bark exterior. Six-over-six double-hung sash windows. No decoration. No obvious exterior alteration. 
SISKIYOU NATIONAL FOREST

Powers Ranger District

R6-11-05-DE6

Ferris Ford Work Center, Cedar House

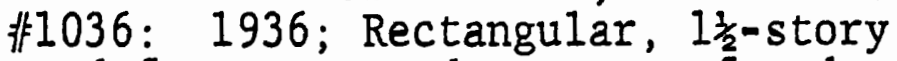
wood frame, poured concrete foundation, split shake high gable roof, off-set intersecting gable on east (main) facade, shed porch roof extends from lower elevation of main gable roof, single large gabled dormer centered on west (rear) slope of roof. Cedar bark exterior overall, horizontal pole delineates eave level on north, south and east gable ends. Six-over-six double-hung sash windows, singly and in pairs with mullions. Upper level windows are eight vertical light single sashes.

A gabled open breezeway off-centered, west elevation, split shake roof, attaches house to rectangular, wood frame single vehicle garage, having a poured concrete foundation, split shake high gable roof and cedar bark exterior with pole trim. Nine-light single sash windows. Breezeway covers center single-leaf door in east gable end of garage. No decoration. No obvious exterior alteration. In excellent condition. 
SIUSLAW NATIONAL FOREST

Mapleton Ranger District

R6-12-02-DE1

Mapleton Ranger Station Compound, Ranger's Residence 非021: Rectangular, $1 \frac{1}{2}$-story wood frame, poured concrete foundation, basement, hipped gable roof, hipped gable porch off-set on south gable end (main) facade, hipped gable center bag, upper story, east elevation, gabled hood, off-set, north gable end. Verges bracketed. Brick interior chimney, offset on west roof slope. Horizontal shiplap exterior, end boards. Mullion window with single large light surmounted by six transom lights and flanked by two double-hung six-over-one sashes, south gable end. Window treatment repeated in center bay, east elevation. Six-over-one double-hung sash windows, singly and in pairs with mullions. Porch entry raised, seven straight steps with simple railing ascend to planed lumber platform. No decoration. Composition shingle roof material.

R6-12-02-DE2

Mapleton Ranger Station Compound, Residence 非022: L-shaped, 1-story wood frame, poured concrete foundation, hipped roof with intersecting gable off-set, east elevation, projecting bay, off-set on east elevation. Hipped dormer, center west roof slope, gabled hood, center south elevation. Brick interior chimney at ridge junction. Wall shake exterior. Eight-over-one double-hung sash windows. Bay window projects from off-set east gable end, thirty lights surmounted by scrolled cornice and flanked by squaredtimber side trim incorporating chevron patterned brick. Decorated brick sill, continuous. Main entry is recessed, off-set in south elevation of east projecting gable, with semi-elliptical arch. Composition shingle roof material. 
SIUSLAW NATIONAL FOREST

Waldport Ranger District

R6-12-05-DE-RI Cape Perpetua, Stone Shelter, West Viewpoint: 1933; 15'x20'; Rectangular, stone structure coursed rubble, split shake saltbox roof. The north and south walls arch above roof in semi-elliptical shape, arching structural door openings with radiating voissoirs, north and south, semi-circular window openings adjacent, toward rear. East wall is entirely enclosed, west elevation is open. Flagstone floor extending to west as a terrace, enclosed by a solid stone railing which extends downward giving the appearance of a parapet from below. In excellent condition. No apparent alterations. 
UMPQUA NATIONAL FOREST

Cottage Grove Ranger District

R6-15-01-DE-RI Rujada Campground Registry Booth: 1934;

8 'x10'; Rectangular, post and beam construction using large diameter peeled logs and poles, flagstone platform, split shake gable roof. Four large log uprights, corner brackets, support roof, all elevations and gable ends open. A single large log section, one surface hewn, rests on two fitted log uprights as register base. Two half-log benches occupy the center portion of the floor back to back. In good condition. Heavy growth of mosses and ferns on roof. 
UMPQUA NATIONAL FOREST

Tiller Ranger District

R6-15-02-DE1

Tiller Ranger Station, Residence 非1056:

1936; 12.5x9m; Rectangular, 1-story wood frame, poured concrete foundation, coursed rubble veneer, wood shingled gabled hip roof, off-set gable on east (main) elevation, main entry off-set, recessed on gable end, supported by a squared-timber post with short, slender curving brackets affixed, three stone side steps access open flagstone platform, shed-roofed hood off-set on west elevation. Coursed rubble exterior chimney, center north elevation. Wood shingle exterior, vertical boards, ends rounded, on gable end and on gablets. Six-over-six double-hung sash windows, singly and in combinations with mullions, flanked by decorative shutters each having a smal1, complex pine tree cut out slightly above center. Similar, slightly larger pine trees cut out on gable end and on each gablet. In excellent condition. No obvious exterior alterations.

R6-15-02-DE2

Tiller Ranger Station, Residence 非1058: $1936 ; 7.5 \times 9 \mathrm{~m} ; \mathrm{T}$-shaped, $1 \frac{1}{2}$-story wood frame, poured concrete foundation, coursed rubble veneer, wood shingled high gable roof, off-set intersecting cross gabled hip, main entry, off-set recessed in north projecting cross gable end, supported by squared-timber post, short, slightly curving brackets affixed, three straight stone steps access open flagstone platform, shed roofed hood above off-set rear entry. Coursed rubble masonry exterior chimney, off-set on east elevation. Wood shingled exterior, vertical boards, ends rounded, on gable ends and gablets. Sixover-six double-hung sash windows, singly and in combinations with mullions, flanked by decorative shutters, each having a small, complex pine tree cut out slightly above center. Similar, slightly larger pine tree cut-out centered on north-facing gablet. No obvious exterior alterations. 
UMPQUA NATIONAL FOREST

Glide Ranger District

R6-15-04-DE1 Glide Ranger Station, Old Office 非1084:

1938; T-shaped, 1-story wood frame, poured concrete foundation, wood shingled medium gable roof, center intersecting gable, east elevation, center porch gable, west elevation (main) facade, supported by two squared-timber posts with long curving inset timber brackets, open flagstone platform approached by three wide straight stone steps. Interior chimney off-set on east roof slope. Horizontal clapboard exterior, vertical boards, battens every other board on all gable ends. Eight-over-eight doublehung sash windows, each flanked by decorative shutters having hand forged strap hinges and single large wellshaped pine tree cut-out centered. Large graceful pine trees centered on each gable end, a rectilinear arrangement of three on the porch gable pediment, a large center tree extending almost the height of the pediment board flanked by two smaller trees of complex design. No obvious exterior alteration. 
UMPQUA NATIONAL FOREST

Steamboat Ranger District

R6-15-05-DE-E1 Mott Bridge: 1935; 260 feet long;

Vehicle bridge. Arched truss construction using treated $12 \times 12$ timbers with poured concrete abutments and embankments. A single arch spans the North Umpqua River, single lane; formerly having a plank deck, since replaced by metal grid surface. Three horizontal board railing utilizes $2 \times 4^{\prime} \mathrm{s}$. Bronze dedication plaque at north end of bridge reads "Mott Bridge - Built in 1935 - By Civilian Conservation Corps Dedicated to the Memory of Major Lawrence Mott, who camped on the bank of the North Umpqua River for several years and who died here in May 1931." Mott Bridge is the only surviving vehicular bridge of its type in Pacific Northwest Region. 
Bear-Sleds Ranger District

R6-16-02-DE1

Wallowa Ranger Station Work Center

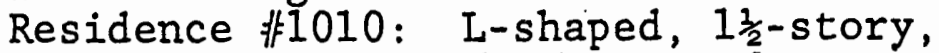
wood-framed, poured concrete foundation, wood-shingled medium gable roof. Offset, intersecting gable, hipped-roof dormer on. rear slope. Exterior brick chimney, stretcher bond, west elevation, coursed field-stone chimney on south roof slope. Front wall recessed, extended roof slope forms porch extending width of north facade, open, supported by paired squared-timber posts with affixed curving brackets, porch platform faced with coursed, squared-rubble stone. Horizontal clapboard exterior, vertical boards, angular cut, battens every other board. Six-over-six double-hung sash windows singly or in combinations with mullions. Single, well-shaped pine tree logo, just above center on each gable end. Storm windows and doors. No obvious structural exterior alteration.

R6-16-02-DE2

Wallowa Ranger Station Work Center Office

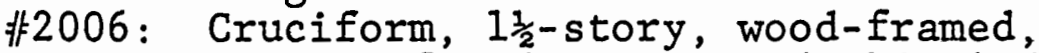
poured concrete foundation, wood-shingled medium gable roof with cross gable. Single stretcher bond brick chimney offset on south cross-gable. Horizontal clapboard exterior vertical board, angular cut, with battens every other board on each gable end. Six-over-six double-hung sash windows singly or in combinations with mullions. Recessed entry off-set in north cross-gable end. Shaped and decorated lintel, flanked by squared-timbers and affixed curving brackets. Similar scroll design on off-set south cross-gable entrance (rear). Porches have flagstone surfaces, platforms faded with coursed rubble stone masonry. A single welldescribed pine tree cutout centered on north off-set gable end; decorative shutters with simple pine tree design cutout on lower floor windows. No apparent structural alteration. 
R6-16-02-DE3

R6-16-02-DE4
Wallowa Ranger Station Work Center Gas House 非5026: Small, rectangular, woodframe, poured concrete foundation, woodshingled medium gable roof. Front wall recessed, open porch supported by squaredtimbers. Short, low loading door extends from north elevation. Horizontal clapboard exterior, vertical boards, angular cut, battens every other board. Single simple pine tree logo centered on each gable end. No apparent exterior alterations.

Wallowa Ranger Station Work Center Ware-

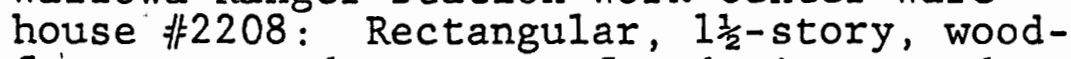
frame, poured concrete foundation, woodshingled medium gable roof with center gable on west (main) facade. Single stretcher bond brick chimney off-set on west slope of roof. Center gable forms porch roof for loading dock, supported by squared-timber posts in combinations of three with short curving inset brackets. Horizontal clapboard exterior, vertical boards, angular cut battens every other board on all gable ends. Single wellshaped pine tree logo centered on gable porch pediment; decorative board shutters with simple pine tree design cutout exterior alteration. 
WALLOWA-WHITMAN NATIONAL FOREST

Pine Ranger District

R6-16-07-DE1

Residence \#1038: 1938; 52' x 36'; Tshaped, 1-story, wood frame, low gable roof. Large coursed rubble exterior chimney (red lava) on east facade, coursed rubble chimney off-set on north slope of roof. Horizontal clapboard exterior, vertical boards with triangular corner cuts, battens every other board on gable ends. Bellcast extension of off-set gable roof forms porch, supported by squared-timber posts with plain, curved capitals. Extension of gablet on west end forms rear porch cover. Sixover-six double-hung sash windows, on north facing gable end, a inullion window with six-over-six double-hung sash in the center, flanked by a pair of four-overfour double-hung sashes, and surmounted by transom lights. Single, large wellshaped pine tree, cut outs on north and east gable ends, single pair of board shutters with simple pine tree cut outs. Roof material now textured metal, storm windows and doors. No obvious structural additions or alterations. Interior of knotty pine paneling, with exposed timbered beams and trusses routed in a measured rectilinear pattern. Open flat arch between living and dining rooms having chamfered, beveled beams, with curving fitted brackets. Fireplace of coursed, squared rubble stone, having a handchiseled stone pine tree in place of cartouche.

R6-16-07-DE2

Garage \#1518: ca. 1938; 28' x 20'; Rectangular, wood frame, saltbox, concrete foundation. Horizontal clapboard exterior, vertical boards with triangular corner cuts on gable ends. Appears to have enclosed storage, one vehicle capacity. Nine-light single sash windows. Garage door now vertical overhead 1ift. Three equal-sized well-defined pine tree cut outs in rectilinear arrangement on each gable end. 
Pine Ranger District

R6-16-07-DE3

Residence \#1039: 1939; 46' x 24'; Rectangular, 1-story, wood framed, concrete foundation, low gable roof with off-set projecting gable roofed porch. Horizontal clapboard exterior, vertical boards with battens every other board. Windows eightover-twelve double-hung sashes and sixover-six double-hung sashes. A single well-shaped pine tree cut out on south gable end, a single shutter with simple pine tree cut out. Roof material now textured metal, storm windows and doors.

R6-16-07-DE4

Garage \#1519: ca. 1938; 20' x 20'; Square, wood framed, concrete foundation, low gable roof. Two vehicle capacity. Horizontal clapboard exterior, vertical boards with angled lower edges to produce scalloped effect overall, battens every other board. Single large vigorous pine tree cut out on each gable end, the tip of each meeting the peak of the roof. Garage doors are now vertical overhead lift.

R6-16-07-DE5

Machine Storage \#23046: ca. 1938; 54' x $50^{\prime}$; Rectangular, 2-story, wood frame, concrete foundation, medium gable roof. Horizontal clapboard exterior, vertical boards on gable ends. Three bays with slide opening doors. Mullion windows having nine-light single sashes in combinations. Three complex pine tree cut outs grouped in rectilinear pattern, the center larger than the two flanking, on each gable end. Roof material of corrugated sheet metal.

R6-16-07-DE6

Gas House \#25066: ca. 1938; 17' x 18'; Rectangular, wood framed, concrete foundation, saltbox, with recessed, partly enclosed umbrage to shelter gas pumps. Horizontal clapboard exterior, corner trim, vertical boards with triangular corner trim, vertical boards with triangular corner cuts on gable ends. Nine-light single sash windows. Plank and timber loading dock on east gable end. Board shutters with simple pine tree cut outs. Roof material now textured metal. 
Pine Ranger District

R6-16-07-DE7

Warehouse 非2205: ca. 1938; 52'x35'; L-shaped, wood framed, concrete foundation, wood shingled low gable roof with off-set gable on south. Coursed rubble chimney off-set on west slope of roof. Horizontal clapboard exterior, vertical boards with triangular corner cuts on gable ends. Eight-over-eight doublehung sash and sixteen-light single sash windows. Raised, recessed loading dock with random rubbie stone facing. Hand chiseled, high relief, a rough pine tree flanked by characters "U.S. - F.S." in center of dock facing just above ground level. Structure is in need of paint. No obvious exterior additions or alterations.

R6-16-07-DE8

Barn 非407: ca. 1938; 42'x32'; T-shaped, $1 \frac{1}{2}-$ story, wood framed, wood shingled low gable roof with projecting center gable. Horizontal clapboard exterior, vertical boards on all elevations above first story level. Hay loft door, upper level on gable end, vertical board slide opening door, off center main facade. Six-light single sash windows, singly or in combinations. Louvered ventilators on each gable end. No decoration. Structure is in need of paint. No obvious exterior additions or alterations. 
Union Ranger District

R6-16-08-DE2 Union Ranger Station Compound; Office 非2004: 1938; Cruciform, wood frame, wood shingled low gable roof with center cross gable. Single coursed rubble chimney offset on rear roof slope. Horizontal clapboard exterior, corner trim, vertical board with prominent battens on gable ends and along one longitudinal wall under the eaveline approximately 24 inches vertical dimensions. Main entrance recessed under center gable to form porch, flagstone platform. Six-over-six double-hung sashes and six-light horizontal single sash windows. No decoration. Addition to rear of structure, 1958, compatible design and materials. Formerly had shutters with simple pine tree logo. Now used as bunkhouse.

R6-16-08-DE3

Union Ranger Station, Ranger's Residence 非1938: L-shaped, 1-story, wood frame, poured concrete foundation with rock veneer, wood shingled low gable roof. Two coursed rubble chimneys off-set on rear roof slope. Horizontal clapboard exterior, vertical board and batten on gable ends. Recessed, open verandah with flagstone patio on northeast facade, two leaf, 10 vertical light french doors access. Enclosed gable roofed porch on northwest gable end, rear entrance. Six-over-six double-hung sash windows. Decorative shutters with simple pine tree logo. No obvious. structural additions or alterations.

R6-16-08-DE4

Union Ranger Station, Ranger's Residence Garage 非1525: 1938; Rectangular, wood frame, poured concrete foundation with uncoursed rubble veneer, wood shingled low gable roof. Horizontal clapboard exterior, vertical board and batten on gable ends. Two vehicle capacity. Two large vertical board slide opening doors, north facade. Vertical board door on N.E. gable end. No decoration. No obvious exterior alteration. 
Union Ranger District

R6-16-08-DE5

Union Ranger Station, Guard's Residence 非 045: 1938; L-shaped, 1-story, wood frame, poured concrete foundation with random rubble veneer, wood shingled low gable roof. Coursed rubble chimney, offset on north slope of roof. Horixontal clapboard exterior, corner trim, vertical board with prominent batten every other board on gable ends. Shed roof covers flagged front entry. Recessed open verandah with flagstone patio on south elevation. Six-over-six double-hung sashes singly and in combinations with mullions. No decoration. No obvious exterior addition or alteration. Handforged knocker on front door. Vertical board "false" door on N.E. facade of main entry.

R6-16-08-DE6

Union Ranger Station, Guard's Residence Garage 非526: 1938; Rectangular, wood frame, wood shingled saltbox on concrete foundation with random rubble veneer. Horizontal clapboard exterior, vertical board with battens every other board on gable ends. Two vehicle capacity. Two vertical board slide opening doors. Nine-light single sash windows. No decoration. No obvious exterior alteration.

R6-16-08-DE7

Union Ranger Station, Gas House 非25076: 1938; Rectangular, wood frame, wood shingled saltbox on concrete foundation with random rubble veneer. Horizontal clapboard exterior, vertical board with battens every other board on gable ends. Recessed, partially enclosed umbrage houses gas pumps. Plank and timber loading dock on southeast elevation. Nine-light single sash windows.

Decorative shutters with simple pine tree logo. No obvious exterior alterations. 
Union Ranger District

R6-16-08-DE8

Union Ranger Station, Warehouse \#2206:

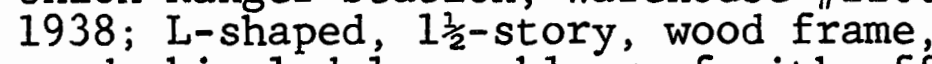
wood shingled low gable roof with offset intersecting gable on north end. Random rubble chimney off-set on rear slope of roof. Horizontal clapboard exterior, vertical boards on gable ends. Recessed loading dock with coursed rubbie facing, runs width of main facade, supported by pairs of squared-timber posts. Eight-over-eight double-hung sash windows. No decoration. iNo obvious exterior alterations.

R6-16-08-DE9

Union Ranger Station, Machine Shed

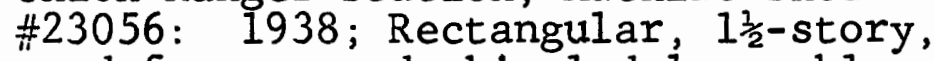
wood frame, wood shingled low gable roof. Horizontal clapboard exterior, vertical boards on gable ends. Three bays with double, vertical board sliding doors, flanked by squared-timber posts on threefoot concrete piers. Nine-light single sash windows in combinations with mullions. No decoration. No obvious exterior alteration. 
Unity Ranger District

R6-16-09-DE1

Unity Ranger Station, Residence 非501: L-shaped, 1-story, wood-frame, bellcast gable roof, wood-shingled, gabled hip on east end; cut-and-fitted, coursed red lava stone exterior chimney, off center on west elevation; horizontal clapboard exterior with plain vertical board and batten on all gable ends. Main roof extends to form porches on north (main) and east elevations, supported by combinations of squared-timber posts. Windows are sixover-six double-hung sashes singly with a mullion window on the north (main) facade having a six-over-six double-hung sash flanked by a pair of four-over-four double-hung sashes and surmounted by transom lights. Particularly graceful single pine tree logos cut out of two vertical boards centered on north and west gable ends. No apparent exterior alterations. In very good condition.

R6-16-09-DE2

Unity Ranger Station, Residence 非1052:

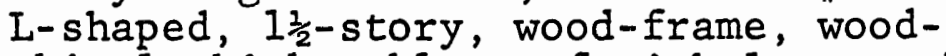
shingle high gable roof with large gable roofed dormer on south (rear) slope, major off-set gable on N.E. corner, with shed roofed porch adjacent on north (main) elevation. Porch roof supported by round peeled log posts. Cement chimney off center, north slope, brick chimney off center, south slope. Horizontal clapboard exterior with wood corner trim, vertical boards ends rounded, on all gable ends. Six-over-six doublehung sash windows singly and in combinations with mullions. Particularly graceful single pine tree logos cut out of two vertical boards centered just below peak on north, east and west gable ends. No apparent exterior alterations. In very good condition. 
R6-16-09-DE3

R6-16-09-DE4

R6-16-09-DE5
Unity Ranger Station, Warehouse 非207: T-shaped, wood-frame, wood-shingled medium gable roof with projecting major gable off center (N.E.); red lava stone chimney off center on south roof slope; raised, rock faced porch extends along north facade to off-set gable, building front recessed, main roof slope extends to form porch roof which is supported by squared-timber posts. Horizontal clapboard exterior with vertical board and batten on gable ends. Windows are eightand twelve-light single sashes with mullions. Single pine tree logo cut out on off-set gable end. Gable roofed storage area on east end may be an addition, although structurally and materialiy well matched. Very good condition.

Unity Ranger Station, Bunkhouse 非1306:

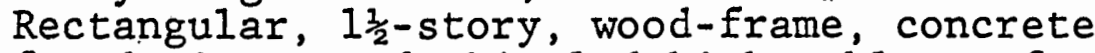
foundation, wood-shingled high gable roof with two large gable roofed dormers on front slope; two cement chimneys straddle ridgeline. Horizontal clapboard exterior with rounded vertical boards on gable ends. Six-over-six double-hung sash windows. Single graceful pine tree logos cut out just below peak on east and west gable ends. Six peeled pole purlins and ridge pole project at gable ends with peeled pole end joist as fascia. Effect repeated on dormers.

Antlers Guard Station, Residence 非1053:

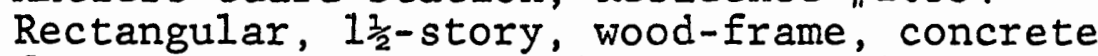
foundation, wood-shingled high gable roof. Horizontal shiplap exterior with wood corner trim. Six-over-six double-hung sash windows. Gabled porch roof, supported by $4 \times 4$ posts, off center on both east and west gable ends, gable pediment, horizontal shiplap. No decoration. No obvious exterior alteration. Well maintained. 
Unity Ranger District

R6-16-09-DE6

Antlers Guard Station, Garage 非1502:

Rectangular, wood frame, wood shingled high gable roof. Horizontal shiplap exterior, wood corner trim. Four-light horizontal single sash windows. Large, reinforced vertical board sliding door, off center on north gable end. Probable enclosed storage. Well maintained. No decoration. 
WENATCHEE NATIONAL FOREST

Entiat Ranger District

R6-17-05-DE1

Steliko Residence \#1162: 1935-38; T-

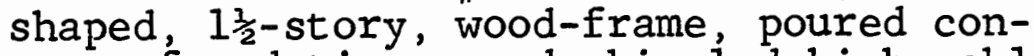
crete foundation, wood shingled high gable roof with center gable on east elevation. Horizontal shiplap exteior, end boards. Six-over-six double-hung sash windows, singly and in combinations with mullions. Shed-roofed open porch, north (main) facade. No decoration. Addition of semienclosed screened end porch extends width of south gable end.

R6-17-05-DE2

Steliko Residence \#1163: 1938; Rectangu-

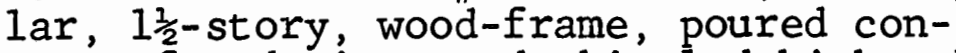
crete foundation wood-shingled high gable roof with off-set main gable on north (main) facade, large gable-roofed dormer, south slope of roof. Stretcher bond brick exterior chimney on west elevation. Horizontal shiplap exterior, end boards. Six-over-one double-hung sash windows, singly and in combinations with mullions. Hipped-roof hood above main and rear entrances. No decoration. No apparent exterior alteration.

R6-17-05-DE3

Steliko Warehouse \#2256: 1937; Rectangu-

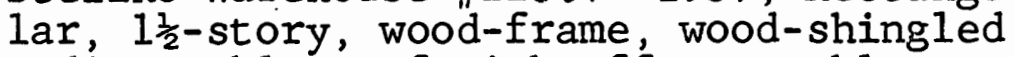
medium gable roof with off-set gable on north (main) facade, shed-roof extends from slope of main gable to form porch above loading dock, supported by heavy squared-timber posts with curved brackets, affixed. Loading dock is faced with coursed rubble stone. Horizontal clapboard exterior, vertical boards, battens every other board on all gable ends. ivine-light sash windows. No decoration. Concrete side steps added to west end of loading dock; no other apparent exterior alteration. 
Entiat Ranger District

R6-17-05-DE4

Steliko Barn 非457: 1937-38; Large, rectangular wood-frame, wood-shingled medium gable roof with three gabled dormers set immediately above eaveline on west elevation, enclosing nine-light sash windows. Horizontal clapboard exterior, vertical board, battens every other board on gable ends. Center, slide-opening doors on north and south gable ends, two-leaf hinged hay door on south gable end. No decoration. No obvious exterior alteration. 
Naches Ranger District

R6-17-08-DE1 Naches Flat Ranger's Residence 非1020: 1924; $31^{\prime} 9^{\prime \prime} \times 25^{\prime} 4^{\prime \prime}$; Rectangular, $1 \frac{3}{2}-$ story, wood-framed, poured concrete foundation, split-shake high gable roof with small center gable projecting on south (main) facade to form semienclosed porch. Horizontal rounded shiplap exterior, end boards. Six-overone double-hung sash windows, singly or in combination with mullions. No decoration. Attached to garage 非 1521 by enclosed $18^{\prime} \times 12$ ' breezeway, added to dwelling when garage built, 1933.

$\mathrm{R} 6-17-08-\mathrm{DE} 2$

Ranger's Garage and Woodshed 非1521: 1933; 31'x18'; Rectangular, wood-frame, split-shake medium gable roof. Horizontal rounded shiplap exterior, end boards. Wood-shingled, shed-roofed lean-to appended to west elevation of garage, for wood storage. No decoration. Vertical lift overhead garage door may be more recent alteration.

R6-17-08-DE3

Naches Flat, Assistant Ranger's Residence 非021: 1933; 33'4" x 27'; Rectangular, $1 \frac{1}{2}$-story, wood-frame, poured concrete foundation, wood-shingled high gable roof, single gable-roofed dormer off-set on south slope of roof, with projecting off-set gable on north (rear) elevation end, gable-roofed porch off-set on south (main) facade, supported by two sets of three heavy, squared-timber posts with short, heavy curved brackets, affixed. Vertical board, battens every other board exterior, narrow corner trim, horizontal clapboard on all gable ends. Six-overone double-hung sash windows, singly or in combination with mullions. No decoration. No obvious exterior alteration. 
R6-17-08-DE4

R6-17-08-DE 5

R6-17-08-DE6

R6-17-08-DE7
Clerks House 非1023: 32'6" x 20'6";

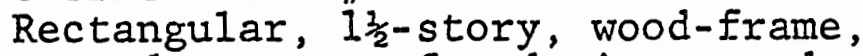
poured concrete foundation, woodshingled high gable roof with off-set gable porches, north and south (main) elevations. Horizontal shiplap exterior, end boards, including porch railings and gable pediments. Six-over-one doublehung sash windows, singly and in combinations with mullions. No decoration. No obvious exterior alterations.

Packer's Cabin 非1028 (Bunkhouse 非): 1936; 16.4' x 29.5'; Rectangular, 1-story, wood-frame, poured concrete foundation, wood-shingled high gable roof with gabled hood off-set on north (main) facade. Horizontal narrow, rounded shiplap exterior, end boards. Nine-light sash windows. No decorations. Two sash windows replaced with aluminum casements.

Assistant Firemen's Cabin 非1029 (Bunkhouse 非): $1933 ; 35.3^{\prime}$ x 16.4'; Rectangular, 1-story, wood-frame, poured concrete foundation, wood-shingled high gable roof, large enclosed gable, north gable end, small gable porch, south (main) facade. Horizontal, narrow rounded shiplap exterior, end boards. Six-oversix double-hung sash windows. Single coursed, squared-rubble stone chimney off-set on east roof slope. No decoration. No obvious exterior alteration.

Packer's Garage 非526: 1934; 18.2' x 36.2'; Rectangular, wood-frame, poured concrete foundation, wood-shingled medium gable roof. Horizontal shiplap exterior, end boards. Two large reinforced vertical board slide opening doors on east elevation off-center, north and south gable ends, structural door openings, describe one-half elongated octagon. No decoration. Door opening on east gable end partially enclosed. 
Naches Ranger District

R6-17-08-DE8

Firemen's Cabin 非120 (Bunkhouse 非6):

1933; 41.4' $x$ 16.4'; T-shaped, wood-frame; poured concrete foundation; wood-shingled high gable roof with cross gable on west, open gabled porch extends across east gable end. Horizontal clapboard exterior, end boards. Single, coursed, squaredrubble chimney straddles ridgeline, center. Six-over-one double-hung sash windows, singly and in combinations with mullions. No decoration. No obvious exterior alteration.

R6-17-08-DE9

R6-17-08-DE10

Fireman's Garage and Woodshed 非1527: 1937 ; $16.3^{\prime} \times 18.3^{\prime}$; Rectangular, wood-frame, poured concrete foundation, wood-shingled high gable roof. Horizontal shiplap exterior, end boards. Two single leaf Ix2 vertical shiplap, reinforced, slide opening doors on north gable end. Interior divided. No decoration. No visible alterations.

Prevention Assistant's Cabin 非1320: 1935; $30.3^{\prime} \times 22.3^{\prime}$; Rectangular, wood-frame, poured concrete foundation, wood-shingled medium gable roof, center gable-roofed porch, north gable end. Single, coursed, squared-rubble chimney, straddling ridgeline, center. Six-light sash windows, horizontal and vertical, pivot opening. No decoration. No apparent exterior alteration.

R6-17-08-DE1I

Naches Ranger Station Garage 非1520: $56.6^{\prime} \times 26.6^{\prime}$; Rectangular, wood-frame, poured concrete foundation, woodshingled high gable roof. Horizontal clapboard exterior; end boards. Vehicle storage capacity, five bays, siideopening doors, $1 \times 2$ vertical shiplap, reinforced. Square, single pane wood casement windows. No decoration. No apparent exterior alteration. 
Naches Ranger District

R6-17-08-DE12

Naches Ranger Station Machine Shop \#2111:

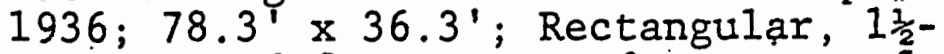
story, wood-frame, poured concrete foundation, wood-shingled high gable roof, shedroofed lean-tos east and west ends of south elevation. Horizontal shiplap exterior, end boards. Four pairs of single-leaf, $1 \times 2$ vertical shiplap, reinforced slide-opening doors on north (main) facade. Each leaf has horizontal six-light fixed casement window off-center. Singleleaf two panel wood door, center north facade. Twelve-light sash windows, singly or in combinations without mullions. No decoration. Lean-tos on real elevation may be later additions, but compatible in structural design and materials.

R6-17-08-DE13

Naches Fire Tool House and Garage 非2220 (FR\&T Building): 1933; 78.3' $\times 32.3^{\prime}$;

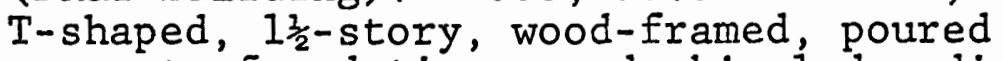
concrete foundation, wood-shingled medium gable roof with cross gable on north. Horizontal shiplap exterior, end boards. Twelve and six-light sash windows in combinations with mullions. No decoration. No apparent exterior alteration.

R6-17-08-DE14 Naches Ranger Station Freight Depot 非221 (storage building): 1935; 16.3' $\times 64.4^{\prime}$; Rectangular, 1-story, wood-frame, poured concrete foundation, wood-shingled stepped gable roof with center gable porch on main gable segment. Horizontal shiplap exterior, end boards. Concrete loading dock with single board railing under center porch gable. Wood-shingled shed porch roof extends from left of center porch gable. No decoration. Aluminum casement windows replace wood-sash windows. 
Naches Ranger District

R6-17-08-DE15

Naches Ranger Station Equipment Shelter ;2321: 1934; 24.3! x 110.3'; Rectangular, $1 \frac{1}{2}$-story, wood-frame, poured concrete foundation, wood-shingled high gable roof. Horizontal shiplap exterior, end boards. Twelve-light sash windows equidistant on west (rear) elevation. East (main) open vehicle storage, six bays, four bays enclosed with large, reinforced vertical board slide opening doors. No decoration. No structural alteration, exterior.

R6-17-08-DE16

R6-17-08-DE17

Naches Ranger Station Barn \#2420: 1923; $20.3^{\prime} \times 46.3^{\prime}$; Rectangular, 2-story, woodframe, split-shake and wood shingle bellcast gambrel roof with wood-shingled high gable roof extension, east end, gabled cupola, center gambrel ridge. Horizontal shiplap exterior, end boards. Four, nine and twelve-light sash windows. Slightly off-center single leaf door, west gable end, horizontal shiplap, contrasted reinforceinent, iron strap hinges; off-set in. center level, west end, single leaf door of diagonal shiplap, contrasted frame, iron strap hinges. No decoration. In excellent condition, unusual design.

Naches Ranger Station Gas and Oil House \#2520: 1934; 24' × 16.2'; Rectangular, wood-frame, poured concrete foundation, wood-shingled high gable roof. Front wall, south gable end, recessed, main roofiline extends to form porch, supported by two squared-timber brackets. Vertical shiplap exterior, end boards. Nine-1ight sash windows with mullions. Diagonal boards form triangular patterns, all facades. No apparent exterior alteration.

R6-17-03-DE18

Powder House \#2625: 1934; 11'6" x 9'6"; Rectangular, reinforced concrete structure, low hip roof, single reinforced steel door, east (main) facade. Built into slope. No decoration. No alteration. 
Naches Ranger District

R6-17-08-DE19

$R 6-17-08-D E 20$

$\mathrm{R} 6-17-08-\mathrm{DE} 21$

R6-17-08-DE-RI
Cap House 非624: 1936; 4'4" x 4'4"; Square, reinforced concrete structure, low hip roof, single reinforced steel door, built into slope. No decoration. No alteration.

American Forks Guard Station: 1930-31;

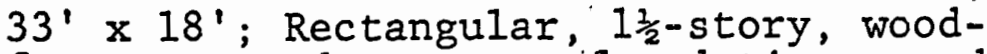
frame, poured concrete foundation, random rubble veneer, split-shake high gable roof, gabled hood, center south (main) facade. Wall shake exterior, vertical board and batten all gable ends. Coursed, squared-rubble chimney, center east roof slope. Six-over-one double-hung sash windows. No decoration. Door opening on east elevation boarded over.

American Forks Guard Station Garage and Woodshed: 1934; 18'6" x 16'6"; Rectangular, wood-frame, poured concrete foundation, split-shake high gable roof. Wall shake exterior, vertical board and batten on gable ends. Single large, reinforced vertical board slide opening door, offcenter north gable end. Interior divided. No decoration. No obvious alteration.

Sawmill Flats Community Kitchen: 1935-36; $23^{\prime} \times 17^{\prime}$; Rectangular, peeled $\log$ and pole construction, poured concrete platform, split shake high gable roof, pole ridge treatment. Six large log posts, each with two round brackets, two-pole railing, split shakes on gable ends. Large, coursed rubble stone chimney on east elevation, not enclosed with pole railing. Two side stoves, central openhearth fireplace. Half-round log bench with half-log back-rest and peeled-pole arm rests on horizontal log bases, to right of west side entrance. In very good condition; some gable end wall-shakes damaged. 
Naches Ranger District

R6-17-08-DE-R2 Boulder Cave Community Kitchen: 1936;

$23^{\prime} \times 27^{\prime}$; Rectangular, peeled $\log$ and pole construction, poured concrete platform, split-shake high gable roof. Six large log posts of approximately equal diameter, each with two round brackets, two pole railing, split wall shakes on gable ends. Large coursed rubble chimney on west elevation, not enclosed with pole railing. Two side stoves, central open-hearth fireplace. In excellent condition. Virtually identical to Sawmill Fiats Community Kitchen, floor plan reversed. 
WENATCHEE NATIONAL FOREST

Tieton Ranger District

R6-17-09-DEI

Residence \#1050: 1933-37; Rectangular, wood-framed, wood-shake medium gable roof, off-set gable north (main) facade, center gable south (rear) elevation, single hipped-roofed dormer off-set on south slope of roof. Exterior coursed rubble stone chimney, west gable end; coursed rubble inside end chimney, straddles east ridgeline. Horizontal clapboard exterior, vertical board and batten on gable ends; coursed rubble stone faces the off-set gable on the north facade to the eave line, faces or forms the foundation, faces the center gable on the rear facade, forming a bay extending the height of the ground level. Six-over-six double-hung sashes, singly and in combination with mullions, one twenty-light single sash window. Decorative shutters, vertical boards with contrasting reversed-z reinforcement. Gable end of south center gable is framed with heavy squared timbers, with carved scroll design on lower crossmember and hand-carved ovoid pendants suspended from vertical members. Four stone steps flanked by low, flaring solid railings of coursed rubble lead to center entrance, main facade. An open breezeway, split-shake gable roof supported by squared timbers with narrow curving affixed brackets connects to garage on east gable end. Flagstone patio, coursed rubble masonry walks, steps and railings below slope. No apparent exterior alteration.

R6-17-09-DE1A Root Cellar: Small, rectangular coursed rubble structure, built into natural slope. Wood-shingled medium gable roof, single center door. No decoration.

R6-17-09-DE2

Garage \#1550: 1933-37; Rectangular, woodframed, split-shake medium gable roof, attached by covered open breezeway to dwelling \#1050. Horizontal clapboard exterior, coursed rubble stone foundation below slope, decorative vertical board 
Tieton Ranger District

R6-17-09-DE2

R6-17-09-DE3

R6-17-09-DE4

R6-17-09-DE5 shutters with contrasting reversed-z reinforcement. Large slide-opening doors, north facade. No apparent exterior alteration.

Residence \#1051: 1933-37; Rectangular,

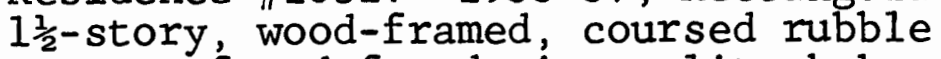
masonry faced foundation split-shake medium gable roof. Exterior stretcher bond brick chimney, west elevation, coursed rubble interior chimney, off-set, west slope of roof. Horizontal clapboard exterior, vertical board and batten on gable ends. Front wall recessed half the length of east facade to form porch, squared-timber posts with slender, curving brackets affixed, flagstone platform, open. Open, coursed rubble platforms, flagged surfaces on west and north elevations, covered. Six-over-six doublehung sash windows singly or in combinations with mullions. No decoration. No apparent exterior alteration.

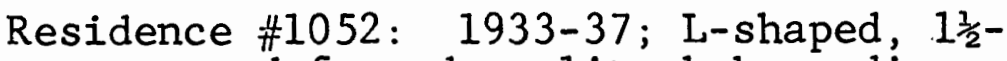
story, wood-framed, split-shake medium gable roof with major off-set gable on south (main) facade, coursed rubble faced foundation all aspects. Large coursed rubble stone exterior chimney, east elevation. Horizontal clapboard exterior, vertical board and batten all gable ends. Six-over-six double-hung sash windows singly or in combinations with mullions. Porch above main entrance formed by offset gable roof, supported by squaredtimber posts with slender, curving brackets, affixed. Small, open platform raised, of coursed rubble, flagged surface, five plain, straight side steps, stone. No decoration. No apparent exterior alterations.

Residence \#1053: 1933-37; Rectangular,

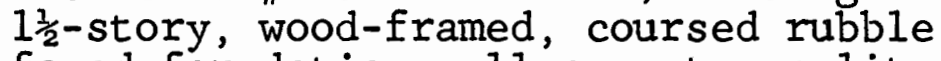
faced foundation, all aspects, splitshake medium gabie roof, with off-set projecting gables on south (main) and north (rear) facades, south off-set gable 
Tieton Ranger District

R6-17-09-DE5

roof, wood-shingled. Large coursed rubble exterior chimney, east elevation, coursed rubble interior chimney, off-set, north slope. Horizontal clapboard exterior, vertical board and batten on all gable ends. Eight-light vertical sashes in combinations of two and three with mullions; six-over-one double-hung sashes. No decoration. Apparent enclosed addition extends across north elevation to the formerly projecting off-set gable, now incorporated shed-roof covered with corrugated material.

R6-17-09-DE6

Barn \#2450: 1933-37; Large, rectangular, wood-framed, split-shake medium gable roof with five triangular dormers set equidistant immediately above the eave line on both north and south elevations. Each dormer encloses a nine-light sash window. Horizontal clapboard exterior, vertical board and batten on gable ends and dormer pediments. Two large vertical-board slide-opening doors on west gable end, one similar door centered on west gable end. Hay doors on each gable end. No decoration. No apparent exterior alteration. Unusual design. 
Lowel1 Ranger District

R6-18-06-DE-RI Do11y Varden Campground: 1933; 2 acres; Separate spacious and semi-secluded campsites, now used as picnic sites for day use only. No original campground furnishings visible; entry road graveled; parking areas marked with large rocks, landscape development intact.

$\mathrm{R} 6-18-06-\mathrm{DE}-\mathrm{R} 2$

Winberry Campground: 1936-37; 5 acres; Spacious campsites, semi-secluded. Buried oil-barrel-type fireplace with iron-bar grate. No original campground furniture visible. Recently constructed A-frame shelter, split-shake exterior with corrugated sheet metal over length of ridge, poured concrete foundation and platform. Gibbet-type entry sign post may derive from CCC construction.

$R 6-18-06-D E-R 3$

Big Pool Campground: $1933-34$; 1 acre; Separate, spacious and semi-secluded campsites, parking spaces marked with large rocks. Two cement water hydrants remain, no other original campground furnishings visible.

R6-18-06-DE-R4 Clark Creek Organization Camp, Community Building: 1936-37; Rectangular, log construction, flagstone floor, medium gable roof, stepped, split-shakes with comb ridge treatment, coursed squaredrubble masonry fireplace and interior chimney, off-set. Structure is open on north, south and west elevations enclosed on the east end; massive logs with straight, round support the roof, with large diameter ridge pole and lintels, pole purlins; east end is enclosed by tightly fitted vertical logs of medium diameter to eaveline, gable end is enclosed by similarly spaced vertical poles. The enclosed area is lighted by three six-light sash windows. The west gable end is enclosed by a truss of three members. The structure is furnished with log tables and benches. The enclosed east end houses a wet sink and food-preparation area. The roof was 
R6-18-06-DE-R4 re-shaked, in like kind in 1959-60; the flagstone floor has been re-worked; the fireplace mantel has been replaced as have the $\log$ tables and benches, apparently in like kind also. The table design is interesting: six large logs, upright form the base on which two poles are fixed lengthwise; the table surface is formed by small-diameter half-logs placed cross-wise. Fiberglass skylights have been implaced in the roof above the kitchen area.

R6-18-06-DE-R5 Shady Del1 Campground: 1933-36; 4 acres; Separate, spacious, and semi-secluded campsites, well-screened. Original furnishings now absent, except for a random-rubble masonry water hyrant.

R6-18-06-DE-R-RE1 Puma Creek Campground: 1933-34; 6 acres; Original campsites are well-separated, spacious and secluded. No original campground furniture visible. Concrete foundations of community kitchen/shelter remain, in outline. 
COLVILLE NATIONAL FOREST

Kettle Falls Ranger District

Growden CCC Campsite

R6-21-02-DE-CCC-I "Bathhouse": Rectangular, unpeeled log construction on concrete platform; wood shake medium gable roof; log and wall shake exterior; log-framed door and window openings--no doors/casements; sound structurally/materially; no visible alteration. Structure exhibits highly-skilled log-construction techniques: corner logs have battered ends--ends extend and taper as in buttress at each corner; door and window frames cut and fitted with precision; oakum chinking; unaltered; not in current use.

R6-21-02-DE-CCC-2 Powderhouse: Smal1, rectangular, corrugated metal and concrete; shed roof; single heavy door. Unaltered; not in current use.

R6-21-02-DE-CCC-3 Fountain: Octagonal concrete, reflecting pool; exterior rock-faced; fountain-tapering, random-stacked, angular-plates, nortared; circular metal catch-basin with single round pipe protruding. In very good condition--unaltered; not in current use.

R6-21-02-DE-CCC-4 Dam and Reservoir: Earth-fill dam; concrete gates; reinforced concrete pier; wood control house with wood-shake gable roof. Reservoir silted in. 
Newport Ranger District

$\mathrm{R} 6-21-03-\mathrm{DE} 1$

R6-21-03-DE2

R6-21-03-DE3

R6-21-03-DE4

R6-21-03-DE5
Newport Ranger Station Office 非2010: 1940; Rectangular, 1-story, wood-frame, concrete foundation, low gable roof; horizontal clapboards to window-level, vertical board and batten above, wood corner trim; off-center gabled porch; wood casement and sash windows. 1720 sq. ft. No decoration. Textured metal roof material. Well-maintained.

Newport Ranger Station - Silviculture Office 非312: 1940; Rectangular, 1-story, wood-frame, basement-poured concrete, low gable roof; horizontal clapboards to window-level, vertical board and batten above, wood corner trim; center gable hood; wood casement and sash windows. $1500 \mathrm{sq}$. ft. No decoration. Textured metal roof material, metal stairs with railings. Well-maintained.

Newport Ranger Station - Vehicle Storage 非318，非320：1940； T-shaped, 1-story wood-frame, concrete foundation, low gable roof with cross-gable on north; horizontal clapboards to window-level, vertical board and batten above, wood corner trim; five bays-vehicle storage, sliding paneled doors. $2200 \mathrm{sq}$. ft. No decoration. Textured metal roof material. Well-maintained.

Usk Guard Station Garage: ca 1940; Rectangular, wood-frame, low gable roof, wood shakes; horizontal shiplap, wood corner trim. Two-leaf, hinged, reinforced doors on south gable end. Singlevehicle capacity. Windows covered.

Usk Gard Station Warehouse: 1940; Lshaped, wood-frame, medium gable roof with off-set gable, north, horizontal shiplap, wood corner trim. Uncovered entrances, wood platforms, side-steps and railings. Corrugated metal roof, windows covered. 
Newport Ranger District

R6-21-03-DE-R1 Browns Lake Cabin: 1940; Rectangular, wood-frame, $12^{\prime} \times 20^{\prime}$; medium gable roof, wood shakes; horizontal clapboards, vertical board and batten-gable ends. Fenestration regular-windows covered. Center gable hood. No decoration.

Good condition. No apparent exterior alteration.

R6-21-03-DE-R2 Browns Lake Campground: ca 1940;

Developed public occupancy site, level 2. No original campground furniture remains. Dry-masonry stone walls along lake access path. 
COLVILIE NATIONAL FOREST

Republic Ranger District

R6-21-04-DE-R1 Swan Lake Community Kitchen: 25'x32'; Rectangular, peeled $\mathrm{log}$ and pole construction, concrete platform, splitshake medium gable roof, pole ridge treatment. Nine uniform medium diameter peeled log posts, each with two round brackets, gable ends open, structure semi-enclosed railing on east, west and south elevations, three uniform medium diameter peeled logs stacked, saddle notched corners, buttressed ends, north elevation enclosed to height of log railing by coursed, rubble wall. Large coursed rubble chimney centered on north elevation. Two side stoves having cast iron doors exhibiting U. S. Forest Service shield. Entrance, center south facade, approached by three peeled log steps running the length of the structure. In good condition. Some shakes missing from north east corner of roof.

R6-21-04-DE1

Republic Ranger Station Compound, "Yellow

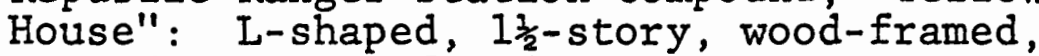
poured concrete foundation, compositionshingle hipped gable roof, intersecting hipped gable off-set on south facade. Enclosed hipped gable porch on west elevation, shed porch roof extends from main slope on south to cover poured concrete platform and entry, supported by a single wall-shaked post, bellcast shed roof on intersecting gable forms bay. Stretcher bond brick exterior chimney, east elevation. Interior brick chimney, off-set on south slope main gable. Wall-shake exterior. Six-overone double-hung sash windows. No decoration. Three large windows on south (main) facade replaced with plate glass. 
Republic Ranger District

R6-21-04-DE2

R6-2I-04-DE3

$R 6-21-04-D E 4$
Republic Ranger Station Compound, "Pink House": Cruciform, 1-story, wood-frame, poured concrete foundation, composition shingled hipped-gable roof with center cross gable. Wall-shake exterior. Threeover-one double-hung sash windows, six vertical light sashes on center cross gables, flanked by chamfered pillasters with Roman-Doric capitals. No decoration. No obvious structural alteration to exterior.

Republic Ranger Station Compound, "Green

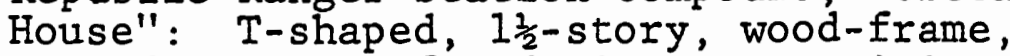
poured concrete foundation, composition shingled hipped gable roof, bellcast eaves, off-set gable on south facade, off-set bag, 1-story, north facade, enclosed gable-roofed porch on west elevation, stretcher-bond brick exterior chimney, west elevation, incorporating contrasting, double-ended key design, upper center, stretcher-bond brick interior chimney, north roof slope. Wall-shake exterior. Eight-vertical-light single sashes, twelve-light single sashes, singly and in combinations with mullions. No decoration. Replacement of multi-light sash windows with single-pane plate glass; corrugated fabric covers bellcast eaves.

Republic Ranger Station Compound, Stockade: Rectangular, wood-frame, wood-shingled medium gable roof. Horizontal clapboard, exterior, vertical boards, triangular corner cuts on gable ends. Five bays in length, two bays in depth; large, slide opening doors with two eight vertical light windows surmounted by two four-light wood windows on north elevation doors removed on south elevation. On each gable end, two large mullion windows of three twentylight sashes surmounted by three twelvelight sashes. Centered on each gable end, a linear design of three pine tree cut outs, a distinctive three-unit center tree flanked by two smaller trees of slender proportions. Each tree is cut from center of a single board. 
Sullivan Lake Ranger District

R6-21-05-DEI

R6-2I-05-DE2

R6-21-05-DE3

R6-21-05-DE4
Sullivan Lake Ranger Station Office 非2006:

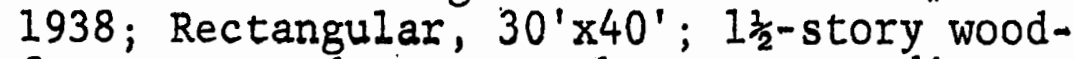
frame, poured-concrete basement, medium wood shingle gable roof with large gableroofed center dormer on north slope; wood shingle exterior; regular fenestration of horizontal and vertical combinations of sash windows. Main entrance, off-center on south facade, low gable porch, wood platform with railing, enclosed below entrance level with wood latice. No decoration. No apparent exterior alteration. We1l-maintained.

Sullivan Lake Ranger Station Vehicle Storage 非307: 1934; Rectangular, 24'x74'; 1-story, wood-frame, saltbox, woodshingle roof; wood-shingle exterior. Horizontal single-sash, multi-light windows. Four bays-vehicle storage four paneled doors - may be vertical lift. No decoration. No apparent exterior alteration - with possible exception of garage doors. Wellmaintained.

Sullivan Lake Ranger Station Equipment Shed 非308: 1934; Rectangular, 20'x80'; $1 \frac{1}{2}$-story, wood-frame, saltbox;

horizontal board exterior, wood corner trim; horizontal sash windows, multilight. One bay enclosed storage, three bays with sliding reinforced vertical board doors, five bays open storage. No decoration. Corrugated metal roof material. Some window lights need replacement.

Sullivan Lake Ranger Station Fire Warehouse 非401: 1934; Rectangular, 20'x42'; 1-story, wood-frame, saltbox, concrete foundation; shingle roof (? wood or composition), wood shingle exterior; horizontal 6-light, single sash windows; two reinforced diagonal-board doors. No decoration. No apparent exterior alteration. Well-maintained. 
Sullivan Lake Ranger District

R6-21-05-DE5

Sullivan Lake Ranger Station Oil House 非505, 非602: 1934; Rectangular, 14'x16'; wood-frame, poured concrete and concrete block foundation; wood-shingle medium gable roof; wood-shingle exterior. Bracket-braced gable hood, off-center above door on south gable end. No decoration. No obvious exterior alteration.

$\mathrm{R} 6-21-05-\mathrm{DE}-\mathrm{R} 1$

Sullivan Lake Campground Toilet Building 非2802: 1938; Rectangular, 12'x20'; woodframe; wood-shingle medium gable roof; wood-shake exterior, vertical board and batten on gable ends. Square post and corner-notched vertical board door screens. Green fiberglass window covers. Exterior well-maintained. No decoration.

R6-21-05-DE-R2 Sullivan Lake Campground Change House 非803: 1938; Rectangular, $16^{\top} \times 30^{\prime}$; woodframe, poured concrete foundation; woodshingle medium gable roof, lower part of west slope extends to form one-half of gable-roofed hood above doors on north and south gable ends; wood-shake exterior, vertical board and batten gable ends. Green fiberglass window covers. Exterior well-maintained. No decoration. 
APPENDIX B

Figure 3. Geographical Distribution of Depression-era Administrative Sites - Oregon.

Figure 4. Geographical Distribution of Depression-era Administrative Sites - Washington.

Figure 5. Geographical Distribution of Depression-era Recreation Sites - Oregon.

Figure 6. Geographical Distribution of Depression-era Recreation Sites - Washington.

Figure 7. Geographical Distribution of Depression-era Community Kitchens - Oregon.

Figure 8. Geographical Distribution of Depression-era Community Kitchens - Washington. 


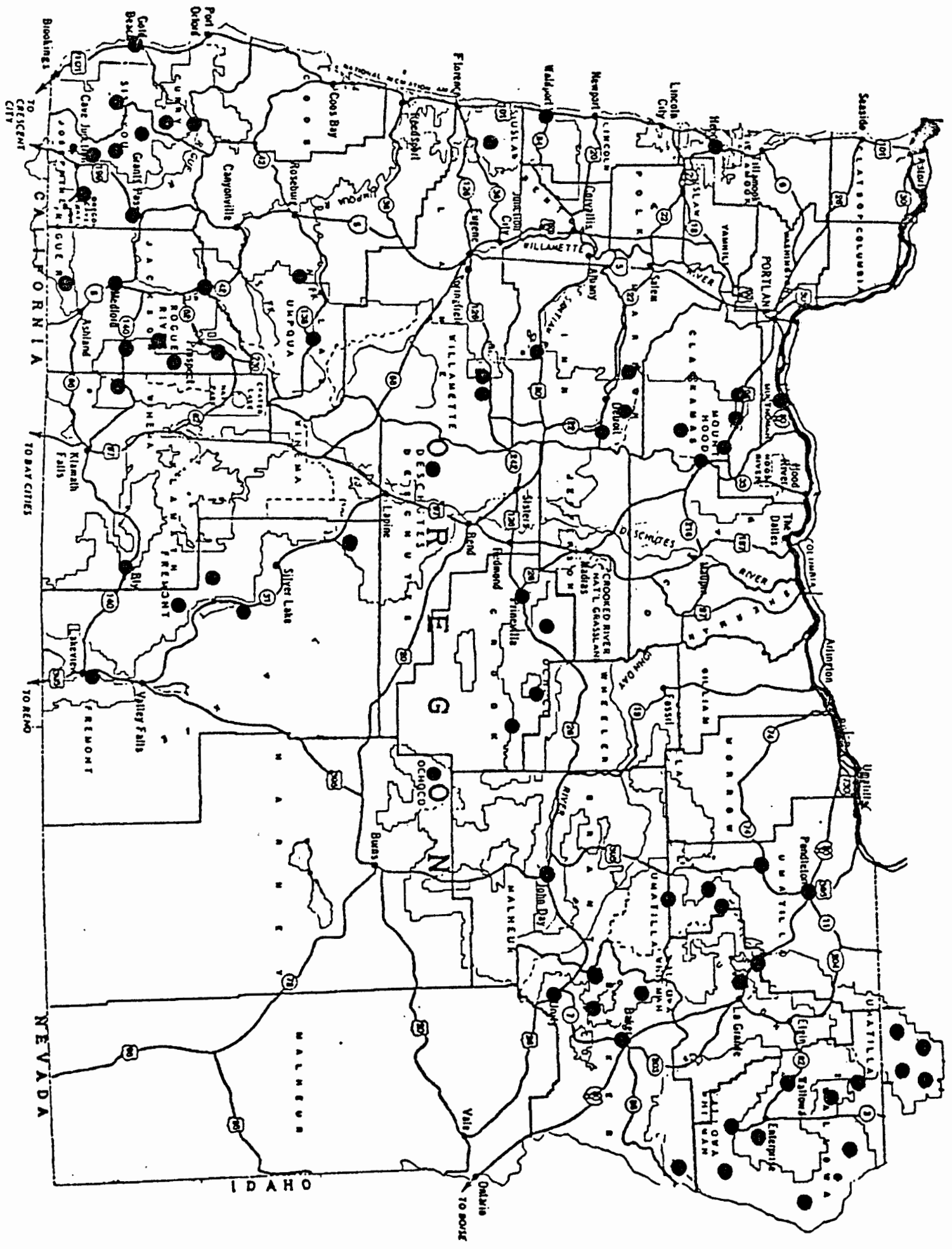

Figure 3. 


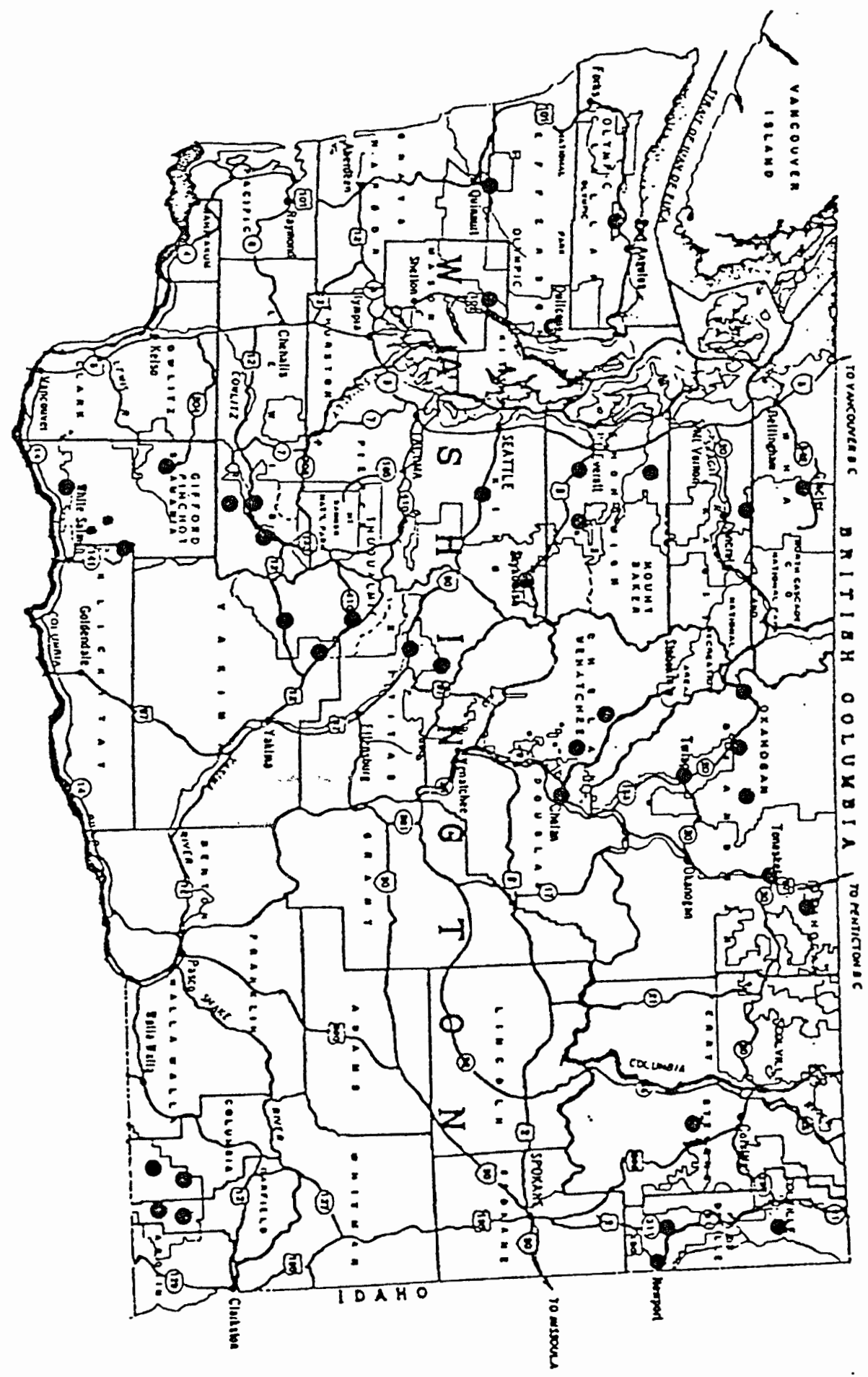

Figure 4. 


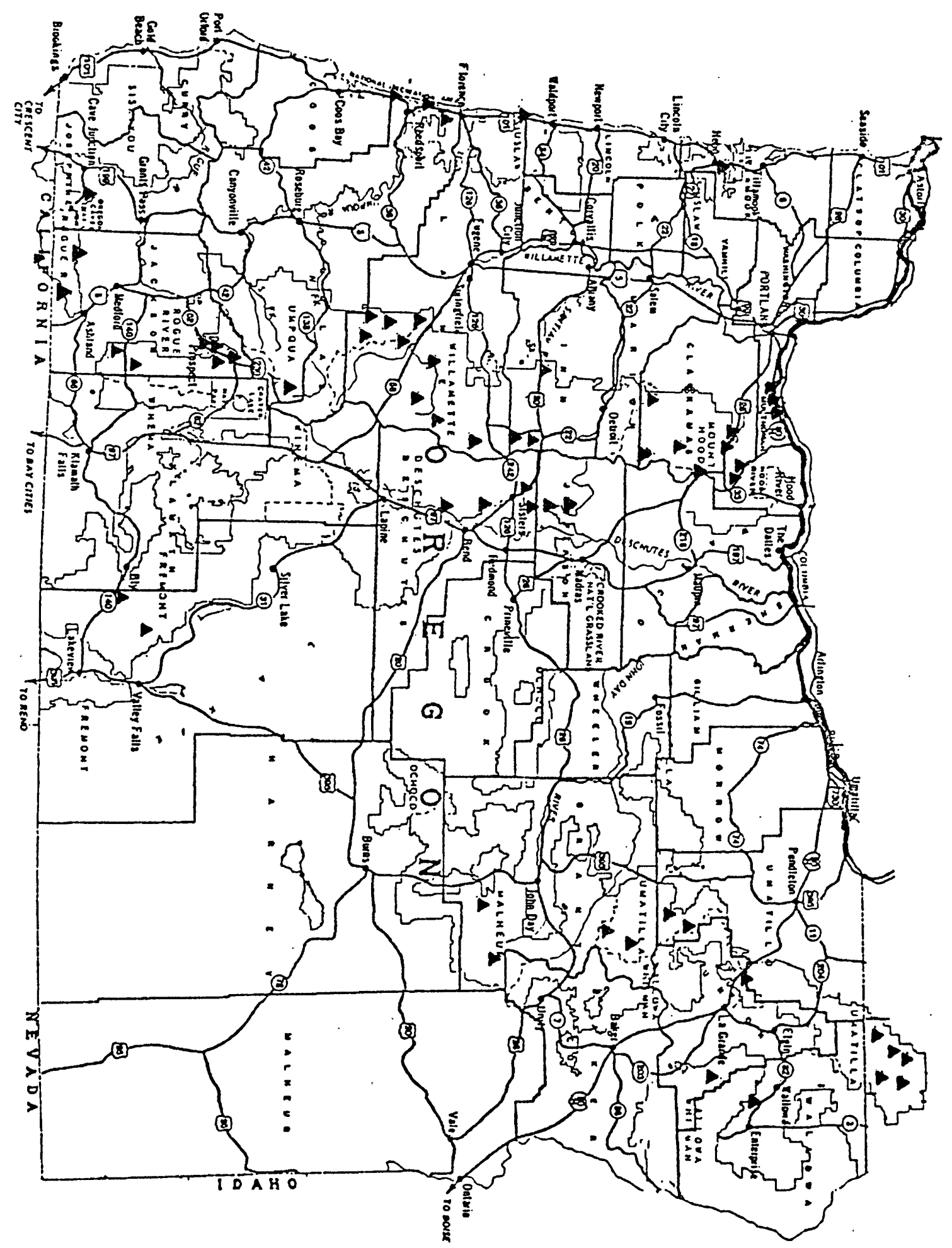

Figure 5. 


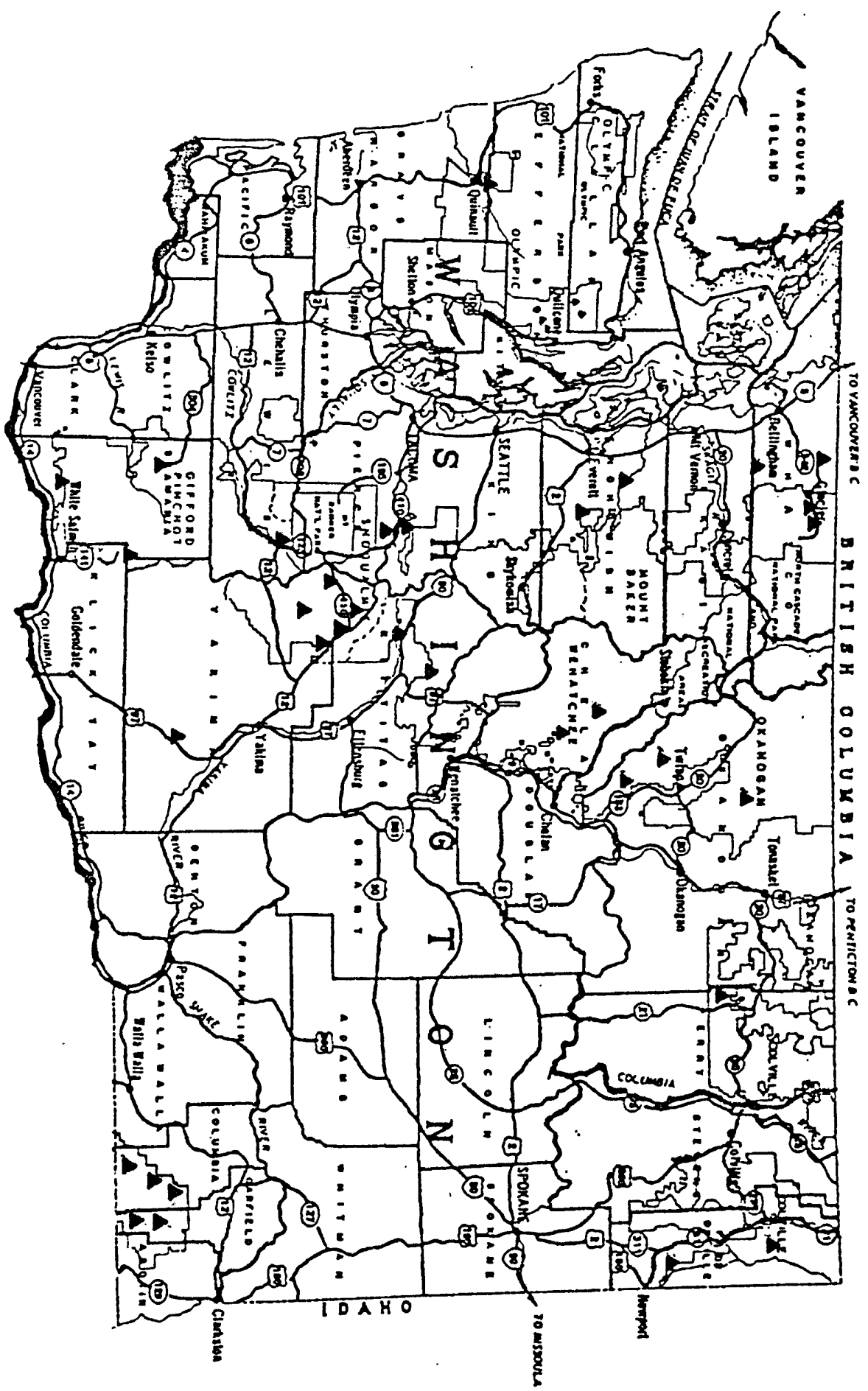

Figure 6. 


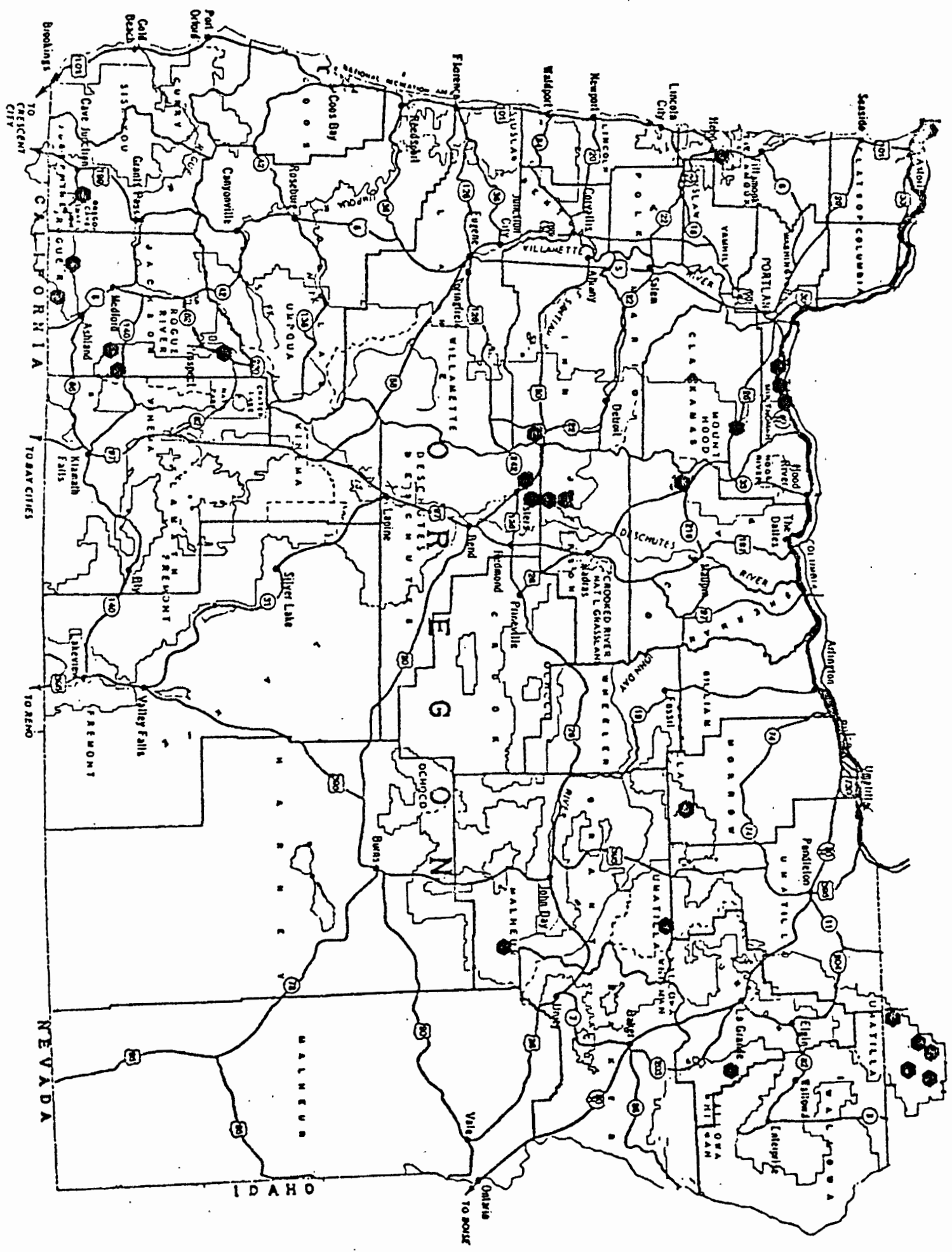

Figure 7. 


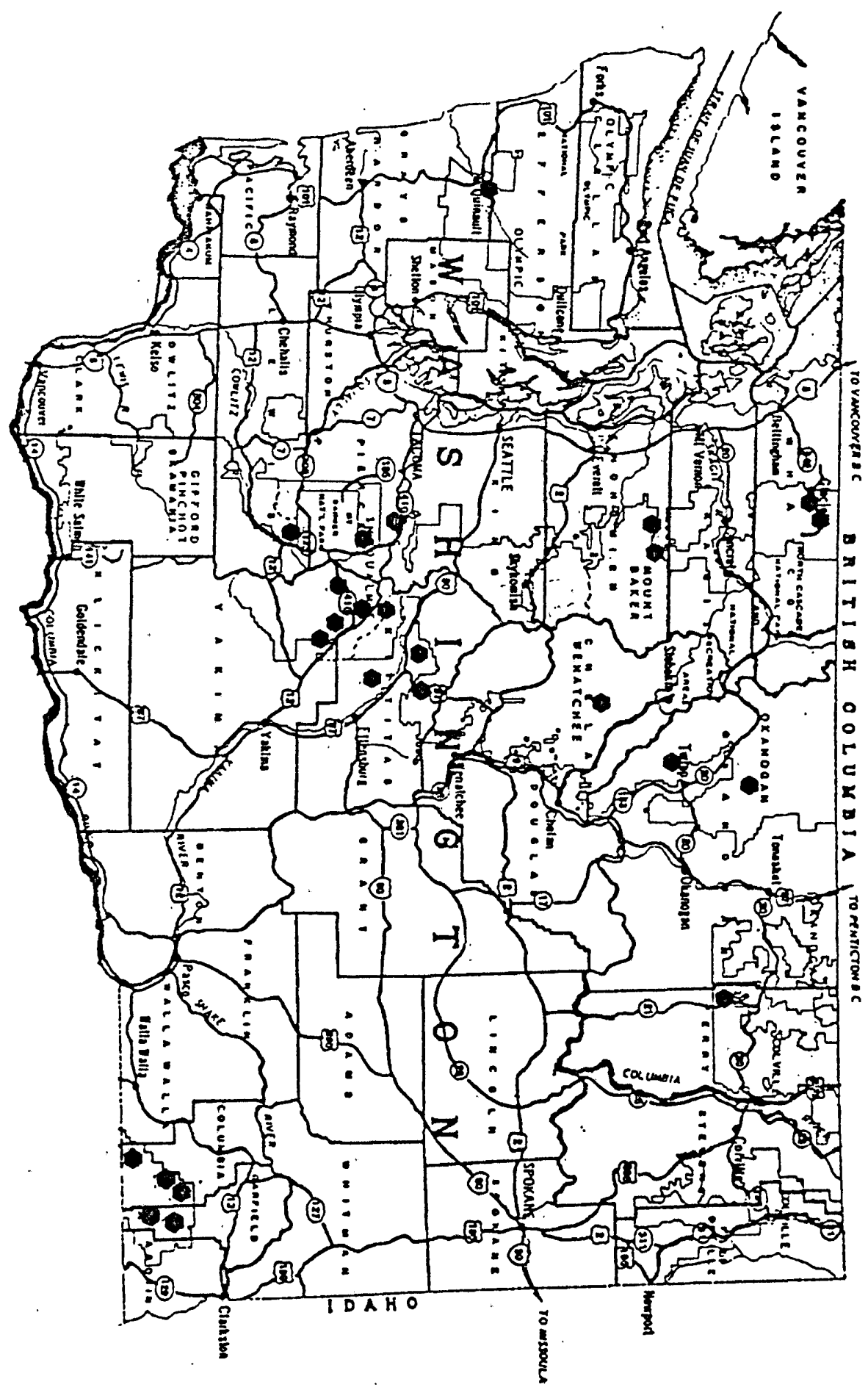

Figure 8. 


\section{APPENDIX C}

Representative illustrations from Acceptable Plans Forest Service Administrative Buildings. (Figures 9-18).

Representative illustrations from Recreation Handbook Region Six. (Figures 19-22).

Representative Elevation Plans and specifications, Gas and $0 i 1$ Storage, Rager Ranger Station, Ochoco National Forest. (Figures 23-24). 

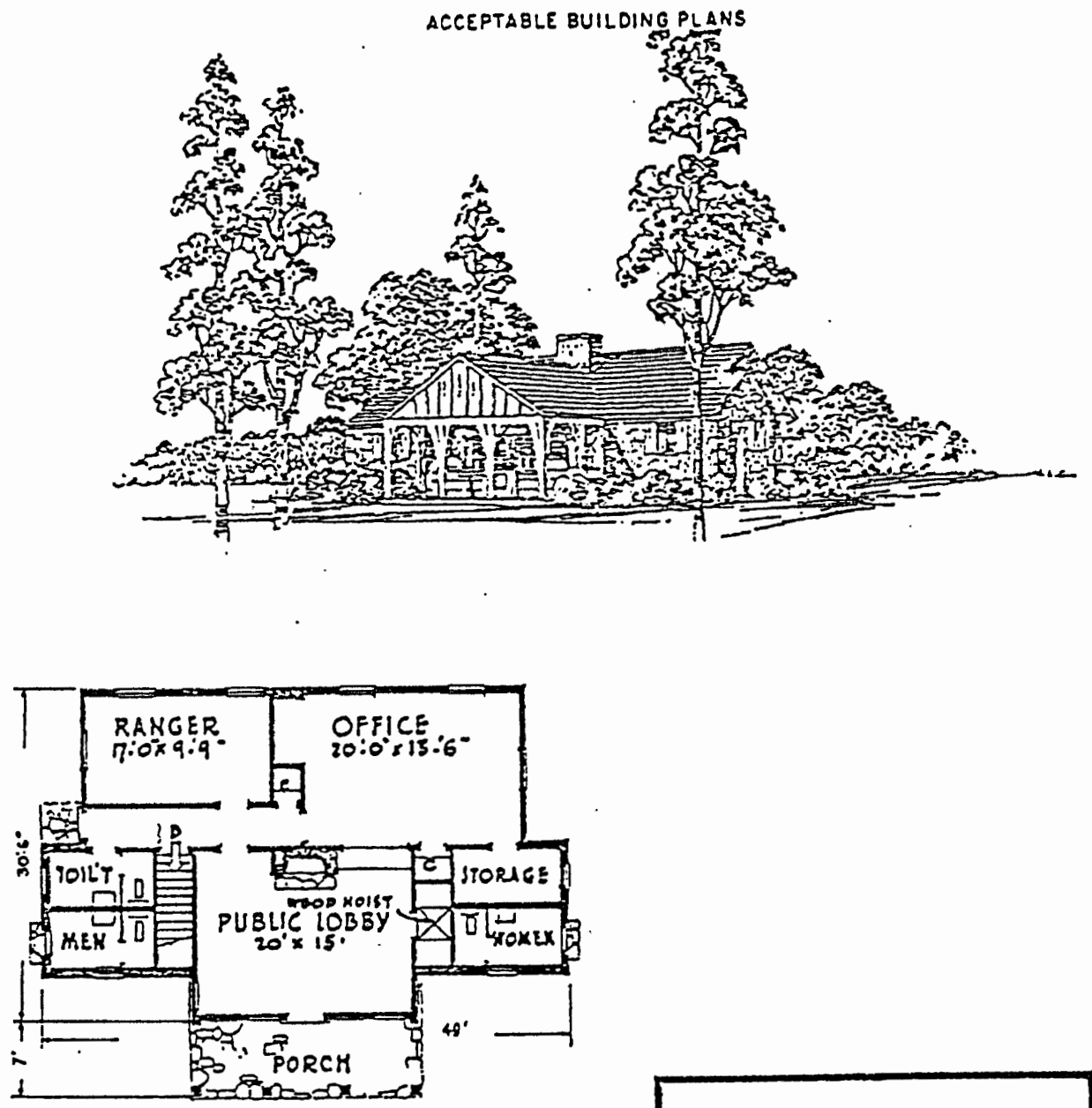

FIRST FLOOR

SCALE HO"

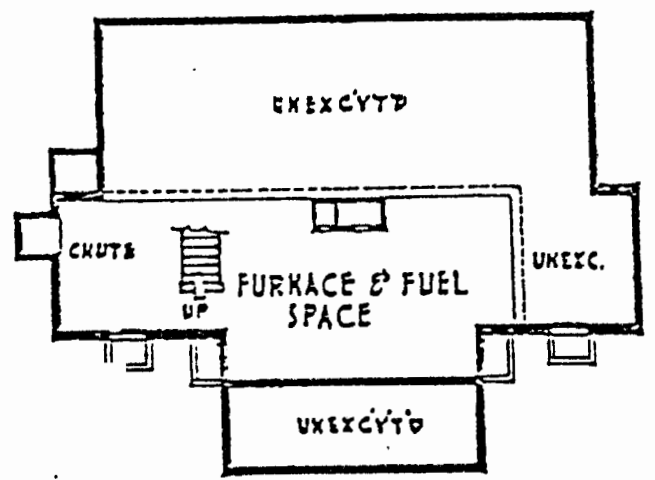

BASEMENT PLAK

THREE ROOM OFFICE \& PUBLIC TOILETS. REGION SIX.

oclimeaton

PLAN NO 116. 

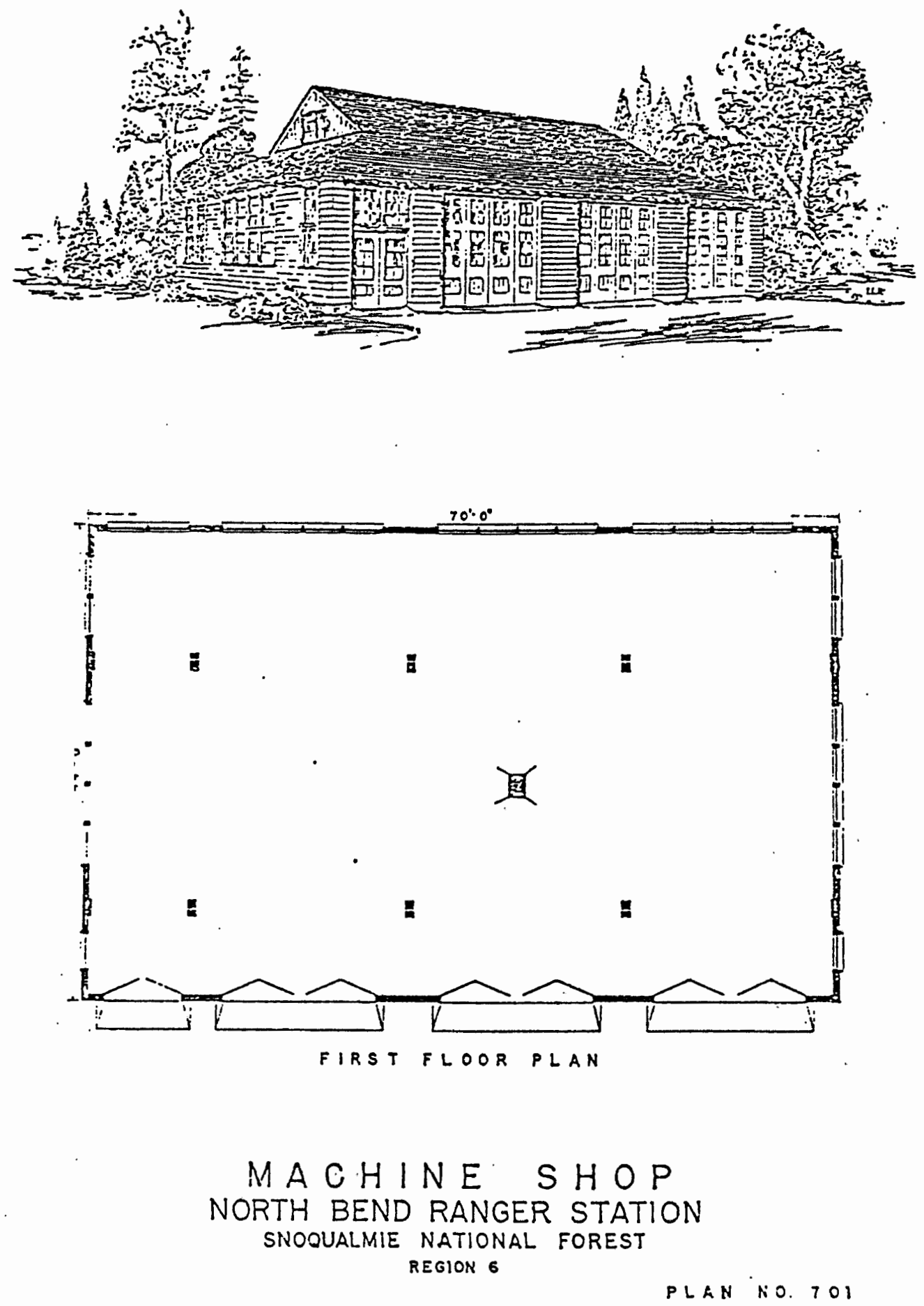

Figure 10. 

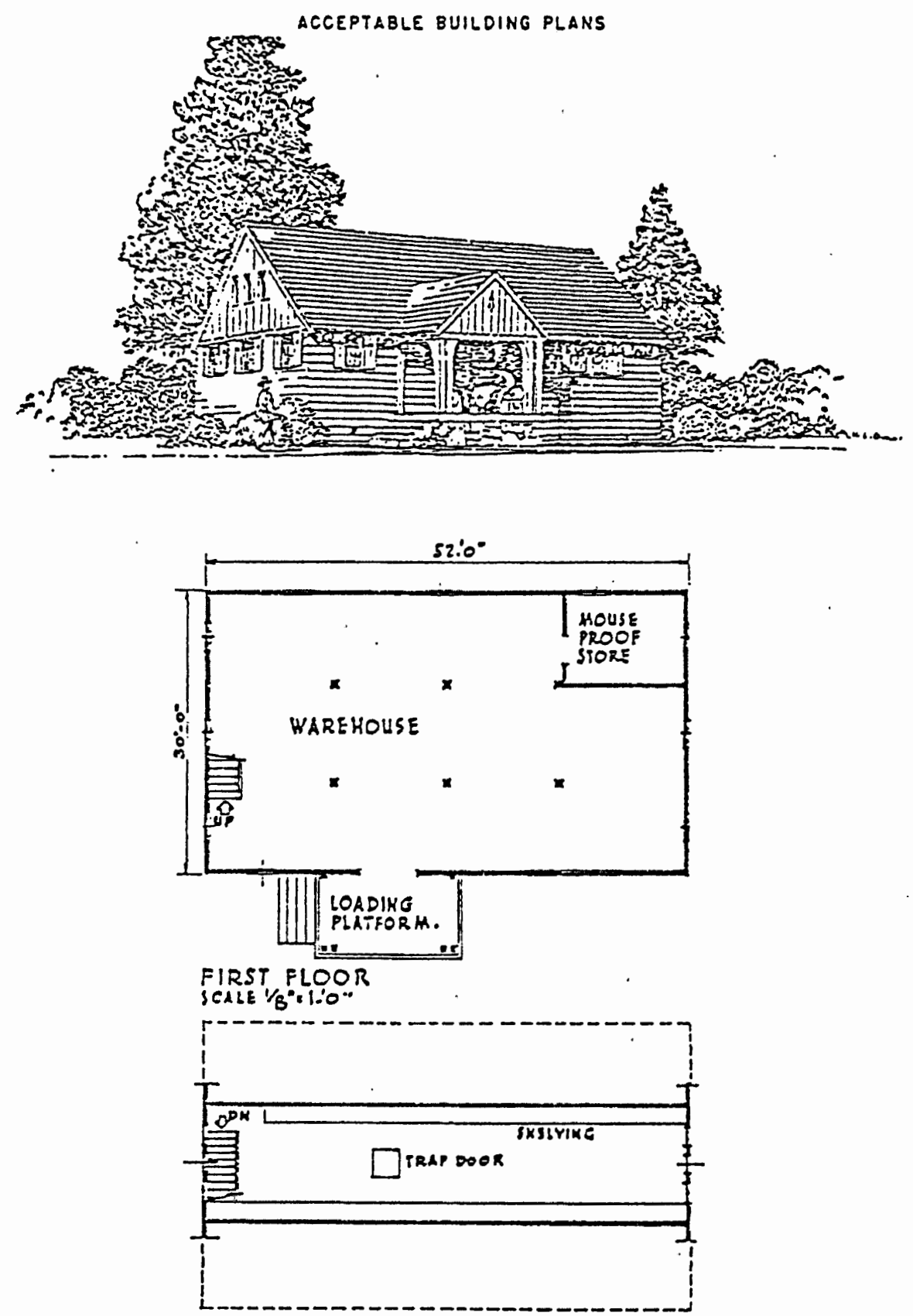

\section{SECOND FLOOR \\ FIRE EQUIPMENT WAREHOUSE REGION SIX orlineató}

PLAN NO 623.

Figure 11. 


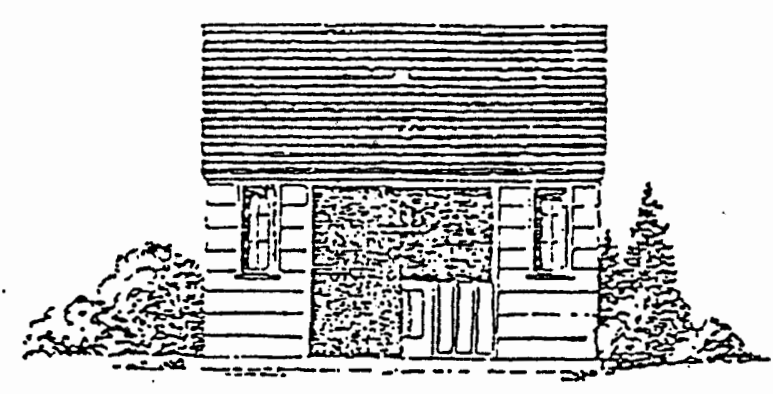

FROKT.
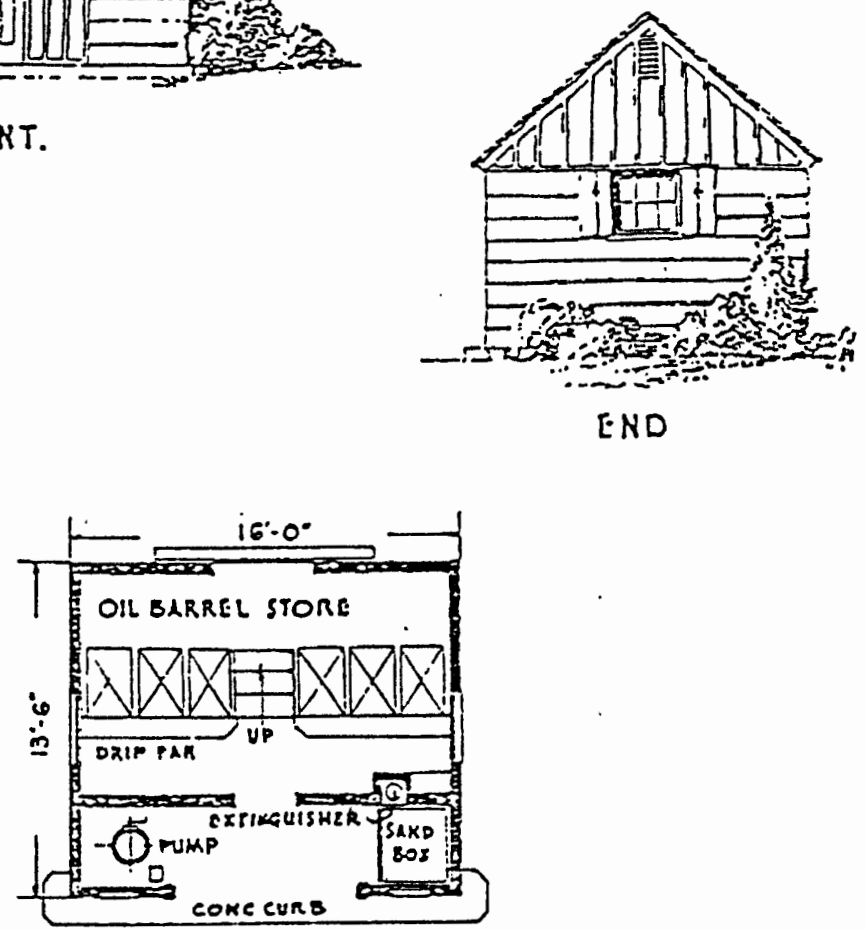

plak.

GAS \& OIL STORAGE

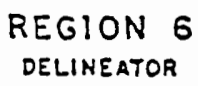

PLAN NO. 543

Figure 12. 

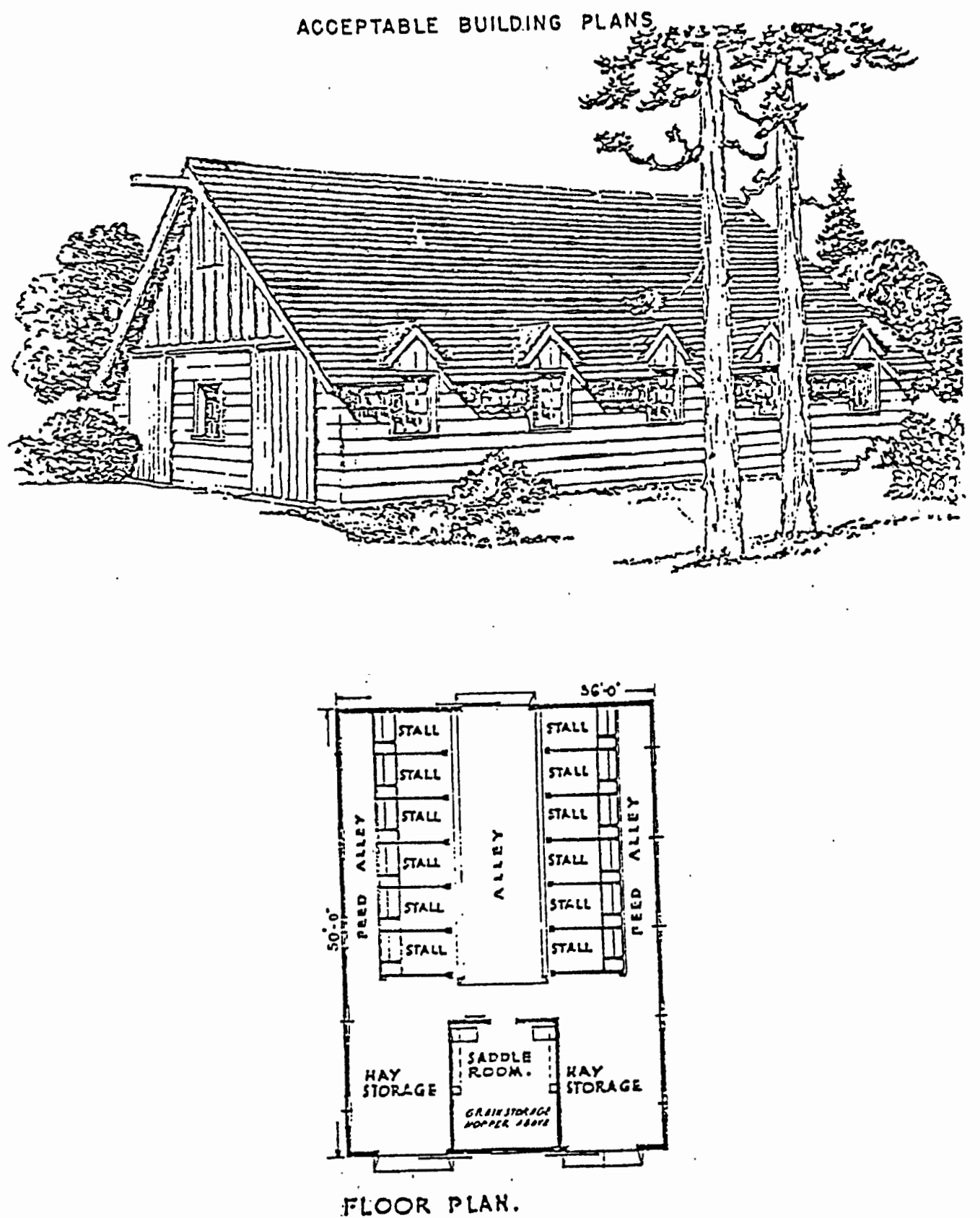

TWELVE HORSE BARN

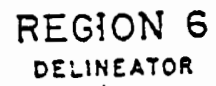

PLAN No. 804 

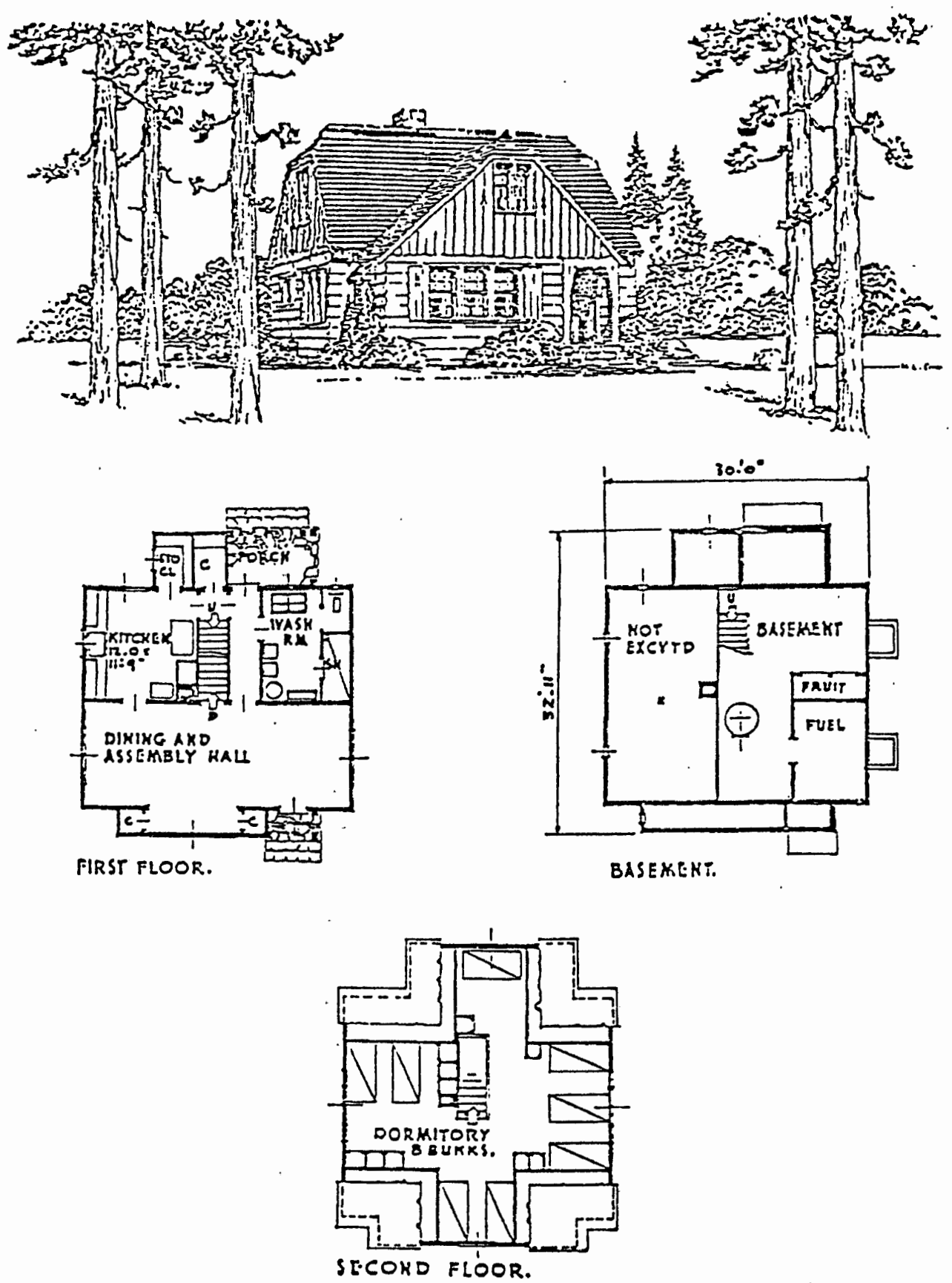

EIGHT MAN CREIV HOUSE

PLAN NO 40 !

Figure 14. 

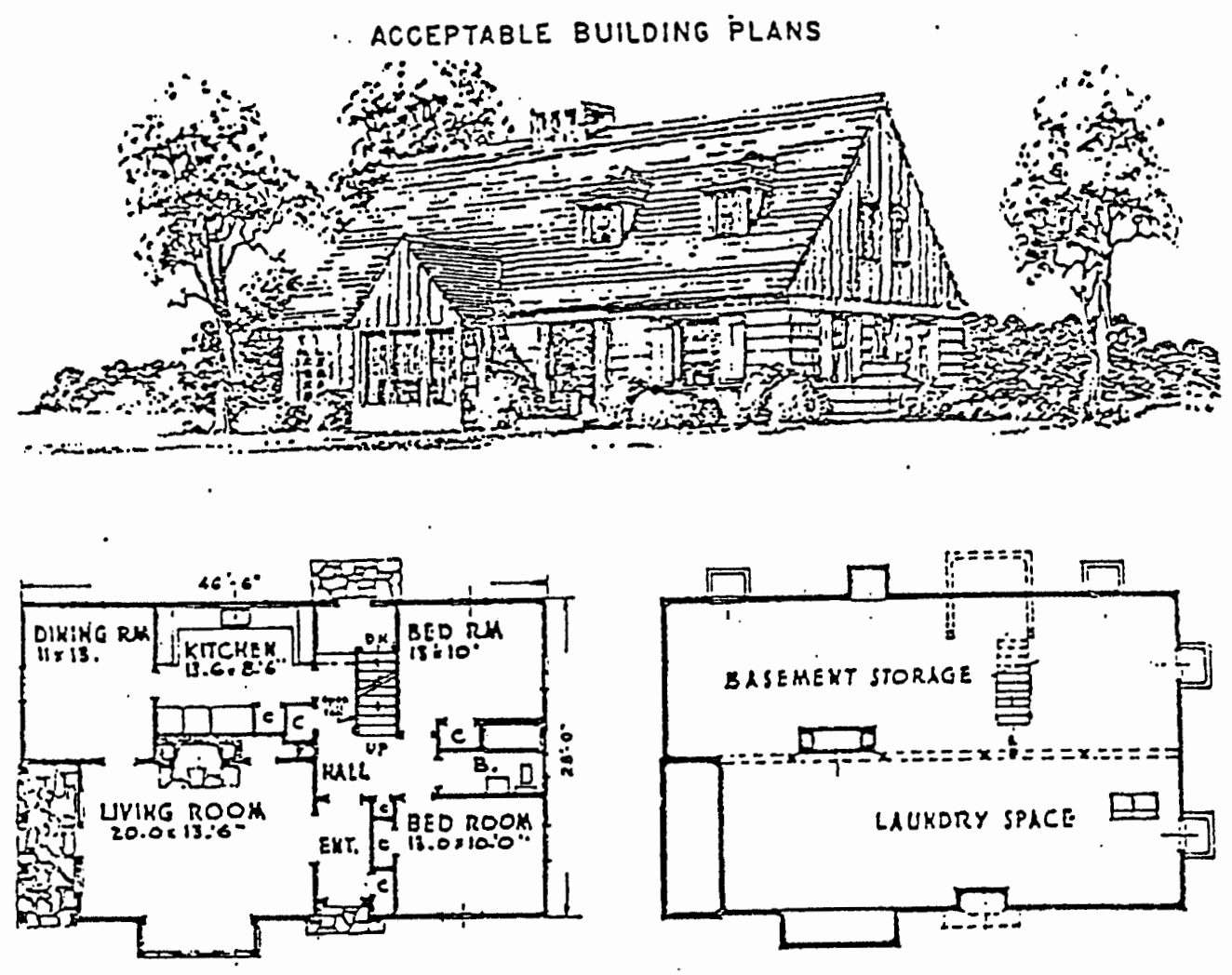

GROUND FLOOR

BASEMEKT PLAK.

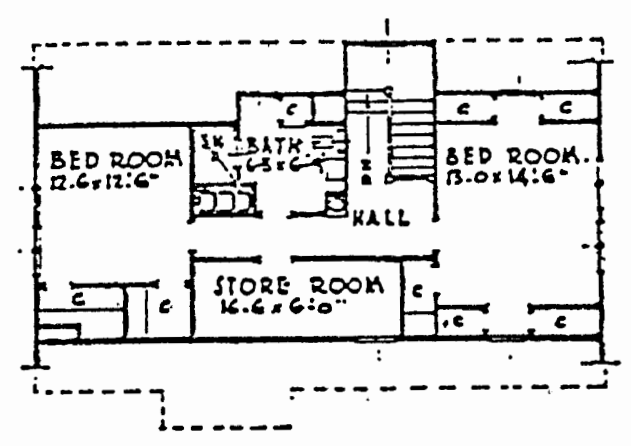

SECOND FLOOR.

SEVEN ROOM RESIDENCE

\section{REGION 6 \\ DELINEATOR}

PLAN No. 228

Figure 15. 

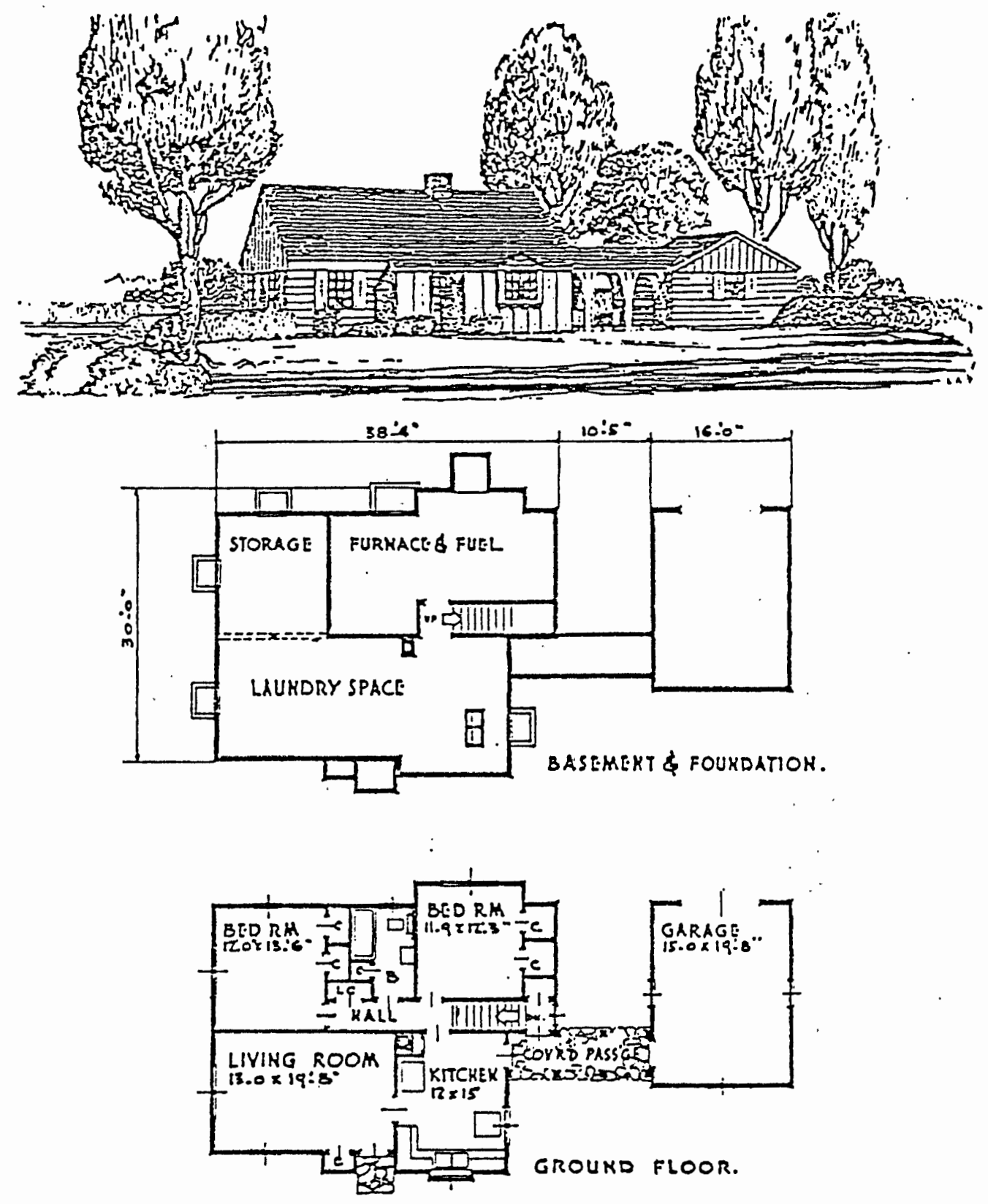

\section{FOUIR ROOM RESIDENCE RECION SIX.}

PLAN NO 328. 

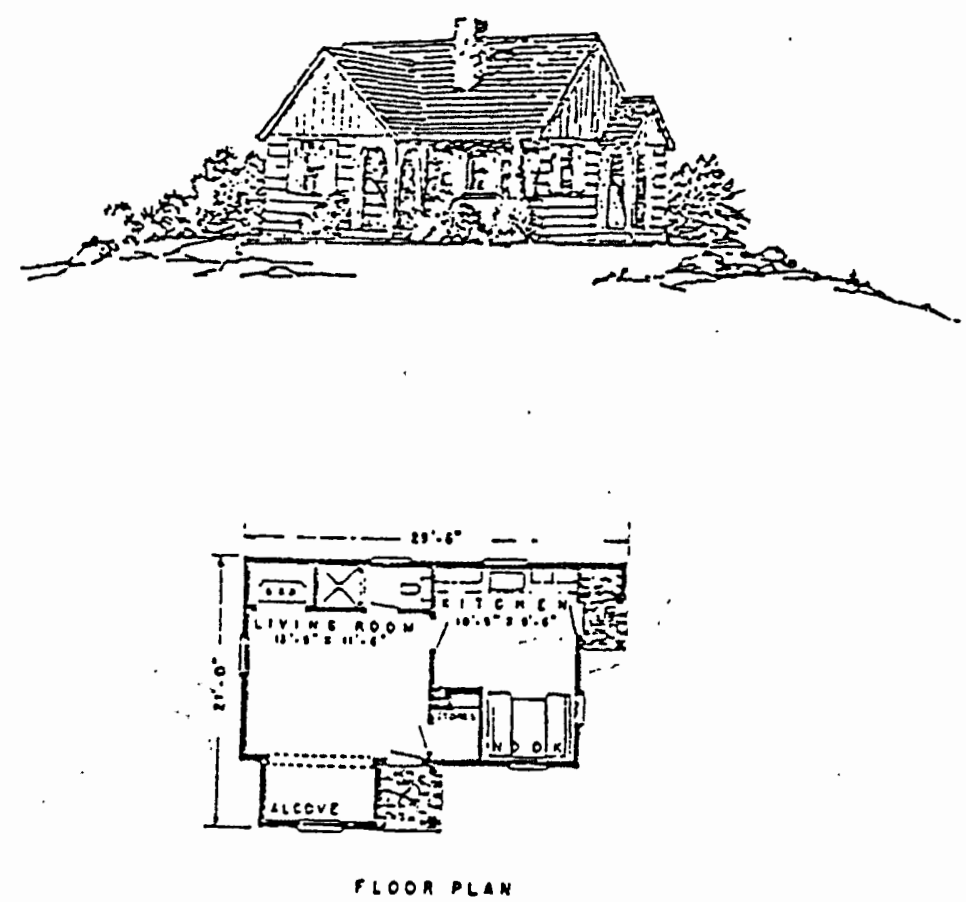

\section{TWO ROOM GUARD CABIN REGION SIX \\ delineaton}

PLAN NO $312 . A$ 

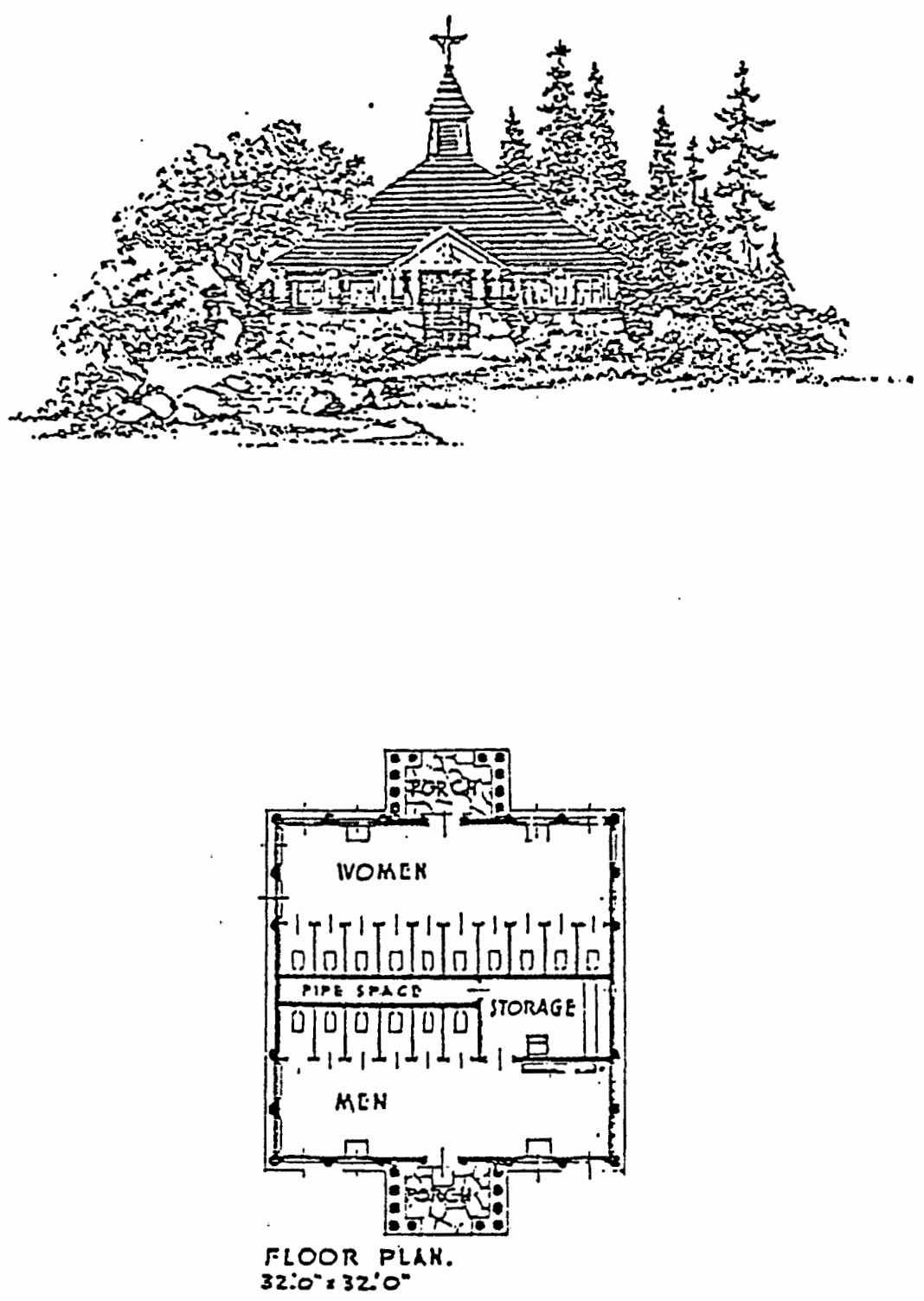

\section{PUBLIC COMFORT STATION}

PLAN KO 923. 


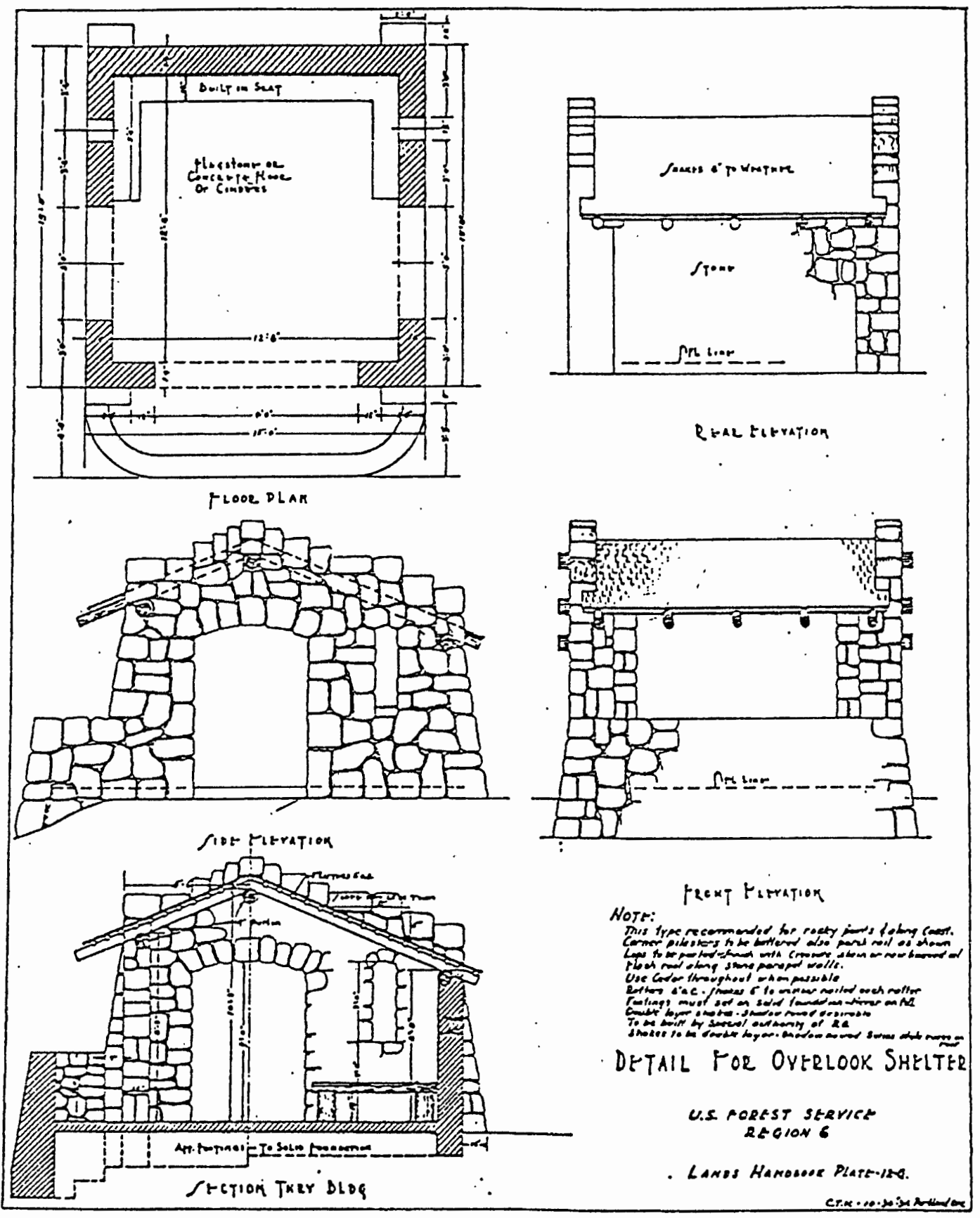




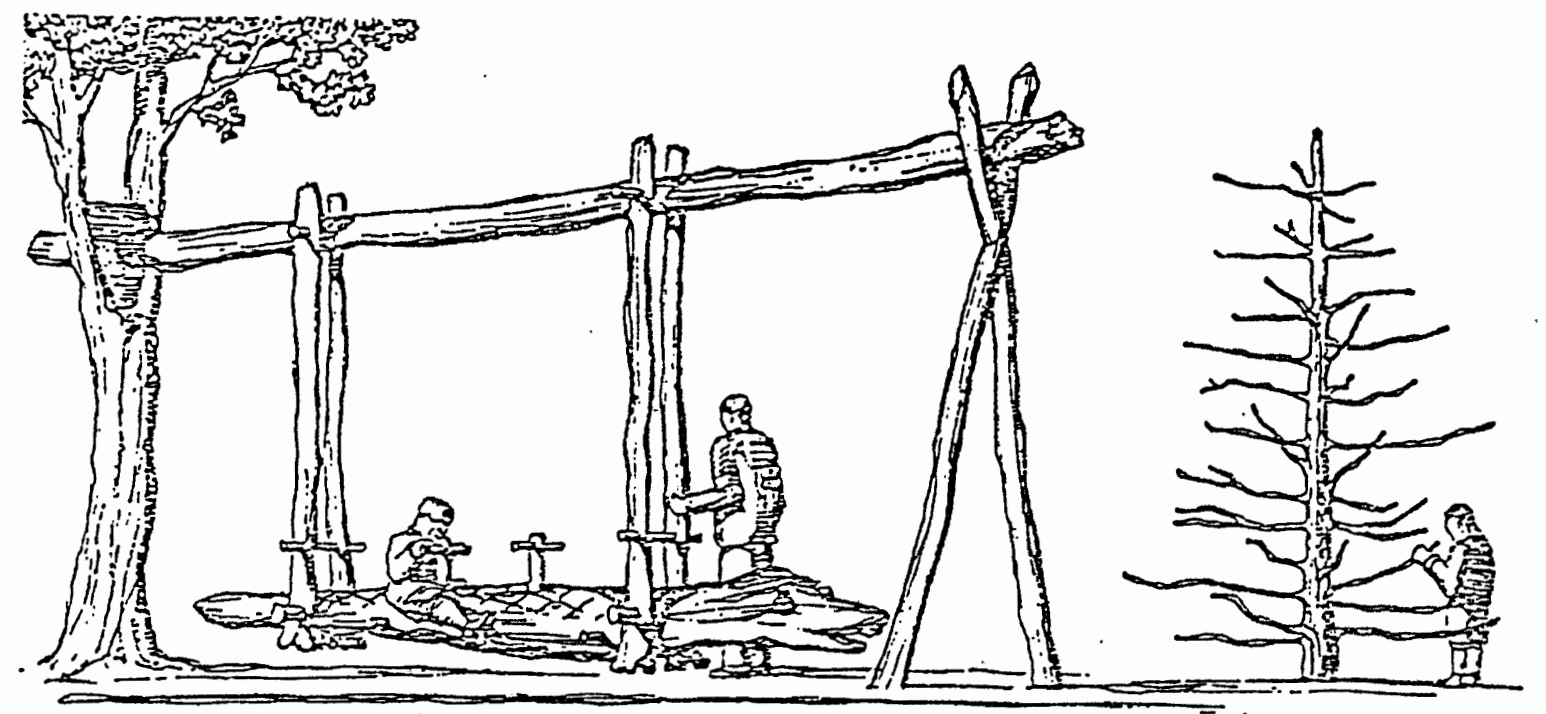

$$
\begin{aligned}
& \text { SWINC } \\
& \text { STRE. A. }
\end{aligned}
$$

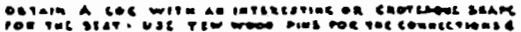

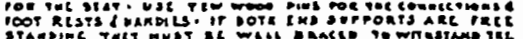
ioncitobinat omat?

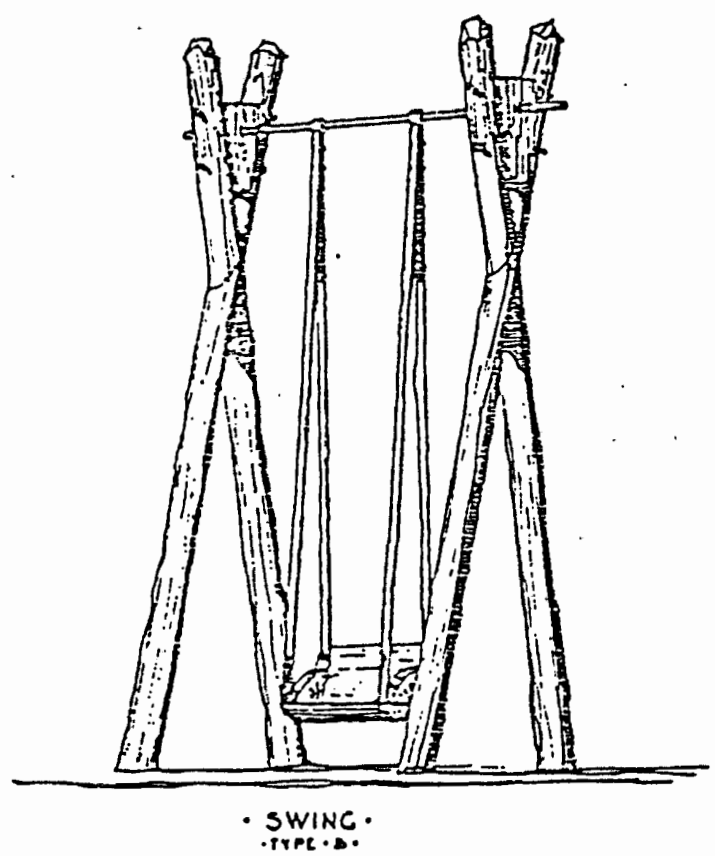

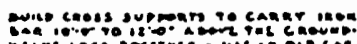

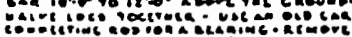

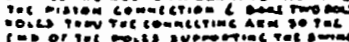
iis iaction
PLAYGROUND FACILITIES

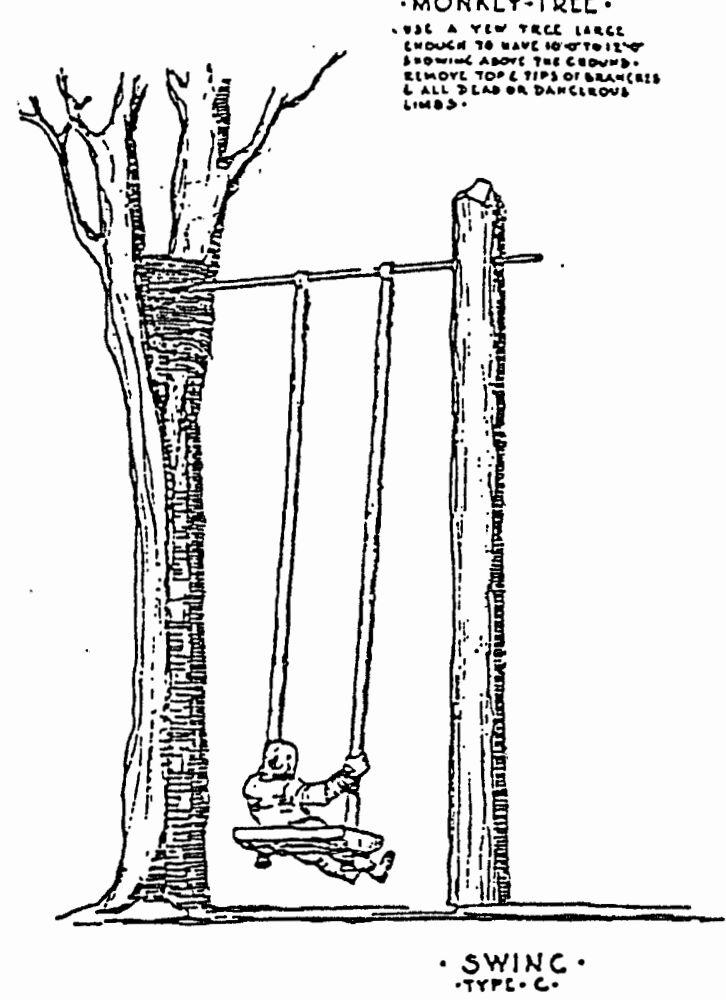

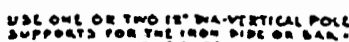

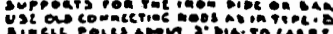

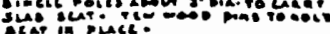

PLATE $19 H$ n...... 2 

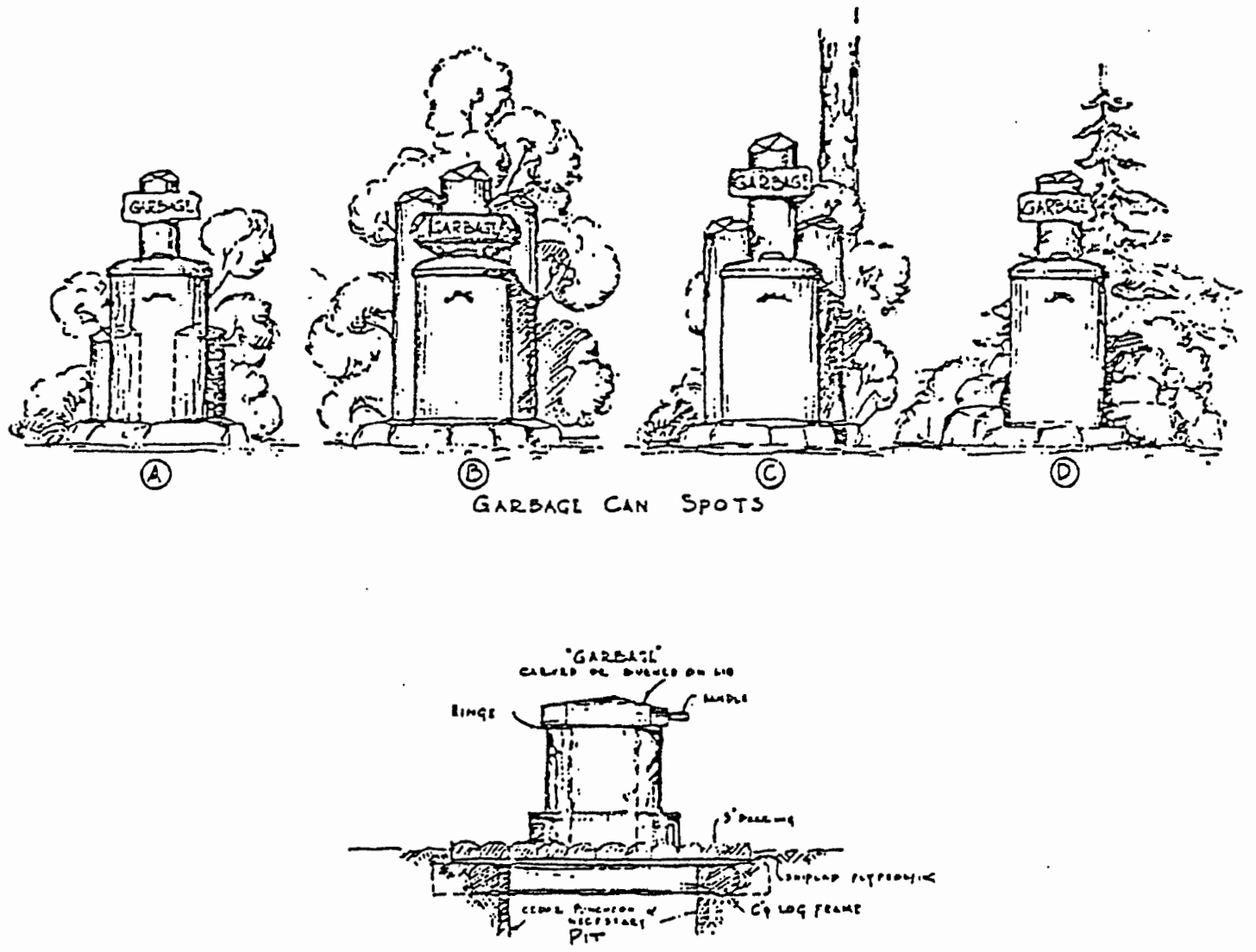

(c)

Pit Conzr frams

consterctionts.

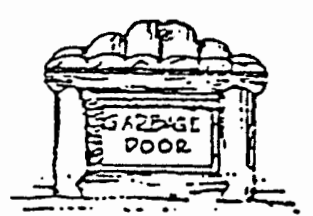

(I)

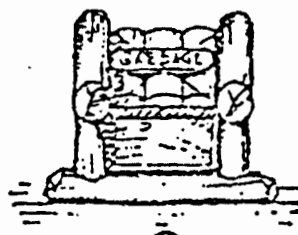

(6)

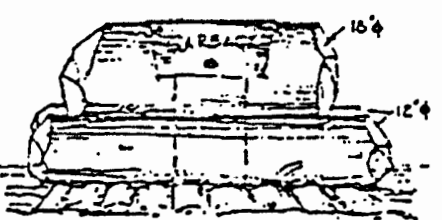

$(x$

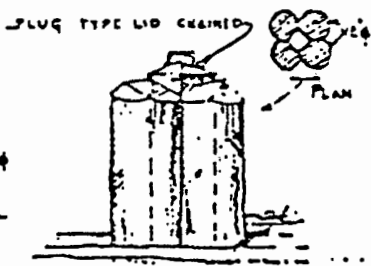

. (1)

GRRBAGE PIT TIRORTS

GARBAGE DISPOSAL

PLATE 5 

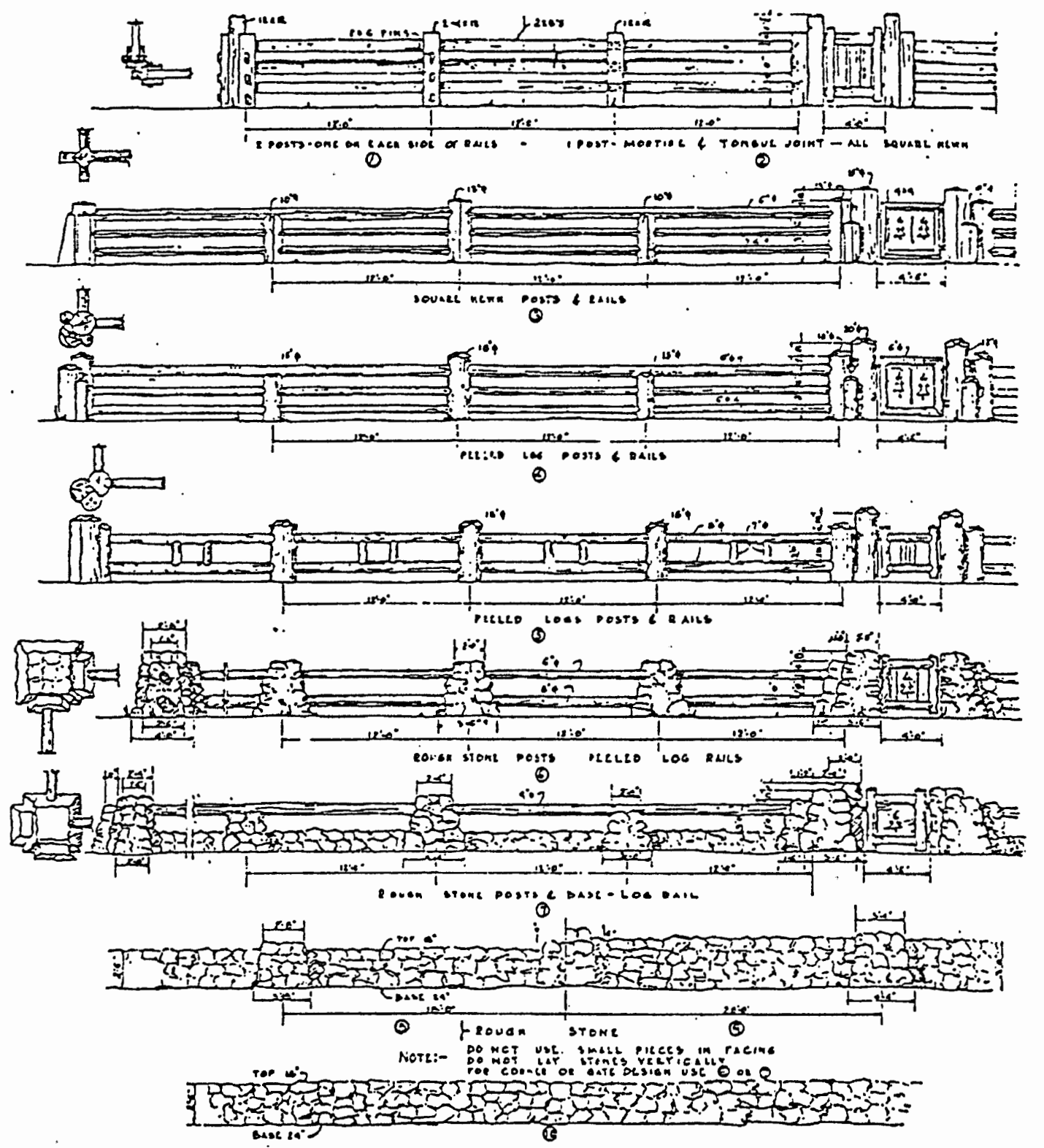

RUSTIC FENCES \& BARRICADES

PLATE IBA

. Q. . ... 


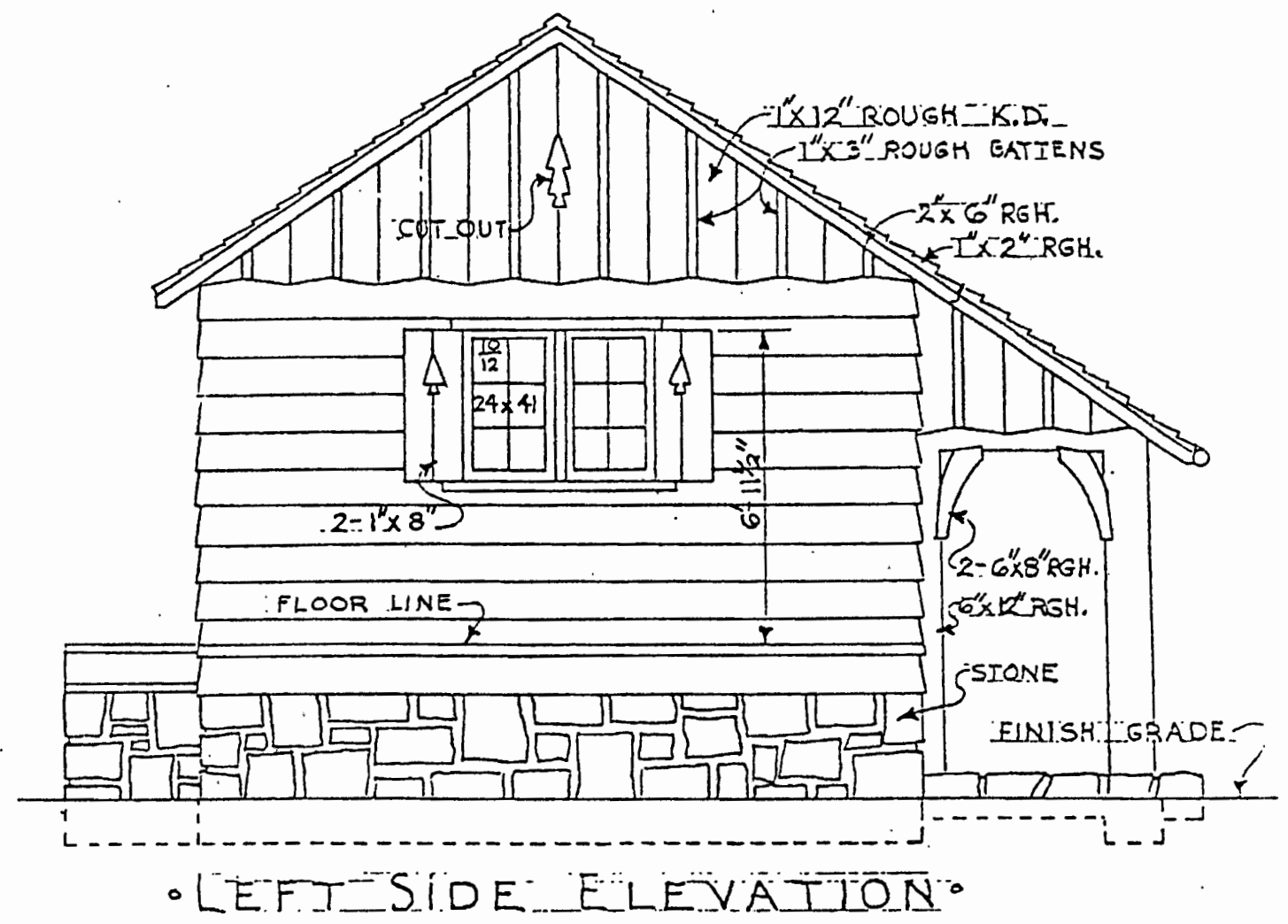

Figure 23. 


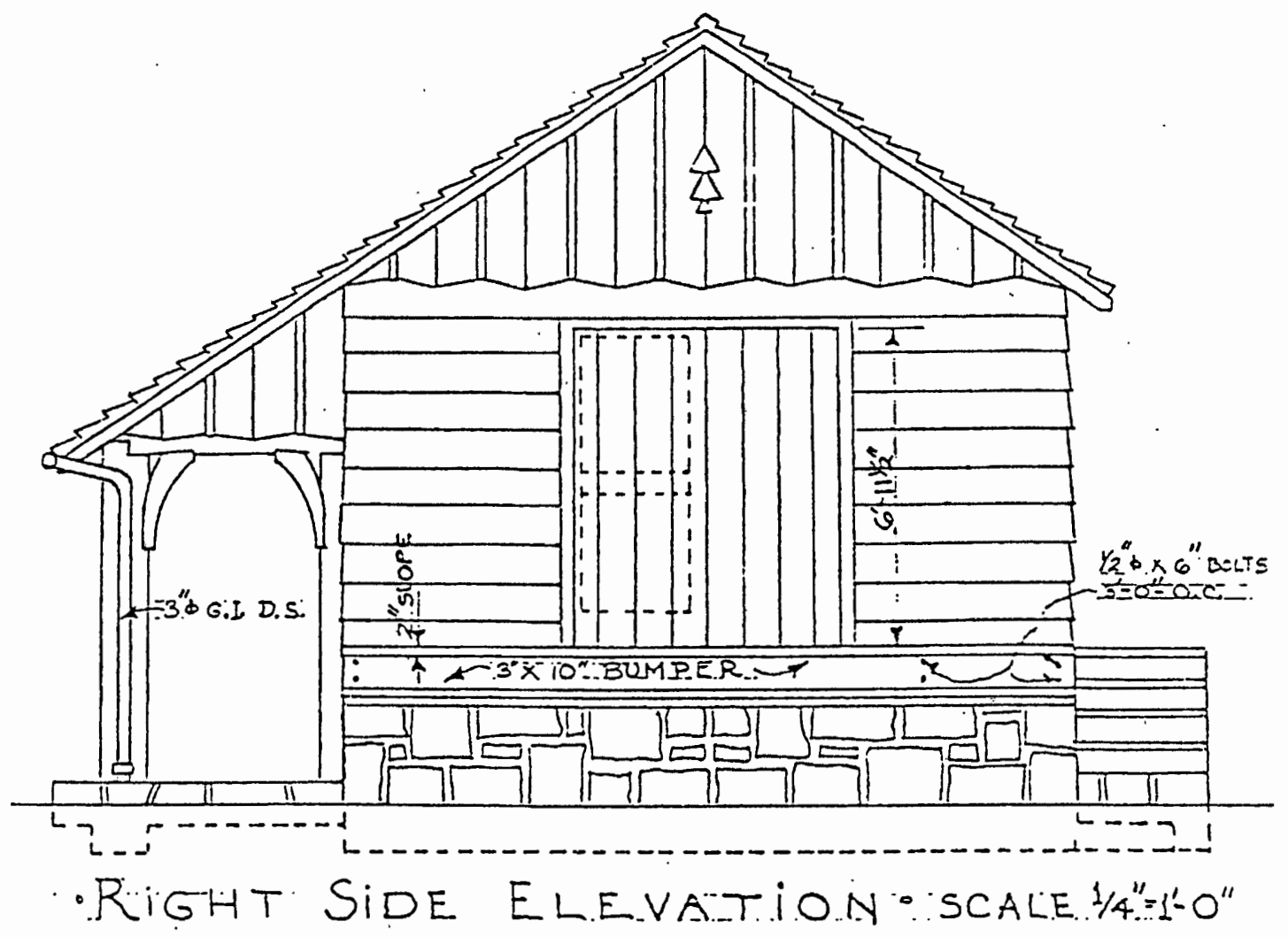

Figure 24. 